$$
\begin{aligned}
& \text { UNIVERSIDADE DE BRASÍLIA - UnB } \\
& \text { INSTITUTO DE LETRAS - IL }
\end{aligned}
$$

DEPARTAMENTO DE LÍNGUAS ESTRANGEIRAS E TRADUÇÃO - LET PROGRAMA DE PÓS-GRADUAÇÃO EM ESTUDOS DA TRADUÇÃO POSTRAD

\title{
A TRADUÇÃO DO EU E DO OUTRO: IDENTIDADES ALTERADAS PELA LÍNGUA-CULTURA BRASILEIRA
}

DANIEL FREITAS FERREIRA

ORIENTADOR: JULIO CESAR NEVES MONTEIRO

DISSERTAÇÃO DE MESTRADO EM ESTUDOS DA TRADUÇÃO

BRASÍLIA/DF

MARÇO/2016 


\section{REFERÊNCIA BIBLIOGRÁFICA E CATALOGAÇÃO}

FERREIRA, Daniel Freitas. A tradução do eu e do outro: identidades alteradas pela língua-cultura brasileira. Brasília: Departamento de Línguas Estrangeiras e Tradução, Universidade de Brasília, 2016,

140 f. Dissertação de mestrado em Estudos da Tradução.

Documento formal, autorizando reprodução desta dissertação de mestrado para empréstimo ou comercialização, exclusivamente para fins acadêmicos, foi passado pelo autor à Universidade de Brasília e acha-se arquivado na Secretaria do Programa. O autor reserva para si os outros direitos autorais, de publicação. Nenhuma parte desta dissertação de mestrado pode ser reproduzida sem a autorização por escrito do autor. Citações são estimuladas, desde que citada a fonte.

\section{FICHA CATALOGRÁFICA}

\section{FERREIRA, Daniel Freitas.}

"A tradução do eu e do outro: identidades alteradas pela língua-cultura brasileira" Daniel Freitas Ferreira - Brasília: UnB, IL, LET, POSTRAD, 2016.

$140 \mathrm{f}$.

Dissertação de mestrado - Programa de Pós-Graduação em Estudos da Tradução (POSTRAD) do Departamento de Línguas Estrangeiras e Tradução (LET) da Universidade de Brasília (UnB).

Orientador : Julio Cesar Neves Monteiro.

1. Tradução. 2. Identidade. 3. Alteridade

I. Universidade de Brasília . II. A tradução do eu e do outro: identidades alteradas pela língua-cultura brasileira. 
UNIVERSIDADE DE BRASÍLIA

INSTITUTO DE LETRAS - IL

DEPARTAMENTO DE LÍNGUAS ESTRANGEIRAS E TRADUÇÃO - LET PROGRAMA DE PÓS-GRADUAÇÃO EM ESTUDOS DA TRADUÇÃO POSTRAD

\section{A TRADUÇÃO DO EU E DO OUTRO: IDENTIDADES} ALTERADAS PELA LÍNGUA-CULTURA BRASILEIRA

DANIEL FREITAS FERREIRA

DISSERTAÇÃO DE MESTRADO SUBMETIDA AO PROGRAMA DE PÓS-GRADUAÇÃO EM ESTUDOS DA TRADUÇÃO, COMO PARTE DOS REQUISITOS NECESSÁRIOS À OBTENÇÃO DO GRAU DE MESTRE EM ESTUDOS DA TRADUÇÃO.

APROVADA POR:

$\overline{\text { Prof. Dr. JULIO CESAR NEVES MONTEIRO (UnB) }}$

(ORIENTADOR)

Prof $^{\text {a }}$. Dra ${ }^{\mathrm{a}}$. SABINE GOROVITZ (UnB)

(EXAMINADORA INTERNA)

Prof. Dr. WALTER CARLOS COSTA (UFSC)

(EXAMINADOR EXTERNO)

BRASÍLIA/DF, 29 de março de 2016 


\section{AGRADECIMENTOS}

Durante esta caminhada, por vezes desacreditada e incompreendida, diversas pessoas me ajudaram de forma direta e indireta a alcançar o objetivo de finalizar este trabalho da melhor forma possível. Dentre os apoios mais diretos, sem os quais talvez não estivesse aqui hoje com esta dissertação concluída, gostaria de citar algumas pessoas.

Primeiramente, agradeço à minha família, meu pai, minha mãe, meus irmãos, por estarem sempre presentes e me incentivando a continuar com este objetivo traçado na minha vida.

Agradeço de forma especial à minha noiva, Taísa, que esteve ao meu lado durante esses dois anos, aguentando todas as minhas crises acadêmicas e pessoais, e me incentivando a terminar a pesquisa da melhor maneira.

Agradeço ao meu orientador, professor Julio, por toda a ajuda, paciência, atenção, dedicação e por acreditar em mim durante todo o trabalho.

Agradeço, com especial carinho, à professora Alba Escalante, que tem sido uma inspiração e uma ajuda sempre presente dentro e fora da academia.

À minha cunhada, Tatiane, por ler e revisar meu trabalho com tanto carinho, adicionando novas ideias e sugestões.

À professora Alessandra, que esteve na minha qualificação e leu de forma minuciosa e atenta meu trabalho, e pôde acrescentar diversas sugestões para o resultado final.

Aos companheiros do mestrado, com os quais pude compartilhar ótimos momentos e criar laços que, com certeza, levaremos para toda a vida.

A todos envolvidos no Programa de Pós-Graduação em Estudos da Tradução. A todos os professores do POSTRAD, que fizeram parte desse processo de constante aprendizado, e que me ajudaram e me inspiraram tanto. Assim como às secretarias, sempre dispostas a ajudar.

Aos participantes das entrevistas, que com suas ajudas e amizades tornaram melhor o presente trabalho.

Por fim, agradeço à CAPES, por me proporcionar a oportunidade de ser bolsista e poder me dedicar a esta pesquisa. 
Aprender uma língua é sempre, um pouco, tornar-se um outro.

Christine Revuz 


\section{RESUMO}

\section{A TRADUÇÃO DO EU E DO OUTRO: IDENTIDADES “ALTERADAS” PELA LÍNGUA-CULTURA BRASILEIRA}

Parto do princípio que nosso discurso não é nosso, é parte de um discurso que é definido por outros. Somos sujeitos historicamente situados e, por isso, temos discursos diferentes inclusive dentro da nossa própria língua, dependendo da situação. E isso se intensifica na língua estrangeira. As formas de construção das frases não nos remetem às mesmas heranças culturais; assim como as conotações e denotações da língua materna flutuam, de certo modo, entre os signos, as frases e as sequências. Destaco que quando falamos em tradução vamos muito além do conhecimento linguístico ou de uma transferência de um texto em uma língua $\mathrm{A}$ para uma língua $\mathrm{B}$, pois devemos pensar em ressignificação do sujeito em uma nova língua-cultura e, dessa forma, atentar-nos para fatores históricos, geográficos, políticos, interesses geopolíticos, questões éticas, respeito à alteridade. Além disso, os Estudos da Tradução também abordam as formações de identidades que atravessam as fronteiras naturais e têm que negociar com as novas culturas em que vivem, sem simplesmente serem aceitas completamente ou sem perderem completamente suas características de origem, elas carregam os traços das culturas, das tradições, das linguagens e das histórias particulares. A diferença é que elas não são e nunca serão unificadas, pois são o produto de várias histórias e culturas interconectadas, pois estão traduzidas. Dessa forma, o presente trabalho busca discutir a tradução como prática discursiva e social, e seu papel na formação da identidade do sujeito em contexto de aprendizagem de português como segunda língua, buscando apontar que o discurso não é espelhado entre as línguas, e a partir do discurso dos Estudos da Tradução, pretendo romper com a ideia de que a tradução é apenas uma atividade mecânica de passagem de conteúdos de uma língua para outra e apresento-a como uma complexa prática discursiva e social. E dentro do par linguístico que trabalho, questiono a ideia corrente de proximidade entre português e espanhol como uma facilidade tradutória.

Palavras-chave: tradução; alteridade; identidade 


\section{ABSTRACT \\ THE TRANSLATION OF THE SELF AND THE OTHER: IDENTITIES MODIFIED BY THE BRAZILIAN LANGUAGE-CULTURE}

I start from the premise that our speech is not ours; it is part of a speech which is defined by others. We are historically located individuals; therefore, we have different speeches even in our own language depending on the situation. This is intensified in a foreign language. Sentence construction does not allude to the same cultural heritage. In a certain way, connotations and denotations in the mother tongue flow among signs, sentences and sequences. I emphasize that when we talk about translation we go beyond the linguistic knowledge or a text transfer of language A to language B, for we should think about the re-signification of the individual in a new language-culture; thus be attentive to historical, geographical, and political factors, geopolitical interests, ethical issues, for they point out to otherness. Furthermore, Translation Studies also approach identity formations of individuals crossing natural borders that have to bargain with the new cultures they live in - without simply being completely accepted or without completely losing their original characteristics. They carry their own cultural features, traditions, languages and stories. The difference is that they are not and will never be unified since they are the product of several interwoven stories and cultures: they are translated individuals. Thereby, this present study seeks to discuss translation as a discursive and social practice, its role in identity formation of individuals within the Portuguese as a second language learning environment, highlight that speech is not reflected between languages; and from the Translation Studies perspective, I intend to break from the idea that translation is only a mechanical activity of transferring content from one language into another. I present it as a complex discursive and social practice. Also, from the standpoint of the language pair I work with, I question the current idea of proximity between Portuguese and Spanish as being a translational facility.

Keywords: Translation; otherness; identity. 


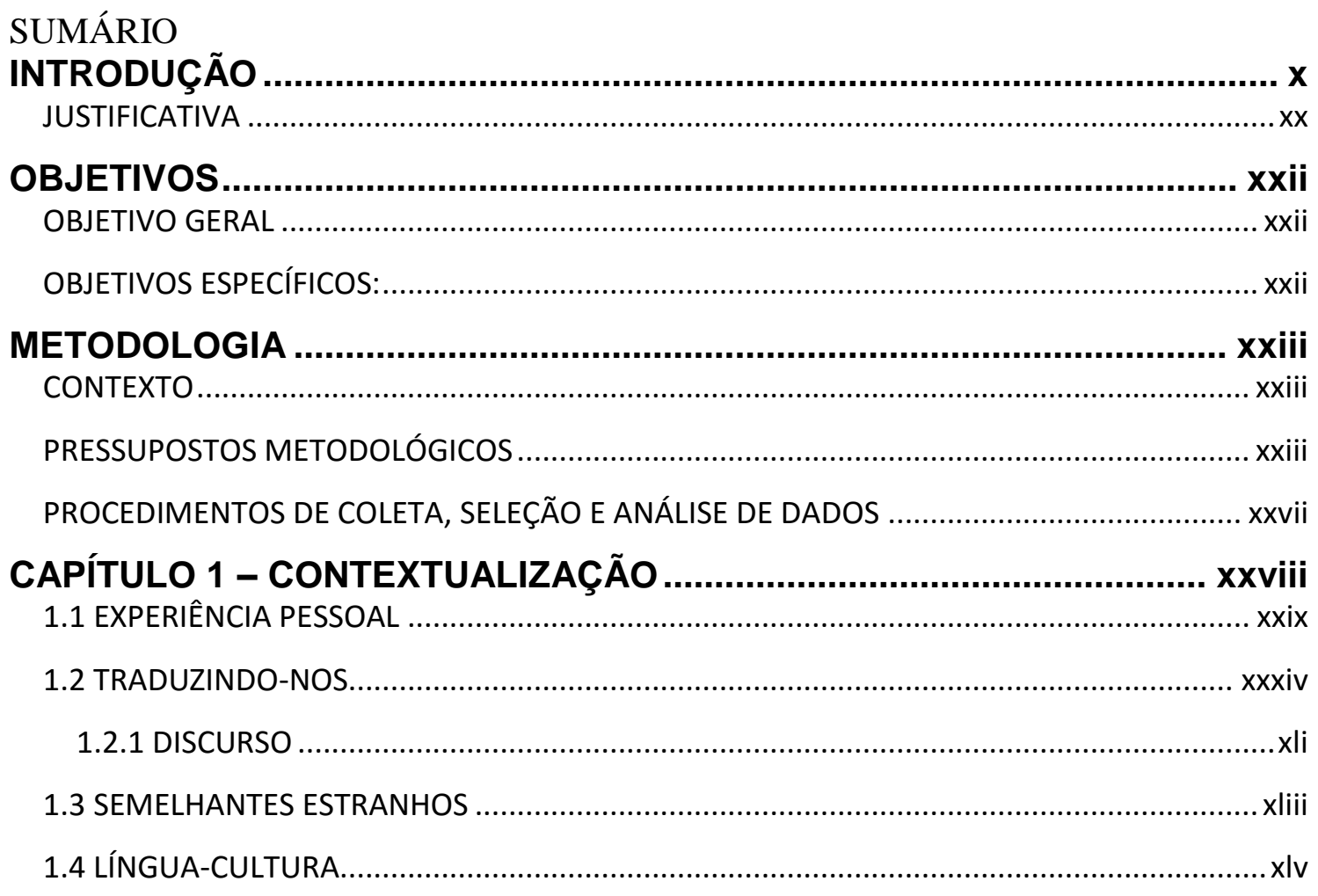

CAPÍTULO 2 - ALTERIDADE E IDENTIDADE........................................... I

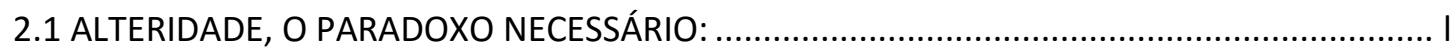

2.2 TRADUZINDO A IDENTIDADE:..................................................................................

CAPÍTULO 3 - IDENTIDADES ALTERADAS........................................ Ixxiii

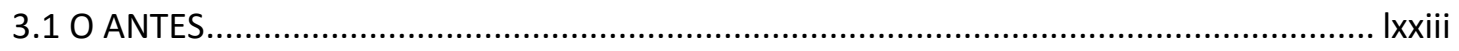

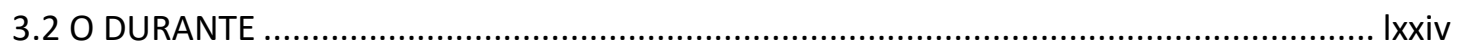

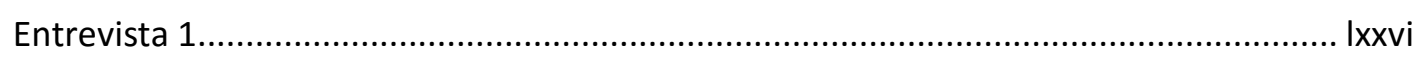

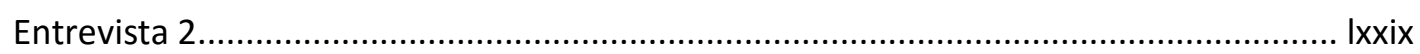

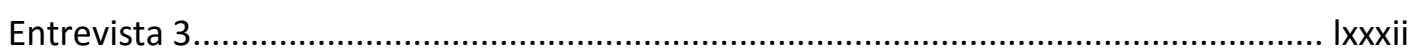

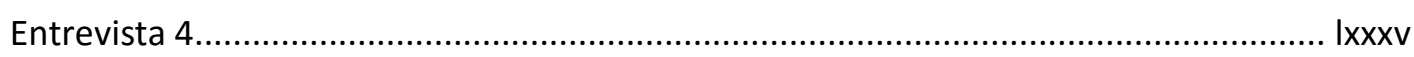

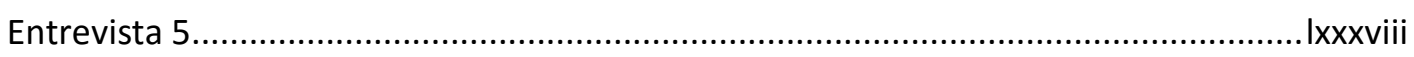

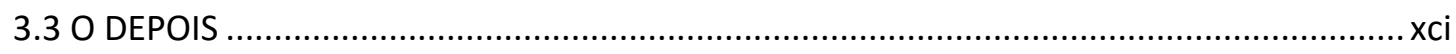

CONCLUSÃO .................................................................................... xcvii

REFERÊNCIAS ............................................................................. cii

ANEXO A - TRANSCRIÇÕES DAS ENTREVISTAS ............................... cvii

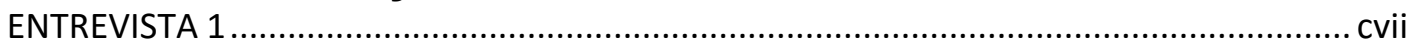

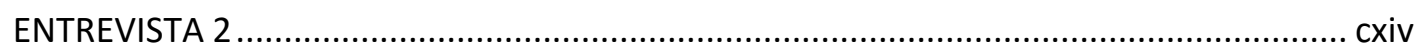

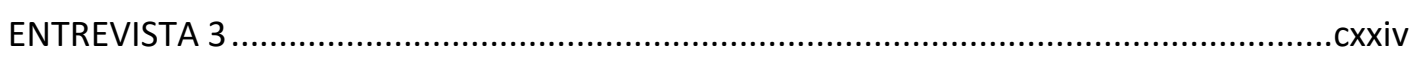

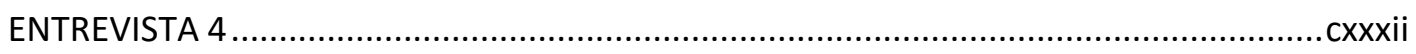

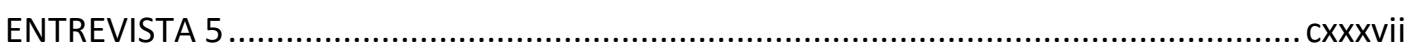




\section{INTRODUÇÃO}

A presente pesquisa teve sua gênese numa inquietação minha ao trabalhar como tradutor do par linguístico português-espanhol e como professor de português para falantes de espanhol. Com esses ofícios, senti a necessidade de entender melhor a relação que existe entre o indivíduo e as línguas que fala. Para tratar desse tema tão complexo, contudo ainda pouco explorado dentro dos estudos da tradução, optei por destacar o processo de formação de identidades a partir da análise de como os indivíduos lidam com a alteridade em contexto de aprendizagem de outro idioma (no caso, o português brasileiro).

Desta forma, podemos entender o título do trabalho, o qual explica os principais pontos da pesquisa. Ao usar os termos "eu" e "outro", refiro-me também à "identidade" e à "alteridade" com que temos de lidar, consciente ou inconscientemente, quando falamos ou aprendemos uma língua diferente da nossa língua primeira. Importa pontuar, também, que tal alteridade, presente nesse processo de aprendizado e de aceitação de mim mesmo e dos outros a minha volta, acaba por alterar nossas identidades. Nesse sentido, o ambiente de ensino-aprendizagem é reconhecido como um contexto profícuo para trocas e relações que extrapolam o mero compartilhar de aspectos técnicos, gramaticais, sintáticos, lexicais.

No caso específico desta pesquisa, trabalho com estrangeiros que vieram viver no Brasil e aprenderam a língua-cultura brasileira. E quando uso o termo língua-cultura, o faço no intuito de destacar minha visão de língua e cultura como algo intrinsecamente ligado. Acredito que o sistema de significação é socialmente estabelecido, e é por meio dele que vemos o mundo e o constituímos. Bakhtin destaca esse caráter interacional e sociocultural da linguagem como essencial: "Todas as esferas da atividade humana, por mais variadas que sejam, estão sempre relacionadas com a utilização da língua." (BAKHTIN, 1997, p. 179).

Segundo Carmen Rosa Caldas-Coulthard, um dos teóricos russos também participantes da escola teórica de Bakhtin, Valentin Voloshinov, propôs que "a forma dos signos deve ser condicionada pela organização social das pessoas envolvidas e pelas condições de suas interações" (CALDAS-COULTHARD, 2008, p. 23).

A autora defende que o trabalho desse teórico tem importância ao conectar “ [...] o estudo da linguagem e da semiótica com o estudo da ideologia. Para Voloshinov, a 
dimensão social é essencial para qualquer análise semiótica" (CALDAS-COULTHARD, 2008, p. 24), ou seja, para qualquer análise que se debruce sobre os diversos sistemas de significação que compartilhamos - entre eles, a língua. Ela segue, retomando o autor:

1 - A ideologia não pode ser divorciada da realidade material do signo.

2 - Os signos não podem ser divorciados das formas concretas da interação social (sendo o signo parte da interação social organizada, não pode existir fora dela).

3 - As comunicações e as formas de comunicação não podem ser divorciadas das bases materiais. (VOLOSHINOV, 1973, p. 21, apud CALDASCOULTHARD, 2008, p. 23)

Os valores e as ideias compartilhadas entre os falantes de determinada língua são regras apropriadas a uma situação específica, pois temos um determinado discurso dependendo do contexto em que estamos inseridos. Dessa maneira, não há como falar de um sem o outro, isto é, sempre que me referir à língua ou à cultura, parto do pressuposto de que os dois são indissociáveis, apesar de poder destacar um ou outro de forma mais específica no decorrer do trabalho. A cultura, como acervo material e imaterial de conhecimentos, práticas, saberes, instrumentos, visões de mundo, formas de significação e interação dos grupos humanos entre si e entre os elementos não-humanos circundantes, pode ser considerada o alimento da "base material" das relações sociais.

É a partir desse prisma que proponho refletir sobre um objeto complexo e de grande relevância, que é uma teorização sobre o processo tradutório do sujeito. Os Estudos da Tradução têm se ocupado dos grandes sistemas literários, das interfaces entre tradução e tecnologia, ou ainda das relações entre nações e/ou etnias, configurando-se como um campo teórico e de investigação sobre aspectos macro-políticos, com ênfase nas questões de ideologia:

\begin{abstract}
Algumas das discussões mais reveladoras sobre tradução na última década focaram nas questões de ideologia. De fato, tem ocorrido um diálogo acadêmico produtivo que se prolonga por anos sobre as várias facetas do assunto com contribuições de pessoas de todo o mundo. Despertadas principalmente por aqueles que se dedicam ao engajamento social, questões sobre o tradutor enquanto agente ético de mudança social foram a essência da prática e da teoria da tradução. (TYMOCZKO, 2013, p. 115).
\end{abstract}

Assim, um estudo que se proponha a investigar de que forma a subjetividade e a interpessoalidade se articulam enquanto campo de processos tradutórios complexos pode ventilar a disciplina, ampliando seus horizontes teóricos pelo fornecimento de mais informações a aspectos ainda pouco abordados ou estigmatizados

Esta investigação, dedicada a aprofundar-se sobre pessoas como nós, que aprendem outras línguas, com diferentes propósitos, histórias, culturas, têm algo em 
comum. Esse algo compartilhado seria propriamente a forma com que, durante o processo de ensino e aprendizagem de um novo idioma, os sujeitos alimentam sua intersubjetividade pela criação e pela mudança de suas próprias identidades. Interessa, ainda, discutir sobre a necessidade em se lidar com a alteridade, tanto do outro como de nós mesmos, estar relacionada a processos tradutórios.

Sandra Bermann aponta que "[...] o papel como entidade cultural e também linguística [da linguagem e da tradução] está apenas começando a ser teorizado" (BERMANN; 2005, p. 2, tradução minha ${ }^{1}$ ). Para a autora, o contexto das identidades culturais nacionais é propício a um pensar de linguagem e tradução enquanto espaço de uma dialética da alteridade:

O papel da linguagem no processo de nacionalidade é ao mesmo tempo poderoso e complexo. Como um meio de comunicação que é notadamente atado ao povo (a noção de pertencimento "nós-criando" invocada em descrições essencialistas da nação), a linguagem sempre foi uma característica definidora da identidade nacional, mesmo - especialmente - quando essa "nação" se tornou diaspórica. Tampouco a linguagem é um elemento neutro. Consciente ou inconscientemente, ela performa proezas hábeis de apropriação e exclusão, sustentadas por uma dialética da alteridade. Criando e dependendo de noções de diferença cultural, grupos enfatizam nosso "nós", nossa identidade e nossa solidariedade. (BERMANN, 2005, p. 3, tradução minhaª).

É bem verdade que vivemos um processo de ampliação das fronteiras dos Estudos da Tradução - correlato aos simultâneos recrudescimento e dissolução de fronteiras nacionais, culturais, econômicas, políticas, étnicas, ou seja, estamos em um momento global específico que marca a tradução e por ela é marcado: "Em um mundo com transformações populacionais e tecnológicas velozes, em que linguagem e cidadania são capturadas em redes firmemente tecidas de poder econômico, militar e cultural, linguagem e tradução operam em cada conjuntura" (BERMANN, 2005, p. 1, tradução $\left.\operatorname{minha}{ }^{3}\right)$.

Dessa forma, devemos expandir nossos horizontes como pesquisadores da área. Por isso, o presente trabalho tem o intuito de aprimorar e ampliar o campo de pesquisa

\footnotetext{
1 "[...] their role as cultural as well as linguistic entities is only beginning to be theorized."

2 "The role of language in the process of nationhood is both powerful and complex. As a means of communication that is notably tied to the demos (the 'we-creating' sense of belonging invoked in essentialist descriptions of the nation) language has always been a defining feature of national identity, even - specially - when this 'nation' has become diasporic. Nor is language a neutral element. Consciously or unconsiously, it performs deft feats of appropriation and exclusion, supported by a dialetic of otherness. Creating and relying upon notions of cultural difference, groups underscore our 'we', our identity and our solidarity."

3 "In a world of rapidly transforming populations and technologies, where language and citizenship are caught up in tightly woven webs of economic, military, and cultural power, language and translation operate at every juncture."
} 
dos Estudos da Tradução. Habitualmente, a tradução tem sido vista como materialização de um texto numa língua A em língua B: "Há pelo menos 25 anos tem se aceitado que a tradução é um texto sobre um texto ou, em outras palavras, uma forma de 'metaenunciado'.” (TYMOCZKO, 2013, p. 116). Para a autora, essa observação "aparentemente inócua" deve ser colocada num contexto ideológico, discursivo; assim é possível reconhecer a complexidade da ideologia da tradução - e da tradução como ferramenta ideológica.

Por isso, aposto na concepção de tradução como um termo mais abrangente, o qual nos permite levantar importantes conceitos tradutológicos, como alteridade e identidade, a partir da perspectiva de sujeitos em situação de imersão num contexto de tradução, superando e transferindo o foco da tradução vista como mera transferência textual para uma operação linguística permeada de processos ideológicos que estão no plano macro-político, das identidades nacionais, por exemplo, e também subjetivo, em que importam as elaborações subjetivas de identidades e/ou alteridades em contato a partir do contexto de ensino-aprendizagem de idiomas.

A linguagem tem a função de nos ajudar a enxergar o mundo, o outro e a nós mesmos. Por meio dela, conseguimos atribuir sentidos ao que somos e ao que está ao nosso redor. É também por meio do uso da linguagem que conhecemos a realidade, e a construímos, bem como constituímos nosso senso de coletividade, cultura, nação:

\begin{abstract}
[...] os sujeitos agora reconhecem a si mesmos e a seus interesses na abstração do estado soberano por afiliações de, entre outras, fãs de esportes, amantes de música, leitores de ficção ou falantes de uma língua. Pois a língua, de fato, é um dos mais importantes modos representacionais do social enquanto artefato cultural. [...] As línguas podem separar e excluir, tão prontamente quanto conectam e incluem. A linguagem nunca é neutra nem completa, mas aberta às forças históricas e à reformulação "dialógica" desde perspectivas agônicas [...] numa luta infindável entre posições sócio-políticas diferenciadas, assimétricas com relação ao poder. (GODARD, 2005, p. 250, tradução minha ${ }^{4}$ ).
\end{abstract}

Analisar em que medida a linguagem e a tradução se relacionam com a constituição do sujeito, expresso a partir da identidade e da alteridade, é a abordagem que proponho com essa pesquisa. A partir disso, poderemos perceber que o processo e o produto da tradução, uma prática dinâmica e complexa que se dá em vários níveis da e na

\footnotetext{
4 "[...] subjects now recognize themselves and their interests in the abstraction of the sovereign state through affiliations as, among other things, sports fans, music lovers, fiction readers or speakers of a language. For language indeed is one of the most important representational modes of the social as cultural artefact. [...] Languages may separate and exclude, as readily as they link and include. Language is never neutral or complete but open to historical forces and 'dialogic' reworking from agonistic perspectives [...] in an unending struggle between differentiated socio-political positions asymmetrical in respect to power."
} 
linguagem, são resultados de diversos fatores e, dentre eles, está o sujeito que traduz, o qual acredito ser o maior determinante dessa relação. Acredito ainda que é a tradução que apresenta o "outro" em sua forma mais radical e diferente: a linguagem.

E quando penso em uma linguagem diferente, concebo imediatamente uma outra maneira de sentir, pensar e perceber o mundo ao meu redor. Por isso, os termos L1/L2 ou Língua de partida / Língua de chegada - não me agradam, uma vez que anulam a relação existente entre o sujeito que traduz com as línguas em contato. Gosto mais dos termos Língua primeira / Língua estrangeira; ou simplesmente Tradução / Versão, os quais explicitam a relação sujeito-língua, deixando aparecer em qual língua o sujeito se sente mais cômodo e com qual estabelece maior ou menor vínculo.

A tradução pode ser importante ferramenta à contribuição de uma maior proximidade entre os povos e, desdobrando esse sistema de aproximação/reflexão, podemos também propor que ao lidarmos com a cultura do outro, somos levados a refletir sobre a nossa. Ao abordar o termo "tradução" devemos salientar que não trabalhamos com sistemas fechados, mas sim com línguas-culturas, algo dinâmico, em constante construção, dado que nos ressignificamos inclusive dentro da nossa própria língua. Esta não é hermética e muda todos os dias, com palavras novas, com incorporação de expressões, e apagando palavras já não mais usadas. A lingua, conforme Blecua (1979), apresenta um aspecto paradoxal: "é um sistema de regras, unidades e valores utilizado por uma comunidade, e como tal apresenta um caráter fixo, estável, mas - ao mesmo tempo - a lingua evolui, adquire novos elementos, novas regras, ou elimina outras." (BLECUA, 1979, p. 27).

Um exemplo dessa realidade mutável e cotidiana da linguagem está no fato de ser muito comum, quando passamos um tempo fora do nosso país e voltamos, que percebamos algumas palavras e expressões novas, as quais não estavam em voga antes, pois dependem do uso cotidiano que as pessoas fazem delas. Blecua estabelece uma relação entre semântica e sociedade ao definir que "as palavras funcionam como elementos de um código dentro de uma comunidade, e, portanto, refletem em muitos casos os costumes, superstições, crenças religiosas, ou, simplesmente, a cultura material da comunidade que fala essa língua.” (BLECUA, 1979, p. 28).

Os próprios sujeitos se constituem através da linguagem. Barbara Godard explora essa possibilidade ao teorizar sobre os discursos feministas:

Como uma prática emancipatória, o discurso feminista é um discurso político dirigido em direção à construção de novos sentidos, e é focado nos sujeitos 
tornando-se em/pela linguagem. Ele busca expor os modos ideológicos de percepção através de uma expansão das mensagens nas quais experiências individuais e coletivas originam-se de uma postura crítica contra os contextos sociais do patriarcado e sua linguagem. (GODARD, 1989, p. 44, tradução minha ${ }^{5}$.

A realidade de constante contato com as línguas nos leva a mudar nossa própria identidade, e traz consigo um desenvolvimento do processo de aceitação da alteridade, daquilo que é outro, diferente do que estamos acostumados a vivenciar, e temos que perceber que o extraordinário só existe em relação a mim, aos meus padrões, pois a partir do momento em que faço parte de uma comunidade, os eventos não são mais estranhos. A minha formação é que me leva a criar estranhamentos ou não. Tudo isso é tradução. Tradução de si mesmo, tradução do outro, do meio a nossa volta. E todos estes fatores influenciam em como aprendo e apreendo uma nova língua-cultura, assim como a forma com que irei transportar para outros minha língua primeira.

Outra condição relevante é a das línguas ditas próximas, como, por exemplo, o português e o espanhol, que poderiam ser pensadas como línguas mais fáceis de traduzirse entre elas. Todavia existe uma abundância de elementos que devem ser levados em consideração no momento em que se traduz, visto que não devemos restringir uma língua apenas às suas palavras, como se fosse um sistema estanque. As línguas são vivas, dependem da entonação do sujeito, do ritmo, das pausas, dos silêncios, das formas como nos portamos, da nossa profissão, da família, dos anseios, dos meios onde vivemos, do nosso humor e dos outros com quem estamos lidando, do conhecimento de fatos históricos, políticos, econômicos, culturais, de heranças que construímos desde nossos berços, muitas vezes de forma inconsciente. A língua é o uso que fazemos dela, e a tradução é a língua em uso. Para Cronin, ela é uma tecnologia da linguagem que reflete todo esse grande processo paradoxal de comunidade e diferenciação:

[...] a tradução, enquanto atividade humana, é, inescapavelmente, uma tecnologia. A presença da techné na pintura de Brueghel da torre de babel não é acidental. Sua presença não elimina, mas obscurece a diferenciação. Não é porque usamos as mesmas ferramentas (manuais, digitais) que iremos sair por aí fazendo as mesmas coisas. Pelo contrário, fazemos coisas completamente diferentes, e essa diferença nos garante a humanidade das coisas que fazemos. (CRONIN, 2013, p. 218).

\footnotetext{
5 "As an emancipatory practice, feminist discourse is a political discourse directed towards the construction of new meanings and is focused on subjects becoming in/by language. It seeks to expose ideological modes of perception through an expansion of messages in which individual and collective experience originate from a critical stance against the social contexts of patriarchy and its language."
} 
Dessa maneira, gostaria de levantar uma questão que nos propõe Urgese (1989): "será que é possível ignorar nosso modo de pensar e nosso modo de ver o mundo, simplesmente por estarmos falando outra língua?” Acredito que não começamos a pensar noutra língua apenas por tomar algumas aulas de um idioma estrangeiro; senão reduziríamos a língua a uma mera lista de palavras.

Além disso, a tradução é uma atividade que não controlamos quando estamos aprendendo e utilizando uma nova língua, é algo inconsciente, pois, se aprendemos uma segunda língua (L2) ${ }^{6}$, é porque já possuímos uma língua primeira, e tentamos encontrar lógica naquela língua desconhecida baseados no nosso conhecimento anterior. A relação que temos com nossa língua primeira, e a proximidade que nossa língua primeira tem com a língua estrangeira que aprendemos, são fatores que irão influenciar o nosso aprendizado.

Assim, vistas pelas suas interfaces culturais, as línguas se integram aos diferentes universos linguísticos, ampliando a visão de mundo que eles transmitem. Ademais, se considerarmos, por exemplo, o contexto de aprendizagem de uma língua estrangeira, é claro que esta passa necessariamente pelo filtro da língua primeira. Além disso, essa prática também proporciona uma reflexão enriquecedora sobre mecanismos $\mathrm{e}$ peculiaridades da nossa própria língua.

Segundo Revuz, “a língua estrangeira é, por definição, uma segunda língua, aprendida depois e tendo como referência uma primeira língua, aquela da primeira infância" (REVUZ, 2001, p. 215). Um árabe, por exemplo, tem dificuldades para aprender o português que são diferentes das de um falante de espanhol, pois a comparação com a língua primeira ou dominante, processo que Zurrita Navarrete chama de "tradução interiorizada", é inevitável. Como propõe essa autora, "nos níveis iniciais, a tradução interiorizada ocorre em quase todos os momentos, pois o aluno traduz tudo ou quase tudo." (NAVARRETE, 1997, p. 137).

Além disso, existe uma ideia restrita do que seja tradução. Segundo Widdowson (1979, p. 107, tradução minha $)$ : “As objeções ao uso da tradução geralmente parecem

\footnotetext{
${ }^{6}$ Para o presente trabalho, o termo Segunda Língua será aplicado para descrever uma língua diferente da primeira língua, mas que passa a ocupar um papel preponderante na vida do falante, uma vez que suas operações intelectuais passam a ser desenvolvidas nessa língua, além da comunicação do dia a dia. É o caso dos estrangeiros que vêm morar no Brasil e aprendem o português em situação de imersão, diferentemente da situação de pessoas que aprendem o português nos seus países de origem, que pode ser em situação de Língua Estrangeira ou Língua de Herança.

7 "The objections to use of translation seem generally to be based on the assumption that it must necessarily involve establishing structural equivalence."
} 
basear-se no pressuposto de que ela deve, necessariamente, estabelecer uma equivalência estrutural".

Revuz (2011) nos faz refletir sobre a habilidade de aprender a falar de forma tão fácil quando somos crianças, mas de maneira tão difícil quando aprendemos outra língua ao crescermos, mesmo com uma enorme quantidade de saberes e de instrumentos intelectuais. Nesse sentido, o autor propõe que a primeira língua é tão onipresente na vida do sujeito que ele tem o sentimento de jamais tê-la aprendido, e o encontro com outra língua aparece como uma experiência totalmente nova. Por isso, há correntes que buscam aproximar o ensino-aprendizagem de uma segunda língua ao da primeira, com a ideia de que na infância se assimila muito facilmente a língua por imersão - na verdade, trata-se de uma tentativa, absolutamente imaginária, de voltar às origens.

Cabe também destacar que aprender uma língua é um objeto de investimento forte, frequentemente passional. Além disso, como um objeto de conhecimento intelectual, a língua também é objeto de uma prática complexa. Tal prática inclui o sujeito, seu modo de relacionar-se com os outros e com o mundo, assim como sua prática corporal e todo seu aparelho fonador. Como destaca Revuz:

Sem dúvida, temos aí uma das pistas que permitem compreender por que é tão difícil aprender uma língua estrangeira. O sujeito deve pôr a serviço da expressão de seu "eu" um vaivém que requer muita flexibilidade psíquica entre um trabalho de corpo sobre os ritmos, os sons, as curvas entoacionais, e um trabalho de análise e de memorização das estruturas linguísticas. É possível se levantar a hipótese de que muitos dos insucessos podem ser analisados como uma incapacidade de ligar essas três dimensões: afirmação do "eu", trabalho do corpo, dimensão cognitiva. (REVUZ, 2011, p. 216-217).

A relação entre as línguas é também tradução, comparação, confronto. A tradução é a formação de uma identidade híbrida, que ocorre no discurso. Pensar discurso é pensar aquela já explicitada dimensão eminentemente social, interativa, cultural da linguagem. Para Caldas-Coulthard,

Quando falamos de discurso (no singular) referimo-nos aos textos e gêneros em seus contextos sociais, quer dizer, não estamos considerando apenas o texto e sua estrutura, mas também como ele se relaciona com a sociedade e com a cultura à qual pertence. Quando estudamos o discurso, estudamos a maneira pela qual um texto cria sentidos e reflete a visão e a ideologia de seus escritores e da sociedade à qual pertence. [...] Nesse sentido, o discurso é sempre parte da ação social. (CALDAS-COULTHARD, 2008, p. 36).

É dessa análise de texto e linguagem como discurso que entendo a tradução, uma prática social, que se dá no encontro de sujeitos, de textos, de mundos, de ideologias. A tradução propicia o acesso a outras leituras de mundo, além de desenvolver a rede de intertextualidade, de interdisciplinaridade e de interculturalidade entre os povos. 
As línguas não são diferentes apenas pela sua maneira de recortar o real, mas também pelo modo de recompô-lo no âmbito do discurso; nesse sentido, Ricoeur (2011) observa que a primeira unidade de linguagem significante é a frase e não a palavra. A frase organiza a relação entre um locutor, um interlocutor, uma mensagem que quer significar algo, e um referente, ou seja, aquilo sobre o que se fala. As frases são pequenos discursos retirados de discursos mais longos, de textos.

Os textos, por sua vez, fazem parte de conjuntos culturais através dos quais se exprimem visões de mundo diferentes, as quais, aliás, podem se confrontar no interior do mesmo sistema elementar de recorte fonológico, lexical, sintático. A tarefa do tradutor não vai da palavra à frase, ao texto, ao conjunto cultural, mas ao inverso: após profundas leituras de uma cultura, o tradutor passa do texto à frase e depois à palavra.

As diversas línguas tratam de maneira diferente a relação entre sentido e referente, a relação entre dizer o real e dizer outra coisa diferente do real, o possível, o irreal, a utopia, o indizível. Dessa forma, a presente pesquisa busca uma reflexão sobre aspectos funcionais, discursivos e culturais, e assim refletir a Tradução como contato de língua, como ressignificação linguística e social.

Para alcançar meus objetivos, primeiramente abordo questões relacionadas aos Estudos da Tradução. Assim, no primeiro capítulo, proponho uma contextualização do meu objeto, definição de termos utilizados no trabalho e uma explicação da origem da presente pesquisa, assim como o que irei desenvolver mais adiante.

No segundo capítulo, desenvolvo uma pequena revisão bibliográfica de autores que abordam os temas da identidade e alteridade e a relação com os Estudos da Tradução.

No terceiro capítulo pretendo mostrar o resultado das entrevistas feitas com estudantes de português brasileiro como segunda língua sobre o tema de sua constituição identitária relacionada aos processos de ensino-aprendizagem do novo idioma, e ainda, a relação na interface da tradução com esse processo de contato/confronto subjetivo e sócio-cultural. Nesse capítulo, com transcrições dos áudios e análise dos discursos dos aprendizes, pretendo realçar temas de interesse para a área de estudos da Tradução. 


\section{JUSTIFICATIVA}

Venho de uma formação no curso de Letras Tradução Espanhol que me fez descobrir a enorme abrangência do termo "tradução", assim como tal termo é presente em nossas vidas.

Agora, no Programa de Pós-Graduação em Estudos da Tradução da Universidade de Brasília, pude ampliar ainda mais meus horizontes na área, além de poder desenvolver uma pesquisa aproximando outra área, a qual veio tornar-se um ofício atualmente na minha vida, que é o ensino de português do Brasil para estrangeiros. Assim, por uma questão idiossincrática, não consigo deixar de perceber a grande relação entre os estudos da tradução e o aprendizado de línguas.

Ao trabalhar com o ensino de português do Brasil para falantes de espanhol no Núcleo de Ensino e Pesquisa em Português para Estrangeiros - o NEPPE, localizado aqui na Universidade de Brasília, tive o interesse de unir essas áreas com as quais estou em constante contato.

Uma das principais problemáticas da área da presente pesquisa é a crença existente no senso comum de que quando abordamos os temas "tradução" e "ensino de línguas", a primeira seria uma mera ferramenta em sala de aula. No entanto, discorrer e aprofundarse na área dos Estudos da Tradução permite romper com as crenças existentes. Tal crença acaba por provocar uma escassez de pesquisas na área, principalmente no caso de se pensar a tradução no contexto de ensino-aprendizagem de Português do Brasil como segunda língua, no qual os alunos estão imersos no nosso país e precisam de um uso imediato da língua-cultura, diferentemente de alunos que aprendem outro idioma nos seus países de origem.

Dessa maneira, mais adiante, abordarei alguns estudos contemporâneos na área de tradução, com o intuito de esclarecer a ampla área em que estamos imersos para que saiamos de uma visão restrita sobre o que é tradução. Isso porque parto da hipótese de que falar uma nova língua envolve a formação de novas identidades na língua-cultura em que estamos imersos, e é também um processo tradutório que ocorre conosco.

Optei por trabalhar com os falantes de espanhol, primeiramente, pela minha formação e também pela proximidade entre as línguas, que acaba por motivar uma crença de que o espanhol e o português, por serem línguas muito próximas, são muito simples de aprender entre os falantes deste par linguístico. Nesse contexto, gostaria de ressaltar 
os problemas da proximidade entre os idiomas, pois, além dos problemas meramente linguísticos, temos problemas na formação de discurso e de uma nova identidade na língua, ao aprender a ser outro em outro idioma, ou seja, aprender a se ressignificar.

Acredito que não é a questão da tipologia da língua que leva o aprendiz a ser outro em outra língua, pois temos discursos diferentes nos diferentes idiomas, uma vez que são diferentes discursos sociais em cada grupo social. O nosso discurso não é nosso, é parte de um discurso que é definido por outros. Somos sujeitos historicamente situados, influenciados pela situação na qual aprendemos, pelo meio em que vivemos, pela razão pela qual estamos estudando, entre outros motivos:

O grupo social determina as práticas discursivas a que temos acesso. Gee (1990) sugere que todo grupo cultural tem seu próprio discurso, o qual é intrinsecamente ligado à maneira pela qual as pessoas se comportam e agem no mundo. Este discurso marca a identidade do grupo. No entanto, cada um de nós também faz parte de outros discursos - a escola, o trabalho, a igreja, os negócios, etc. São lugares onde discursos operam para integrar (ou não) as pessoas. Já que agimos em muitos lugares diferentes, as práticas discursivas representam as nossas várias identidades. (CALDAS-COULTHARD, 2008, p. $30)$.

Como explicitado no trecho acima, temos discursos diferentes inclusive na mesma língua, dependendo da situação. E isso se intensifica na língua estrangeira. Por exemplo: podemos querer nos expor mais ou menos no novo país ou no novo idioma, e isso não necessariamente tem relação com a proximidade entre as línguas. 


\section{OBJETIVOS}

\section{OBJETIVO GERAL}

Pesquisar o papel da tradução como prática discursiva e social, e seu papel na formação da identidade do sujeito em contexto de imersão na língua-cultura brasileira, buscando mostrar a tradução como um encontro entre línguas.

\section{OBJETIVOS ESPECÍFICOS:}

Apresentar argumentações, a partir do discurso dos Estudos da Tradução, sobre os desdobramentos que permitem sair da ideia de que a tradução é apenas uma atividade mecânica de passagem de conteúdo de uma língua para outra.

Questionar a ideia corrente de proximidade entre português e espanhol, mostrando que o discurso não é espelhado e que por isso não somos os mesmos sujeitos sociais nas duas línguas.

Descrever entrevistas com hispanofalantes, aprendizes de português, e como eles relacionam-se com a língua, com ênfase nas mudanças identitárias ocorridas por causa da imersão no Brasil. 


\section{METODOLOGIA}

\section{CONTEXTO}

É bem verdade que na sociedade ocidental em geral a expressão do "eu" é importante. Muitas vezes a identidade é até mais importante do que a sociedade. Contudo, há sociedades, como, por exemplo, algumas orientais, principalmente as que têm influência do pensamento confuciano, que têm uma percepção diferente da nossa, na qual a coletividade é superior ao indivíduo. Dessa maneira, gostaria de esclarecer a nãouniversalização do presente estudo em qualquer situação.

Partindo da hipótese de tradução como processo de ressignificação da identidade e formação do sujeito, faço um estudo com alunos hispano-falantes de português como segunda língua, para repensar alguns conceitos, como proximidade linguística. Para isso, defendo o papel da tradução não como ato mecânico nem favorecido pela proximidade entre as línguas, pois traduzir é uma atividade pragmática que trabalha com objetos vivos, as línguas em contato. Assim, me debruço, no caso dessa investigação, sobre a tradução de identidades mediada pela língua-cultura brasileira.

Ao fazer as entrevistas, meu interesse foi pesquisar a língua como uma realidade social e assim ver as como o aprendiz é nas duas línguas em contato, quais informações privilegia em detrimento de outras ao falar português, assim como suas dificuldades, os estranhamentos, a relação metafórica em ambas as línguas - espanhol e português brasileiro.

A realização das entrevistas foi, portanto, motivada por um desejo de analisar as questões subjetivas e sociais presentes nos relatos dos alunos que foram participantes nessa pesquisa. Parti da premissa de que em situação de imersão em outra língua os filtros do aluno são dissipados. Isso acontece de forma própria em cada situação social, pois os alunos aprendem dentro e fora de sala de aula. Na sala de aula existem certas censuras que não existem na rua, na televisão, na família.

\section{PRESSUPOSTOS METODOLÓGICOS}

A metodologia é definida como um caminho do pensamento e a prática exercida na abordagem da realidade, incluindo, simultaneamente, "a teoria da abordagem (o 
método), os instrumentos de operacionalização do conhecimento (as técnicas) e a criatividade do pesquisador (sua experiência, sua capacidade pessoal e sua sensibilidade)." (MINAYO, 2009, p. 14).

Como ressaltado pela própria autora, a metodologia não está restrita a técnicas, mas engloba concepções teóricas da abordagem e articula-se com a teoria, com a realidade empírica e com os pensamentos acerca da realidade.

A pesquisa, entendida como uma atividade fundamental da ciência, indaga sobre a realidade e também a constrói, tendo uma importância pedagógica fundamental: "é a pesquisa que alimenta a atividade de ensino e a atualiza frente à realidade do mundo" (MINAYO, 2009, p. 16). E mesmo que a pesquisa seja uma prática eminentemente teórica, ela vincula pensamento a ação. As indagações devem surgir de questões atinentes à vida real e ter como objetivo alguma reflexão e/ou prática sobre ela. Para Gil (2002), a pesquisa é um procedimento racional e sistemático que objetiva oferecer respostas a problemas propostos.

Gerhardt e Silveira (2009) tipificam a pesquisa quanto à abordagem (qualitativa ou quantitativa), quanto à natureza (pesquisa básica ou aplicada), quanto aos objetivos (exploratória, descritiva ou explicativa), e quanto aos procedimentos (pesquisa experimental; bibliográfica; documental; de campo; ex-post-facto; de levantamento; com survey; estudo de caso; participante; pesquisa-ação; etnográfica; etnometodológica).

A pesquisa de abordagem qualitativa propõe análise de dados que não podem ser quantificados, trabalhando, assim, "com o universo dos significados, dos motivos, das aspirações, das crenças, dos valores e das atitudes" (MINAYO, 2009, p. 21), fenômenos humanos que fazem parte da realidade social e relacional e dificilmente podem ser traduzidos na forma de números e indicadores quantitativos.

Minayo divide a pesquisa qualitativa nas etapas de 1) fase exploratória; 2) trabalho de campo; 3) análise e tratamento do material empírico e documental. A terceira etapa inclui ordenação e classificação dos dados, para que daí possa haver a realização da análise. O trabalho de campo aproxima o pesquisador da realidade social sobre a qual está investigando, e cria uma interação entre os sujeitos pesquisados e ele próprio (MINAYO, 2009, p. 61).

No caso da presente pesquisa, a abordagem qualitativa foi preponderante; quanto à natureza, a pesquisa é aplicada, porque “objetiva gerar conhecimentos para aplicação 
prática, dirigidos à solução de problemas específicos, e envolve verdades e interesses locais" (GERHARDT; SILVEIRA, 2009, p. 35).

Parto de uma noção mais abrangente de "problema" no que tange à sinonímia compartilhada, em contexto de pesquisa acadêmica, com o termo "questão", ou seja, parafraseando as autoras citadas: com esta pesquisa, objetivo a produção de um conhecimento específico em tradução, identidade e alteridade, que envolva a aplicação ou uso das reflexões surgidas a partir dela na minha prática, uma vez que a pesquisa está relacionada à minha formação acadêmica e atuação profissional.

Assim, os interesses dessa pesquisa estão circunscritos ao ambiente de trabalho do pesquisador, que envolve o ambiente de ensino-aprendizagem de L2 para além do contexto de sala de aula. A pesquisa é altamente favorecida pela proximidade, ou, para ser mais preciso, atuação do pesquisador no campo de trabalho, enxergado também como trabalho de campo. A atuação profissional desenvolvida por mim também se relaciona ao grande favorecimento da fase exploratória da pesquisa.

Nessa etapa é que o pesquisador define qual é o projeto de pesquisa a que vai se dedicar. Na elaboração desse projeto, a hipótese de pesquisa surgiu de minha prática docente em contato com as inquietações e aportes teóricos suscitados pelo ingresso no curso de mestrado.

E foi, ainda, a inserção profissional no contexto de pesquisa que permitiu também que houvesse minha observação participante enquanto pesquisador-professor. Para Minayo, a observação participante permite coleta de dados aprofundada e facilita a compreensão do contexto da pesquisa, do qual o observador faz parte, modificando-o e sendo modificado por ele.

A observação participante é "um processo pelo qual um pesquisador se coloca como observador de uma situação social, com a finalidade de realizar uma investigação científica. [Ele] fica em relação direta com seus interlocutores no espaço social da pesquisa" (MINAYO, 2009, p. 70).

A pesquisa social é um processo que a partir da metodologia científica permite "a obtenção de novos conhecimentos no campo da realidade social" (GIL, 2008, p. 26), o que foi enfatizado na justificativa e na apresentação da introdução desta dissertação como possibilidade de ventilar o campo dos Estudos da Tradução.

Quanto aos objetivos, esta pesquisa combina, de um lado, o caráter exploratório, o qual visa proporcionar maior familiaridade com o problema para explicitá-lo ou 
construir hipóteses e envolve "análises de exemplos que estimulem a compreensão" (SILVA, 2005, p. 21), a, de outro lado, o caráter explicativo, pelo qual se objetiva explicar os fatores que determinam ou contribuem para a ocorrência de determinados fenômenos (GIL, 2002; SILVA, 2005; GERHARDT; SILVEIRA, 2009).

A pesquisa teve, ainda, farto procedimento bibliográfico, uma vez que tem caráter conceitual nos primeiros capítulos, e dialoga com pesquisas de outros autores do campo dos Estudos da Tradução, do discurso, da linguística, entre outros. Tal procedimento justifica-se por essa pesquisa ter-se iniciado com levantamento de fontes bibliográficas (livros, periódicos e artigos científicos, comunicações científicas de congressos), com leitura, análise e documentação (elaboração de resumos e resenhas, discussões teóricas com orientador e examinadora da banca de qualificação, debates em sala de aula com colegas e professores de mestrado).

Essa etapa da pesquisa foi fundamental para delimitar o panorama teórico que fundamentou a elaboração das perguntas que formaram o questionário respondido pelos participantes da pesquisa, o qual está presente no capítulo 03, bem como as respostas e suas análises. Gil (2002) propõe que a pesquisa bibliográfica faz parte de quase todos os estudos, e acredita que a pesquisa bibliográfica tem grande vantagem ao permitir que o investigador acesse "uma gama de fenômenos muito mais ampla do que aquela que poderia pesquisar diretamente" (GIL, 2002, p. 45).

Além da presença do procedimento bibliográfico, realizou-se também uma forma de pesquisa participante, a qual é por vezes tratada na literatura sobre o tema também como pesquisa-ação ou intervenção.

A pesquisa participante é aquela que "se desenvolve a partir da interação entre pesquisadores e membros das situações investigadas" (SILVA, 2005, p. 22). A pesquisaação permite investigações que interferem simultaneamente nas situações e na formação docente, abrindo espaço para posições mais ativas socialmente (ZOZZOLI, 2006).

Rita Zozzoli enfatiza que a pesquisa-ação não é uma pesquisa ativista no sentido de panfletária ou, ainda, associada a movimentos sociais, pois não se limita a uma forma de ação, mas sim pretende "aumentar o conhecimento dos pesquisadores e o conhecimento ou o 'nível de consciência' das pessoas e grupos considerados" (ZOZZOLI, 2006, p. 125).

A autora acima citada defende que a intervenção difere da pesquisa-ação por ter objetivos mais pontuais e contextuais. Aqui, exploram-se as aproximações semânticas 
que existem entre esses termos, e usa-se preferencialmente a noção de pesquisa-ação interventiva em contexto específico. Esse procedimento é adequado por fomentar intervenções no próprio contexto de ensino-aprendizagem, não só em sala de aula mas ainda nas relações de trocas de saberes que se dão a partir da sala de aula.

Assim, permite-se que o professor-pesquisador introduza "ações em sala de aula a partir de sua própria experiência [no grupo de pesquisa, em seu processo de investigação] e retorne com reflexões sobre essas ações" (ZOZZOLI, 2006, p. 123), de forma com que ambos os contextos sejam enriquecidos e alimentados por essas formulações.

\section{PROCEDIMENTOS DE COLETA, SELEÇÃO E ANÁLISE DE DADOS}

Ao decidir fazer as entrevistas, surgiram questionamentos sobre quais perguntas seriam relevantes para o trabalho, como tais perguntas poderiam ser feitas e em qual língua deveriam ser feitas. Dessa forma, tentando ser o mais neutro possível, apesar de ter consciência de que acabei definindo um leque restrito de perguntas para os entrevistados, no terceiro capítulo mostro a entrevista semiestruturada desenvolvida. Para Manzini (1990/1991, p. 154)

A entrevista semiestruturada está focalizada em um assunto sobre o qual confeccionamos um roteiro com perguntas principais, complementadas por outras questões inerentes às circunstâncias momentâneas à entrevista. Para o autor, esse tipo de entrevista pode fazer emergir informações de forma mais livre e as respostas não estão condicionadas a uma padronização de alternativas.

Dessa forma, as perguntas eram feitas em português, mas antes de começar a entrevista eu falava para eles responderem na língua que achassem mais confortável, sem se preocuparem com os erros ou dúvidas de português.

As perguntas da entrevista foram baseadas em um roteiro pré-definido, entretanto tinha a liberdade de fazer todas ou não, assim como de adicionar alguma, dependendo do entrevistado e do decorrer da entrevista. Por ser semiestruturada, também permitiu criar uma maior diferenciação entre os candidatos, uma vez que o rumo depende das respostas dadas por eles, respeitando a alteridade de maneira individualizada. 


\section{CAPÍTULO 1 - CONTEXTUALIZAÇÃO}

Para esta pesquisa, sem pretender esgotar o assunto, destacarei alguns temas contemporâneos sobre a área dos Estudos da Tradução, visando esclarecer melhor meu ponto de vista e lograr alcançar os objetivos da presente dissertação. Esse ordenamento serve para configurar um arcabouço teórico com o qual dialogarei ao longo do trabalho.

Como nos propõe Antoine Berman (2013, p. 27), “A ambição da tradutologia não deveria ser a de estruturar uma teoria geral da tradução, pois tal teoria não pode existir, pois o espaço da tradução é babélico, isto é, recusa qualquer totalização.” E podemos perceber tal espaço babélico no dia-a-dia, no contato com as diferentes línguas-culturas. Uma teoria de tradução com pretensão totalizante ou universal seria, assim, totalitária, e partiria do pressuposto equivocado de que a linguagem é estática.

Cronin, analisando tradução na era da ampla difusão das mídias democratizadas pelas tecnologias virtuais de informação e conexão (de dados e/ou pessoas), em que assistimos a um grande refinamento das máquinas de tradução, enfatiza o caráter social e revolucionário dos projetos de tradução colaborativa que povoam a internet.

A noção de lingua subjacente a esses projetos é de uma extrema dinamicidade e transmutação; isso redefine não só a identidade da tradução como disciplina, campo de atuação, profissão e tecnologia da linguagem (nas palavras do próprio autor), como também redefine a identidade de quem se envolve nesses múltiplos processos de tradução, permeados pela subjetividade de identidades múltiplas, com objetivos variados e que se configuram como uma ferramenta de convívio, portanto, um artefato cultural:

De certo modo, o que ora emerge é uma versão da tecnologia da tradução
definida como ferramenta de convívio e de intervenção política. Implícito
nessa representação da tradução está um movimento de evasão do sujeito
monádico da agência tradutória - São Jerônimo sozinho no deserto - para uma
plurissubjetividade interativa. (CRONIN, 2013, p. 212).

Como vimos na introdução, a língua é dinâmica e está determinada pela cultura, a qual, em situação de complementariedade e retroalimentação, é determinada pela linguagem. A ampliação do conceito de língua pelo de linguagem se relaciona à ruptura com a distinção saussureana entre langue e parole, sendo aquela própria como objeto de estudo e esta, relacionada às interações sociais, tornada desimportante, e que no plano dos estudos do discurso ganha destaque e relevância ao demarcar a indissociabilidade entre língua e uso social, ou seja, discurso. 
É no plano da língua enquanto discurso - noção também discutida na introdução da dissertação - que a concepção de língua de Marcuschi interessa aqui, por ressaltar o caráter dinâmico e cultural da língua:

A língua não é sequer uma estrutura; ela é estruturada simultaneamente em
vários planos, tais como o fonológico, o sintático, o semântico e o cognitivo,
que se organizam no processo de enunciação. A língua é um fenômeno
cultural, histórico, social e cognitivo que varia ao longo do tempo e de acordo
com os falantes: ela se manifesta no seu funcionamento e é sensível ao
contexto. Não é um sistema monolítico e transparente, para "fotografar" a
realidade, mas é heterogênea e sempre funciona situadamente na relação
dialógica, como ensina Bakhtin. (MARCUSCHI, 2011, p. 91)

Para Bakhtin, a dialogia não é mero recurso discursivo e não apenas alude a um diálogo entre um e um outro, mas forma a base sobre a qual os discursos se fundamentam e podem seguir existindo, em um processo marcado, ainda, essencialmente, pela alteridade:

[...] o discurso do outro possui uma expressão dupla: a sua própria, ou seja, a do outro, e a do enunciado que o acolhe. Observam-se esses fatos acima de tudo nos casos em que o discurso do outro (ainda que se reduza a uma única palavra, que terá valor de enunciado completo) é abertamente citado e nitidamente separado (entre aspas) e em que a alternância dos sujeitos falantes e de sua inter-relação dialógica repercute claramente. Mas em todo enunciado, contanto que o examinemos com apuro, levando em conta as condições concretas da comunicação verbal, descobriremos as palavras do outro ocultas ou semiocultas, e com graus diferentes de alteridade. (BAKHTIN, 1997, p. 318).

\subsection{EXPERIÊNCIA PESSOAL}

Com a experiência em sala de aula, passei a encarar a minha língua primeira como uma estrangeira, a qual deveria fazer sentido para aqueles que nunca a haviam estudado. No caso dos alunos imersos no Brasil, país onde estão aprendendo a língua, existe o aprendizado dentro da sala de aula, de forma sistemática, mediada, com o conteúdo dividido (básico, intermediário, avançado) e estrutura curricular baseada em usos determinados da língua, pensados, muitas vezes, sem considerar o contexto, as demandas, as necessidades dos alunos.

Como pontua Zozzoli, o aprendizado nas instituições de ensino tradicionais de hoje em dia pouco mudou com relação aos primórdios da educação institucionalizada (cujo marco remonta ao século IX, na França, com as escolas em catedrais e igrejas 
criadas pelo império). A aprendizagem da leitura e da escrita nas escolas medievais se dava assim:

[...] raros eram os alunos que tinham meios de comprar livros e frequentemente apenas o professor possuía os manuais, que desde essa época já continham princípios e condutas preestabelecidos que seguiam os preceitos de Aristóteles transmitidos pelos primeiros filósofos cristãos. Segundo esses princípios e condutas, a compreensão não era indispensável para o conhecimento e, assim, os alunos eram obrigados a memorizar regras de gramáticas que eram escritas no quadro pelo professor. (ZOZZOLI, 2006, p. 110).

O aprendizado mecânico, sem relação com a vida cotidiana e os objetivos pessoais dos alunos, ainda é dominante nos contextos de ensino e aprendizagem de línguas, sejam elas maternas ou estrangeiras/segunda língua, e isso, segundo Zozzoli, está a serviço da ordem social dominante do capitalismo global, fundamentado na pedagogia das competências, para que as pessoas sejam capazes de integrar-se ao mundo profissional, tornando-se sujeitos sociais do mundo produtivo, tendência que "não considera as múltiplas determinações da atividade humana e centraliza-se no sujeito abstraído das relações sociais" (ZOZZOLI, 2006, p. 107).

No entanto, existe também o aprendizado que se dá fora da sala de aula, um aprendizado totalmente distinto, e o qual se realiza de forma assistemática, sem mediação, sem divisão do conteúdo, e para o qual não é preponderante se a pessoa está num nível básico ou avançado da língua, ou qual é sua origem e quais são seus costumes. Essa aparente falta de parâmetros pode muitas vezes impressionar ou até chocar alguns estrangeiros.

Na Universidade de Brasília temos o Núcleo de Ensino e Pesquisa em Português para Estrangeiros, o NEPPE, que oferece cursos de português para estrangeiros à comunidade em geral, e tem um grande número de alunos membros de corpos diplomáticos de outros países. Além disso, o Núcleo também oferece cursos a estudantes do Programa Estudante Convênio (PEC-G), conforme acordos internacionais firmados com o Ministério da Educação (MEC) e o Ministério das Relações Exteriores; e oferece ainda aulas para as pessoas em situação de refúgio. Importante destacar que os cursos abertos à comunidade são pagos, e já os cursos ofertados aos estudantes do Programa PEC-G e às pessoas em situação de refúgio são gratuitos.

Os principais objetivos do Núcleo são coordenar, supervisionar e promover o ensino por meio de oferta de cursos de português para estrangeiros, incluindo cursos regulares bimestrais ou, nos períodos de janeiro e julho, cursos intensivos. Também visa fortalecer e incentivar a pesquisa científica na produção de conhecimentos na área de 
Português para Estrangeiros. Ou seja, além de oferecer aulas, é também um espaço para pesquisa e desenvolvimento de atividades na área. Além disso, o NEPPE também é posto aplicador do exame de proficiência em língua portuguesa, o Celpe-Bras, que ocorre todos os anos geralmente nos meses de abril e outubro.

Trabalho no Núcleo principalmente com os falantes de espanhol, tanto aqueles que têm o espanhol como língua primeira quanto aqueles que o aprenderam em algum momento de suas vidas.

Minha experiência profissional no NEPPE e com tais alunos tem consolidado minha impressão de que uma língua colabora com a outra. Isto é, os falantes de línguas latinas, como têm uma grande quantidade de léxico compartilhado e uma rápida fase de assimilação da língua, assim como também há semelhanças entre morfologias e sintaxes desse grupo de idiomas, conseguem fazer uma tradução interiorizada para o português com mais facilidade.

Spitzer (2002, apud MASSEY, 2005; tradução minha ${ }^{8}$ ) afirma que:

O conhecimento é dependente da nossa experiência de mundo. [...] Aprendemos porque nossos cérebros são "máquinas de extração de regras". Regras derivadas por indução, métodos e estratégias da transformação de exemplos fornecidos pelo mundo que nos rodeia.

No caso do par espanhol e português, grande parte do léxico é compartilhada, assim como a formação das frases e orações. Por causa disso, o falante de espanhol consegue se comunicar mesmo sem falar a língua do outro (o português). Como propõe Wolfgang Lörscher (1994, p. 89, tradução minha9): “Os alunos muitas vezes têm uma recaída sistemática em sua língua primeira. Ela funciona como um filtro através do qual a língua estrangeira é recebida e produzida".

Podemos considerar que esse filtro é a ortonímia, ou a busca por uma sensação de "soar bem", de familiaridade, a qual está associada à formação de tradutores, conforme teorização de Annie Brisset (2006): "Pensamos na atenção que os tradutores atribuem instintivamente à eufonia do texto-alvo: pressionados a escolher, preferem geralmente a expressão que ‘soa bem' àquela que diz o exato” (BRISSET, 2006, p. 180).

Apesar de questionar essa noção, apresentada pela autora, de algo que diga “exatamente", em determinada língua, aquilo que foi escrito em uma outra, acredito ser

\footnotetext{
8 "Knowledge is dependent on our experience of the world. [...] We learn because our brains are 'rule extraction machines'. Inductively deriving rules, methods and strategies from the processing of examples provided by the world around us."

9 "Learners often systematically relapse into their mother tongue. It functions like a filter through which the foreign language is received and produced."
} 
possível estabelecer um paralelo entre o que a pesquisadora destaca como parte da formação de tradutores, e a prática de aprendizes de uma nova língua-cultura, que estão, contudo, mergulhados nas próprias lógicas internalizadas do(s) idioma(s) em que primeiro se constituíram como sujeitos.

No entanto, outros autores destacam que essa busca de equivalências tradutórias não é apenas unidirecional, mas sim se estabelece uma relação entre as duas línguas, num processo complexo de observação, comparação e escolhas, realizado por cada aprendiz de segunda língua.

Quando se aprende outra língua, mesmo por um método que se assemelhe ao 'método direto', estabelecem-se, via de regra, padrões de equivalência tradutória. Por conta própria, deduz-se a equivalência a partir da observação do funcionamento das duas línguas. (HALLIDAY; McINTOSH; STEVENS, 1964, p. 125, apud RIDD, 2003, p. 96).

Contudo, a relação das semelhanças entre o português e o espanhol não tem somente consequências positivas para o aprendiz. Ao mesmo tempo em que o processo de aprendizagem é rápido no começo, também vemos uma grande fossilização de erros em níveis intermediários e avançados.

Como nos propõem Calvo Capilla e Ridd:

A tradução enquanto processo interpretativo de re-expressão de sentido possibilita a reflexão contrastiva explícita entre as duas línguas. Aprender a traduzir adequadamente permite limitar as interferências evitando associações errôneas e ajuda a substituir equivalências unívocas e improdutivas entre significantes das duas línguas, por outras de caráter funcional e pragmático nas quais o sentido de uma palavra é determinado pelo contexto comunicativo. (2009, p. 165).

Tal uso da tradução ajuda a acabar com a ideia de univocidade, e com o pensamento sobre uma palavra ou uma expressão idiomática sempre ter a mesma tradução na outra língua, independentemente do contexto. Ou seja, a tradução busca a relação funcional e pragmática, e o sentido de uma palavra é determinado pelo contexto comunicativo.

Para Maria Tymoczko, é possível determinar apenas parcialmente a ideologia de uma tradução, e a tradução em si (enquanto novo texto), pelo contexto de partida e "pelo conteúdo do texto de partida - o sujeito e sua representação - mesmo que esse conteúdo possa ser, ele mesmo, abertamente político e incrivelmente complicado enquanto ato discursivo" (2013, p. 116), pois

[...] um tradutor cria, por sua vez, um texto que é uma representação com sua própria força locutória, ilocutória e perlocutória que é determinada por fatores relevantes no contexto de chegada. Desse modo, mesmo num modelo simplificado, a ideologia de uma tradução será uma mistura do conteúdo do 
texto de partida e dos vários atos discursivos instanciados nesse texto que são relevantes no contexto de partida, dispostos em camadas com a representação do conteúdo, com sua relevância para o público receptor, e os vários atos discursivos da própria tradução dirigida ao contexto de chegada; bem como ressonâncias e discrepâncias entre esses dois 'discursos'. (TYMOCZKO, 2013, p. 116-117).

Além disso, cada língua está repleta de protocolos, de contratos sociais, de aspectos pragmáticos que influenciam na semântica e, por isso, é preciso ter um conhecimento que vai além do aspecto linguístico da nova língua estudada. Isso é especialmente relevante quando falamos em segunda língua, em um contexto de uso imediato, com o aprendiz necessitando da língua para o seu cotidiano.

Assim, interessei-me por trabalhar com a temática da tradução como processo de ressignificação do sujeito, para que possa destacar meu olhar enquanto tradutor e professor acerca da relação com as línguas com as quais e pelas quais nos pomos em contato. 


\subsection{TRADUZINDO-NOS}

Nós, seres humanos, possuímos uma condição de indeterminação constitutiva, nós nos inventamos e nos fabricamos linguística e culturalmente de diferentes maneiras. Um reflexo disso é a tradução, a qual nos revela a infinidade de variedades que existem em cada língua-cultura. Por isso, um tema de substancial importância, particularmente nos dias de hoje, com numerosos conflitos envolvendo o eu e o outro, é a questão da alteridade.

Alteridade é esse ponto de intersecção entre eu e outro, dialeticamente posicionado com relação à identidade, a qual pode ser definida “[...] como uma construção social que envolve um processo dinâmico e situado de expor e interpretar quem somos" (BASTOS, 2008, p. 98) e com a qual estabelece uma relação de complementariedade. A relevância de sua discussão passa por diversos campos, como o filosófico, o sociológico, a psicanálise e, mais especificamente para este trabalho, o da linguagem.

Pode-se pensar que, ao falar em tradução, necessariamente falamos em línguas diferentes, ou comunidades linguísticas diferentes. Entretanto, acredito que a língua é permeada pela alteridade e que o processo tradutório ocorre todos os dias, com todos nós, pois sempre estamos buscando uma forma de nos ressignificar na nossa própria língua, com novas palavras, novos hábitos, novas amizades, novas atividades e atitudes.

Para isso, necessitamos compreender e trabalhar nossas identidades de forma relacional à alteridade, compreendendo que estamos em coletividade no mundo e que é precisamente essa relação entre dentro e fora, eu e outro, que constitui quem somos, assim como na noção do signo linguístico de Ferdinand Saussure, em que um signo é si mesmo em relação a suas peculiaridades e a todos os outros signos que não é.

Significar-nos a partir dessa interface entre sujeito e outro, ou seja, entre identidade e alteridade, permite que passemos a ver coisas que já não víamos, sentir sensações diferentes e até portar-nos de maneira distinta. Pois, assim como a linguagem, o processo de subjetivação, isto é, de tornarmo-nos sujeitos, de nos constituirmos em uma identidade, é dinâmico, instável, e passível de mudanças relacionadas ao contato com outros sujeitos, com o contexto, com o próprio passar do tempo.

Metaforicamente, o processo identitário é um processo de tradução constante, em que estão em contato percepções, expectativas, condutas internas e externas. Uma forma 
de tradução para o mundo e também de autotradução, capaz de surtir a imagem da tradução como um desejo ou condição inata à condição humana.

No plano efetivo da tradução constante de identidades em contato, propiciado pelo ensino e aprendizagem de uma nova língua-cultura, esse desejo inato de traduzir leva-nos também a descobertas de potencialidades da nossa língua primeira e até de recursos não aproveitados, aumentando nossos horizontes linguísticos. E, a partir desse desejo inicial, partimos para a descoberta de uma nova língua, baseados no conhecimento que temos da nossa própria.

Como destaca Ricoeur (2011, p. 11), "é esse desejo de acolher a língua estrangeira, no processo de transformação e de reconfiguração da própria língua, que conduz ao dilema prático, cuja solução passa pela construção do comparável”. Para aprender uma nova língua, temos que aprender a ser nessa nova língua, trazendo como bagagem o ser já aprendido que construímos em nossa língua primeira.

A tradução é necessária por ser uma tentativa de propiciar a comunicação entre os povos, mas ao mesmo tempo é impossível por deparar-se com as barreiras construídas pelo outro, pelo diferente. Esse movimento constitui o double bind sobre o qual fala Derrida (2002), que é o paradoxo da atividade tradutória.

Tal atividade enfrenta as diferenças estruturais e culturais. Tradicionalmente, a tradução era vista como uma cópia que deveria espelhar uma identidade, buscar uma equivalência ilusória da forma e do conteúdo, ou seja, uma tarefa que beira o impossível: despir-se de suas perspectivas e ideologias.

E dessa maneira foi que se consolidou um pensar dominante sobre o processo tradutório, visto apenas como uma substituição ou transferência de significados estáveis de um texto para outro, em que toda e qualquer alteração com relação a um suposto "original ideal”, o qual deveria ter uma única possibilidade interpretativa possível e correta (aquela a ser traduzida equivalentemente), era rotulada de "erro" ou "desvio".

Essa ideologia da tradução como transmissão de conteúdos estáveis pede que não haja a presença de um sujeito, humano, contextual e histórico, o qual realizaria, no trabalho de tradução, interferências textuais. Assim, está constituída uma política e uma ética tradutórias baseadas na transparência e no apagamento de quem traduz (GODARD, 1989).

Kramsch (1998, p. 3) nos explica que tal ponto de vista se sustenta nas concepções de linguagem e signo adotadas pela semiologia clássica, que remonta a Platão. Nesse 
âmbito, a língua seria um conjunto de signos e, dessa forma, seria secundária e derivada da realidade superior ao seu redor; a função dos signos seria realizar a mimese, ou seja, a representação simples do mundo exterior.

As línguas, assim, seriam apenas invólucros para os significados fixos da realidade, o que permitiria ao tradutor encontrar, em sua língua, elementos que correspondessem exatamente a termos da língua estrangeira. No entanto, tais concepções têm sido revistas e, com base no princípio da diferença, defende-se a multiplicidade e heterogeneidade própria de línguas, povos e culturas. E com base nos estudos culturais, enxerga-se nos signos uma significação não mais inerente e arraigada, mas construída no seio cultural.

A traduzibilidade produz uma via de mão dupla entre as culturas, pois a alteridade só é compreensível se levarmos em consideração a nossa própria cultura como base. Entretanto, esta se modifica, constantemente, no contato com o outro. É a negociação permanente entre estranhamento e familiaridade, entre desconhecido e conhecido que representa, em última instância, o modo pelo qual os sistemas culturais se organizam e se movimentam.

Quando nos deparamos com o intraduzível, tanto na nossa língua, como na do outro, ele aparece não como aquilo que determina o fracasso de uma tradução, mas sim como aquilo que permite sua prática efetiva, visto que esse processo implica a aceitação de uma perda e de um ganho. Isso acontece em decorrência da diversidade das línguas, ou seja, as diferenças no recorte do real operado por cada sistema sintático-lexical e na maneira de recompô-lo no nível do discurso.

Com relação a esse tema, Ricoeur acrescenta que "produzir semelhança implica identificar o mesmo no outro e o outro no mesmo. O semelhante surge então da possibilidade de perceber a identidade na diferença e a diferença na identidade" (2011, p. 15). O autor complementa mais adiante que "a hospitalidade linguística é onde o prazer de habitar a língua do outro é compensado pelo prazer de receber em casa, na acolhida de sua própria morada, a palavra do estrangeiro" (p. 30, ibid).

Em outras palavras, para o autor, um projeto político de tradução faz-se possível somente num encontro de alteridades, sobre o qual também fala Barbara Godard ao comentar a tradução como um "[...] eco de si e da outra, um movimento rumo à alteridade" (GODARD, 1989, p. 44). Segundo a autora, é imprescindível questionar a política da transparência do discurso e da tradução, desconstruí-la, e sem seu lugar fazer surgir uma 
poética da alteridade, com vistas ao caráter emancipatório da linguagem que ela frisa, como comentado na introdução desta dissertação.

Nesse sentido, o projeto político de tradução ressoa como uma alternativa ao projeto político de ensino e aprendizagem de línguas comentado e questionado anteriormente por Zozzoli, com vistas à destituição do modo reprodutivista, conteudista e curricular da educação a serviço de um projeto de mundo fundamentado na dominação pelo capitalismo global; e ainda a pedagogia libertadora de Paulo Freire, para quem a leitura do mundo antecede a leitura da palavra e deve ser sempre parte de um projeto de libertação humana e desconstrução das categorias de oprimido e opressor.

Para essas autoras e esse autor, qualquer projeto de emancipação humana passa pela linguagem. Godard explicita a relação entre emancipação e tradução, uma vez que era uma teórica dos Estudos da Tradução. Sugiro, assim, que aproximemos essa proposta feita por ela, Freire e Zozzoli à compreensão do processo complexo de constantes traduções realizadas por aprendizes de um novo idioma que, mais que dominar uma nova língua-cultura, estão aprendendo a ser novos sujeitos nela. O que, se não pode ser considerado efetivamente como um processo de emancipação, pode, sim, ser considerado como uma possibilidade de expansão de suas fronteiras identitárias, assim como das fronteiras linguísticas que cada aluno traz como parte fundamental de sua herança cultural.

Quando nos traduzimos para uma nova língua, estamos nos modificando, assim como não somente os campos semânticos não são iguais: também as sintaxes, as formas de construção das frases nos levam a outras heranças culturais; assim como também são outras as conotações e denotações mais precisas do vocabulário de origem, que flutuam de certo modo entre os signos, as frases, as sequências curtas e longas.

Duas possibilidades se apresentam quando penso no ato de traduzir: primeiro, pode-se entender o termo "tradução" no sentido estrito, ou seja, de transferência de uma mensagem verbal de uma língua para outra. Em segundo lugar, podemos interpretá-lo em um sentido mais amplo, como interpretação de todo conjunto significante existente no interior de uma mesma comunidade linguística.

É bem verdade que nossas palavras têm, cada uma, mais de um sentido, como se vê nos dicionários, e a esse fenômeno podemos chamar de polissemia:

Há palavras que possuem mais que uma possível significação em qualquer contexto ou situação, em comparação com outras [...] Esse fenômeno é conhecido com o nome de polissemia, e está presente em todas as línguas humanas, sendo talvez um de seus traços mais característicos. Na polissemia 
jogam dois fatores distintos: um, de caráter psicológico, baseado na economia do código, que faz com que um falante não tenha que armazenar mais que uma forma fonética para vários significados próximos; outro, um fator de caráter evolutivo, que faz com que, no progresso de uma sociedade que fala uma língua determinada, algumas palavras possam especializar-se com outros significados em línguas técnicas. (BLECUA, 1979, p. 43-54).

O sentido é, a cada vez, delimitado pelo uso, o qual consiste essencialmente em tirar a parte do sentido da palavra que convém ao resto da frase e em como este concorre para a unidade do sentido exprimido e oferecido. Assim, é a cada vez o contexto que decide sobre o sentido assumido pela palavra numa tal circunstância de discurso, e não apenas um retilíneo caráter evolutivo; conta aqui a importância do uso social da língua.

Blecua alerta, entretanto, para que tampouco a medida do contexto seja desmesurada, ao explicitar que contexto e situação, como elementos primordiais na linguagem, algumas vezes tenham tido sua importância "levada a extremos exagerados, como quando se afirma que basta o contexto ou a situação para atribuir um determinado significado a uma combinação de elementos fonéticos" (BLECUA, 1979, p. 51). Para o autor,

\begin{abstract}
O contexto é, pois, fundamental em qualquer processo de comunicação, não somente porque em todas as línguas naturais existem palavras que podem ter vários significados, mas também porque em todas as línguas existem palavras cujo significado vem dado pelo contexto, e também pelo conjunto de circunstâncias externas que envolve a comunicação (conjunto que normalmente costuma ser distinguido com o nome de situação). (BLECUA, 1979, p. 50, grifo do autor).
\end{abstract}

Além disso, há também os contextos escondidos e as "conotações", as quais nem sempre são intelectuais, mas sim afetivas, e nem sempre são públicas, mas próprias a um meio, ou uma classe, ou um grupo. Tudo isso ocorre em razão de nós não termos descrições completas do mundo, somente pontos de vista, visões parciais - ainda que consolidados pela permanência ao longo do tempo e/ou a adesão de muitos falantes àquela percepção, conceito, ideia, com a forma de tradições epistêmicas as quais parecem, por vezes, desafiar a dinamicidade da linguagem.

É por isso que não terminamos nunca de nos explicar com as palavras e com as frases, de nos explicar a outras pessoas que não veem as coisas sob o mesmo ponto de vista que o nosso: porque a linguagem é um arranjo mais ou menos estável, reatualizado constantemente pelo uso. Os textos que emitimos, oralmente ou por escrito, todos fazem parte desse jogo que a linguagem estabelece.

Dell'Isola define linguagem como um atributo humano que não serve apenas à comunicação ou à interação social. Para a autora, a função básica da linguagem é a 
reflexão e a construção do pensamento, as quais se realizam apenas parcialmente nas interações sociais: "Mais do que ser mensagem, mais do que ser veículo de ideias e sentimentos, a linguagem é criação e representa o modo como organizamos as nossas experiências e é a nossa forma de expressão. " (DELL'ISOLA, 2013, p. 40).

Como visto anteriormente, de forma incisiva, de acordo com a perspectiva bakhtiniana, a linguagem é uma forma de interação social, através da qual as pessoas estabelecem relações sociointerativas: "Todas as esferas da atividade humana, por mais variadas que sejam, estão sempre relacionadas com a utilização da língua" (BAKTHIN, 1997, p. 280). Nessa abordagem, a língua "só se atualiza a serviço da comunicação intersubjetiva, em situações de atuação social e através de práticas discursivas, materializadas em textos orais e escritos"(ANTUNES, 2003, p. 42).

Para a presente pesquisa utilizo duas definições de texto. A primeira é a de Zozzoli, que ressalta os alcances da Linguística Textual em conectar à análise linguística uma análise discursiva, e não fraseológica:

\footnotetext{
A Lingüística Textual contribui para ultrapassar a análise no nível da frase para o nível do texto, considerando-o não como uma soma de frases, mas como "toda unidade de produção de linguagem situada, acabada e autossuficiente (do ponto de vista da ação e da comunicação)" (BRONCKART, 1999, p. 75).

Visto desse modo, o texto tem as seguintes propriedades: coerência, coesão, informatividade, situacionalidade, intertextualidade, intencionalidade e aceitabilidade. (ZOZZOLI, 2006, p. 111).
}

A segunda foi proposta por Costa Val, a qual também enfatiza as propriedades de textualidade destacadas por Zozzoli - as quais reforçam o aspecto sociocomunicativo e interativo do discurso. Para Costa Val (2006, p. 3), “[...] pode-se definir texto ou discurso como ocorrência linguística falada ou escrita, de qualquer extensão, dotada de unidade sociocomunicativa, semântica e formal. É uma unidade de linguagem em uso."

Assim, também segundo a autora, um texto tem caráter interativo intrínseco. E a produção remete aos sujeitos que simultaneamente o constituem e se constituem a partir dele. Assim que é a relação de alteridades que provoca mudanças: temos que fazer algo para que o outro caiba na nossa língua ou para que caibamos na língua do outro. E, a partir do momento em que traduzimos, já não somos os mesmos, ou seja, o texto modifica também quem o traduz.

Tanto os textos escritos como os orais surgem então como mais que encadeamentos de frases: eles atuam tecendo o discurso em sequências longas ou curtas. Pensamos aqui na retórica, com suas figuras de estilo, com metáforas e jogos de linguagem, os quais provocam muitas dúvidas na hora de traduzir. Essas dúvidas da 
tradução de uma língua para outra encontram sua origem na reflexão da língua sobre ela mesma, o que leva Steiner (1976) a dizer que "compreender é traduzir".

Steiner explora os usos verbais nos quais se busca outra coisa que não o verdadeiro, o real, ou seja, não somente a mentira - ainda que falar seja poder mentir, dissimular, falsificar, mas também tudo que podemos classificar como outra coisa que não o real: o possível, ou o hipotético, ou o utópico. Além de poder dizer a mesma coisa de outro modo, a linguagem diz outra coisa além do que é.

E como destaca Ricoeur (2011, p. 12):

A diversidade das línguas afeta todos os níveis operatórios da linguagem: o recorte fonético e articulatório na base dos sistemas fonéticos, o recorte lexical que opõe as línguas, não de palavra a palavra, mas de sistema lexical a sistema lexical; as significações verbais no interior de um léxico consistindo numa rede de diferenças e de sinônimos; o recorte sintático, afetando, por exemplo, os sistemas verbais e a posição de um evento no tempo ou ainda os modos de encadeamento e de consecução.

Por isso, quando pensamos em uma nova língua-cultura não podemos nos restringir apenas à língua como um sistema fixo, ela está em constante formação, em construção, é algo dinâmico, pois recebe influência de outras culturas, além de ser continuamente modificada pelos sujeitos que nela se fazem e a fazem.

Além disso, quando mudamos o significante, mudamos também o significado, pois o conceito muda entre as culturas - o que não muda é o referente. Isto significa que não falamos sobre a realidade, mas sim sobre a percepção que temos da realidade, pois a linguagem cria mundos, além de meramente expressá-los. Dessa forma, pensar em outra língua é uma atividade bastante complexa, pois necessitamos criar novos significados, não somente significantes.

Derrida propõe que "cada significante só adquire significado ao remeter a outro significante, passado ou futuro" (apud RODRIGUES, 1999, p. 199). Assim, cada elemento se encontra capturado em uma rede tecida por outras palavras e por outras configurações textuais e sempre se relaciona com outros. Ou seja, independentemente da sua língua primeira, o aprendiz tem de se ressignificar dentro dessa nova rede.

Outro ponto interessante a ser destacado é que o objetivo da tradução não seria o texto, mas o processo, ou seja, envolve o sujeito que se manifesta, a linguagem, além de temas dos mais diversos assuntos. Dessa forma, a tradução passa a ser vista como uma atividade e, como consequência, o pensamento não é mais anterior, mas sim posterior a essa atividade. Derrida (1972) inclui o sujeito e a sociedade, permitindo distinguir os 
problemas da língua. Ele vai, assim, tratar da tradução do discurso, ou seja, do texto manifestado. E propõe que só há traduzibilidade quando falamos em sujeito e que, enquanto falamos da língua, falamos do intraduzível.

Isso leva a uma percepção de que produzir discursos, traduzidos ou não, implica refazer-se constantemente na língua: o sujeito há que ser sempre outro - o discurso é o lugar dessa alteridade íntima e constante. E a tradução torna-se assim espaço daquela poética da alteridade definida por Godard, e outros autores: “A tradução é uma aventura que nos leva para fora de nós mesmos. Nesse ato de revelação da alteridade, estão sempre muito presentes o prazer e o temor de abrir uma porta que nos conduzirá ao outro." (OLIVEIRA, 2009, p. 82).

\subsubsection{DISCURSO}

É muito importante diferenciar o que se faz com a língua, o discurso, do quanto se sabe sobre a língua, a estrutura, pois não necessariamente existe uma relação simétrica ou uma relação de causa e efeito entre as duas atividades. Por exemplo, se eu não sei nada de física e vou para uma aula de física quântica, apesar de entender português, não entenderei a aula, pois eu só saberei a língua, mas não saberei o discurso da Física. Isto é, a estrutura da língua só adquire potencial nos diferentes discursos, e o que era proposto por Saussure em termos de oposição entre língua/fala passa a dar lugar a outra relação: língua/discurso, constituída por meio do uso da língua.

A Teoria dos Atos de Fala, desenvolvida por Austin na década de 50, procurava uma sistematização da linguagem. Através dela, o autor destaca que todo discurso é contextualizado, historicamente e geograficamente, e que o texto está cheio de intertextualidade. Todo discurso também é regido por normas, por protocolos sociais, por tipos e gêneros de textos. Assim como todo discurso é um interdiscurso, ou seja, é derivado de outro discurso. Por mais que não percebamos, estamos imersos em redes discursivas e variamos nossos discursos dependendo da situação, mas usando uma fonte enunciativa em comum, simultaneamente contemporânea e ancestral:

O enunciado é um elo na cadeia da comunicação verbal. Tem fronteiras nítidas, determinadas pela alternância dos sujeitos falantes (dos locutores), mas dentro dessas fronteiras, o enunciado [...] reflete o processo verbal, os enunciados dos 
outros e, sobretudo, os elos anteriores (às vezes os próximos, mas também os distantes, nas áreas da comunicação cultural). O objeto do discurso de um locutor, seja ele qual for, não é objeto do discurso pela primeira vez neste enunciado, e este locutor não é o primeiro a falar dele. $\mathrm{O}$ objeto, por assim dizer, já foi falado, controvertido, esclarecido e julgado de diversas maneiras, é o lugar onde se cruzam, se encontram e se separam diferentes pontos de vista, visões do mundo, tendências. (BAKHTIN, 1997, p. 319).

Também destaco o conceito de enunciação desenvolvido por Émile Benveniste, quem diz que a língua é o lugar da intersubjetividade, o lugar onde os indivíduos se confrontam, onde encontram outrem (DUCROT apud VOGT, 2009, p.13). Tal afirmação vem corroborar a ideia de alteridade e a necessidade que temos de destacá-la dentro dos Estudos da Tradução, pois a familiaridade com nossa língua primeira pode nos levar a acreditar em uma única maneira de ver o mundo, como se todos fossem semelhantes a nós mesmos.

Já a tradução tem o papel de descentrar, de expandir as fronteiras, de conhecer o que é outro. A operação da tradução mostra as diferenças e as igualdades entre as línguas e deixa aparecer outra língua na nossa, num processo de complementação entre as línguas em contato, o qual pode ser marcado tanto por conflitos quanto por acomodações.

Podemos ver a enunciação como o ato de apreender uma língua e pô-la em funcionamento, por exemplo: um "eu” produz linguagem para um "tu". Entretanto, além de eu e tu, que pertencem à esfera de pessoa, a enunciação constitui outras esferas, igualmente necessárias: o tempo e o espaço da enunciação, os quais assumem seus sentidos a partir da primeira.

Orlandi (1987) coloca que:

[...] o texto não é uma unidade completa, pois sua natureza é intervalar. Sua unidade não se faz nem pela soma de interlocutores nem pela soma de frases. O sentido do texto não está em nenhum dos interlocutores especificamente, está no espaço discursivo dos interlocutores; também não está em um ou outro segmento isolado em que se pode dividir o texto, mas sim na unidade a partir da qual eles se organizam. (apud MEDEIROS, 2011, p. 55).

Daí haver uma característica indefinível no texto que só pode ser aprendida se levarmos em conta sua totalidade, visto que interpretamos apenas uma parte deste; assim, corremos o risco de nos equivocar em relação ao todo.

O referente de um discurso não é uma realidade absoluta, mas sim o que o discurso define como realidade, isto é, a linguagem não representa a realidade, o mundo, mas, por meio dela, o locutor apresenta a sua realidade, o seu mundo. Por isso temos diversos 
discursos sobre um mesmo referente. O sentido como um todo só será preenchido no uso social, de forma dialógica, conforme fica explícito na seguinte análise proposta por Bakhtin:

A expressividade de um enunciado nunca pode ser compreendida e explicada até o fim se se levar em conta somente o teor do objeto do sentido. A expressividade de um enunciado é sempre, em menor ou maior grau, uma resposta, em outras palavras: manifesta não só sua própria relação com o objeto do enunciado, mas também a relação do locutor com os enunciados do outro. [...] Pois nosso próprio pensamento - nos âmbitos da filosofia, das ciências, das artes - nasce e forma-se em interação e em luta com o pensamento alheio, o que não pode deixar de refletir nas formas de expressão verbal do nosso pensamento. (BAKHTIN, 1997, p. 317).

Gnerre (1991, p. 3) propõe que "a linguagem não é usada somente para veicular informações", e com isso compreende-se que há outras funções além da referencial denotativa da linguagem. Entre as tantas funções possíveis, a língua também diz respeito a uma posição que o falante ocupa de fato ou acha que ocupa na sociedade em que vive, criando laços com a comunidade.

\subsection{SEMELHANTES ESTRANHOS}

Nos dias de hoje é clara e crescente a demanda pelo aprendizado do português, tanto no Brasil como nos países da América do Sul. Como o Mercosul tem o português e o espanhol como línguas oficiais, a famosa interlíngua conhecida popularmente como "portunhol" não é suficiente nem para a comunicação oral nem para a escrita dos documentos oficiais. Tal situação nos coloca um público muito específico de aprendizes do português brasileiro: o falante de espanhol latino-americano.

O português e o espanhol são vistos como línguas irmãs, por serem da mesma família linguística, as neolatinas. Ambas têm um tronco comum, o latim, e uma história evolutiva paralela, e essa proximidade é um primeiro fator que nos permite concluir que algo aproxima linguisticamente falantes das duas línguas. Essa condição destaca uma proximidade tipológica entre as duas línguas, na qual a ordem da oração é bastante parecida entre ambas. Na língua escrita, principalmente, as semelhanças aparecem ainda mais visíveis e a outra língua parece mais compreensível. Ulsh (1971) estabelece, por exemplo, que mais de $85 \%$ do vocabulário português tem cognatos em espanhol. 
Todavia, não podemos confundir a quantidade de cognatos com o uso da língua. O fato de haver essa expressiva porcentagem de cognatos não significa que usamos essas palavras nos mesmos contextos, registros e situações de uso. Além disso, existem diversos aspectos extralinguísticos que influenciam na forma como nos expressamos em diferentes contextos dentro da língua, principalmente quando se trata de pessoas que moram no país onde a L2 é falada.

Oller e Ziahosseiny (1970) propõem que a interferência pode, na realidade, ser maior quando os itens a serem aprendidos são mais semelhantes aos itens já aprendidos do que quando totalmente novos e não relacionados com conhecimentos anteriores.

Com minha experiência no ensino de português para estrangeiros, percebo que, do ponto de vista estrutural da língua, os falantes de espanhol têm certas vantagens em relação a outros estrangeiros, pois um aluno hispanofalante entende uma grande parte do que é dito em português sem haver estudado nada antes. Entretanto, não se pode afirmar que, do ponto de vista discursivo, existe a mesma vantagem, pois os estrangeiros não conhecem nossa cultura, nem nossas tradições e formas de conduta em diferentes situações.

Até mesmo dentro da mesma língua, dependendo do ambiente e do objetivo, mudamos nossas formas de falar e de nos portar. Por isso, acredito que quando falamos em proximidade linguística acabamos restringindo-a a uma visão de língua meramente estrutural, uma vez que não percebo que os hispanofalantes também tenham vantagens sobre os alunos com línguas consideradas distantes sobre a questão da formação do discurso, da prática social e da ressignificação do sujeito na língua-cultura brasileira.

Destaco, além disso, que as dificuldades são uma decorrência variável a qual combina os aspectos internos e externos do processo de ensino-aprendizagem, como perfil motivacional, a identificação ou não com a cultura associada à língua alvo, bloqueios e/ou experiências anteriores frustrantes, níveis de ansiedade, assim como a abordagem de ensino do professor, material didático, tipos de atividades desenvolvidas no curso para experimentar a nova língua etc.

Outra questão é a produção de aspectos fonológicos que impactam o aprendizado, como destaca Almeida Filho (1995): a nasalização, a distinção entre fonemas vocálicos abertos e fechados, o desvozeamento (ou ensurdecimento) de consoantes; a presença de sonoras fricativas intervocálicas, do alçamento de fonemas vocálicos na língua (como em 
'tarde'/tardi) e de aspectos fonológicos suprassegmentais (português como língua de ritmo acentual, e espanhol como língua de ritmo silábico).

Almeida Filho observa que na interlíngua (os sistemas transicionais que vão emergindo na competência dos aprendentes), o aluno chega a uma estabilização em "certo patamar intermediário ou mesmo estaciona no que denominamos nível de interlíngua fossilizado" (1995, p. 18). Essa fossilização quando tomamos o par linguístico em questão pode acabar criando, no aluno, o que o autor considera uma zona de facilidade enganosa com relação a sua vivencia cognitiva e sócio-afetiva.

Ferreira (2001, p. 141) amplia a definição de interlíngua:

Selinker (1972) define interlíngua como sistemas intermediários entre a língua materna e a língua-alvo, e que possuem características próprias, sendo influenciados não só por transferências da língua materna, como por outros fatores, até mesmo elementos da própria interlíngua.

Krashen (1982) propõe que não é o fato de uma alta frequência de exposição a certas estruturas que fará com que elas sejam adquiridas mais rapidamente. Ao contrário, segundo a linguista, o aluno vai adquirir somente aquilo que estiver no nível de seu desenvolvimento maturacional, que Krashen denomina i+1. Por isso, o fato de um falante de espanhol estar em imersão no Brasil não é condição essencial para a aquisição, apesar da sua constante exposição à língua-alvo.

Ao destacar a questão da proximidade entre as línguas, pretendo mostrar que esses "semelhantes", o português e o espanhol, por vezes, são "estranhos", pois, apesar de grande parte do léxico ter cognatos na outra língua, o uso é diferente e a relação com a língua é diferente, já que o estrangeiro, mesmo em um país que fala a mesma língua do seu país natal, porta-se de maneira diferente, pois não conhece os costumes e as peculiaridades daquele lugar, quanto mais em um país com outra língua, que apesar do léxico ter semelhanças, a maneira de ser na outra língua-cultura é muito distinta e, nesse aspecto cultural e pragmático, ser falante de espanhol ou de outra língua, não ajuda na compreensão, pois são especificidades mais profundas de cada língua-cultura.

\subsection{LÍNGUA-CULTURA}

La sociedad, al instituirse, también se nombra y así se distingue de otras sociedades. Una sociedad se llama Atenas, otra se llama Tenochtitlan y otra Babilonia. Cada uno de los miembros de la 
sociedad también tiene un nombre. Así, cada sociedad y sus miembros ingresan en el universo de los nombres, en el mundo de los signos: la sociedad es un lenguaje. La cultura de una sociedad es casi ininteligible si se desconocen los significados de su lenguaje. (PAZ, 1990, p. 10).

Octavio Paz argumenta que em todas as sociedades existe tanto um saber especializado, com suas técnicas e linguagem próprias, quanto saberes, crenças e linguagens coletivas, isto é, tanto o teórico como o popular fazem parte da mesma cultura. $\mathrm{O}$ autor critica a dualidade que correntemente se tenta demonstrar haver entre as culturas das sociedades modernas, nas quais convivem inúmeras expressões.

Por exemplo, fala-se em cultura popular e cultura erudita, alta e baixa cultura, literatura e para-literatura, entre outros. Os vínculos entre a denominada alta cultura e a cultura popular dão-se de modo permanente e essas duas formas de expressão estão profundamente ligadas ao cotidiano de qualquer sociedade.

Quando falamos em ensinar cultura, primeiramente caímos no pensamento de cultura baseada em estereótipos, como se pudéssemos descrever uma cultura geral brasileira, ou de qualquer outro país. Uma vantagem de ter alunos que estão imersos no nosso país é que eles podem ver que existem diferenças culturais nacionais, e que portanto as pessoas são diferentes umas das outras. Eles passam por situações positivas e negativas no Brasil, as quais ajudam a quebrar o estereótipo do "brasileiro". Dessa forma, o estudante, aos poucos, deixa de falar em uma "sociedade brasileira" única.

Revuz destaca que

\begin{abstract}
A língua estrangeira não recorta o real como o faz a língua materna. [...] que o sol seja feminino em alemão, que os ingleses digam "eu sou frio" e os russos "a mim, 25 anos", é desconcertante, e muitos são os que ficarão fiéis a suas faltas de gênero ou sintaxe antes de adotar outra maneira de ver as coisas. (REVUZ, 1998, p. 223).
\end{abstract}

A arbitrariedade do signo linguístico provoca uma estranheza, que pode ser vista como perda de uma identidade vinculada à língua primeira, ou pode ser considerada um acréscimo, uma construção de novas identidades, que vêm somar, vem conviver com as primeiras ou com as outras já existentes. O aprendiz alcança não somente um conhecimento da cultura estrangeira, mas também uma autorreflexão e um olhar crítico sobre sua própria cultura, o que pode incidir na diminuição do uso de rótulos generalizadores. 
Algumas ideias são muito difundidas sobre o Brasil, como o futebol, o samba, o carnaval, a feijoada, a caipirinha serem traços nacionais. Entretanto, cabe aos professores relativizarem essas ideias, a fim de mostrar que nem todos os brasileiros gostam de futebol ou de samba, ou comem feijoada e tomam caipirinha todas as semanas. Mostrar que a cultura não é somente baseada em estereótipos materiais.

Entretanto, o léxico também reflete a cultura na língua, pois revela a forma como certa comunidade linguística enxerga e interpreta sua realidade, assim como a modifica de acordo com os acontecimentos históricos.

Devemos a Taylor a primeira definição etnológica de cultura:

Cultura e civilização, tomadas em seu sentido etnológico mais vasto, são um conjunto complexo que inclui o conhecimento, as crenças, a arte, a moral, as leis, os costumes ou qualquer outra capacidade ou hábitos adquiridos pelo homem como membro de uma sociedade. (TAYLOR, 1871, apud LARAIA, 2005, p. 25).

Já na definição de Kramsch (1998, p. 64) a cultura é formada por:

Estruturas de significados estabelecidos pelo social, além de entendê-la como compreensão dos sinais ou signos por meio dos quais os falantes de uma determinada língua dão sentido ao mundo ao seu redor. A cultura não trata de fatos e comportamentos isolados estabelecidos por algum princípio absoluto, não é poder, é um conjunto de concepções e expectativas inserido em um determinado contexto que se torna normal em um grupo social.

Galisson (1991, p. 395) afirma que "é enquanto prática social e produto sóciohistórico que a língua é penetrada de cultura. O jogo de simbiose do qual participam língua e cultura faz com que elas sejam o reflexo recíproco e obrigatório uma da outra". Ou seja, a língua é uma parte da cultura com suas crenças, costumes e instituições, e ao mesmo tempo é produto da cultura por refletir as características gerais de uma sociedade.

As experiências das pessoas que compõem uma comunidade são criadas através da língua que compartilham. Os significados verbais e não verbais, desde a escrita à fala, passando por tom e altura de voz, pronúncia, estilo conversacional, gestos e expressões faciais, e mesmo os silêncios, tudo isso criado pelas pessoas em suas comunidades, só pode ser compreendido devido ao uso comum da língua.

Dessa maneira, é essencial que as pessoas envolvidas no processo de comunicação dominem não só a língua, como também os repertórios culturais que fazem parte da sociedade.

Brown (1994) aponta que um dos principais problemas em entender o discurso em uma língua estrangeira vem da falta de conhecimento suficiente dos aspectos culturais, aos quais esta língua está ligada. O conhecimento intercultural envolve a descoberta e a 
compreensão dos pensamentos e dos comportamentos condicionados que temos em nossa própria cultura, assim como da estrutura de outras. O problema, para Kramsch (1998), é que os professores ensinam língua e cultura, ou cultura na língua, mas não a língua como cultura.

O aluno deve aprender uma nova língua, mas sem desvalorizar a sua própria língua, pois isso pode gerar diferentes sentimentos no aprendiz, como: medo, irritação, frustração, dentre outros. Para isso é necessário compromisso ético do professor, que saiba também evitar estereótipos sobre a língua-cultura do aprendiz, e que ainda se responsabilize por garantir que as comparações entre traços constitutivos das línguas em contato não sejam feitas de forma hierarquizante, desvalorizante.

Ito (1991) apresenta algumas diretrizes para favorecer o surgimento dessas práticas multiculturais, às quais acredito que devemos atentar:

a) Todas as línguas possuem expressões idiomáticas cujas conotações estão além do significado de cada uma de suas partes constitutivas, portanto, numa LE não se pode traduzir palavra por palavra;

b) Cada língua é acompanhada de uma mímica distinta, de acordo com o que se quer expressar, e a entonação que se dá a uma frase está carregada de significado;

c) Cada língua tem uma gramática diferente;

d) Em toda língua existem termos-tabus;

e) Existem determinadas regras para se dirigir às pessoas em determinadas situações.

A partir dessas observações, pode-se tornar a sala de aula de segunda língua um ambiente multicultural rico e propício ao contato de línguas que enriquece não só o repertório cultural e linguístico do aluno, mas também o do professor, bem como as culturas-línguas relacionadas em cada contexto de ensino e aprendizagem.

Se podemos ousar ir um passo além, proponho uma perspectiva transcultural a qual, segundo Bernd (2005), pode suscitar a superação dos "binarismos conflituais centro/periferia, colonizador/colonizado, [criando] condições favoráveis à emergência de uma dialética fecunda, dando origem a novos lugares de enunciação [...]” (BERND, 2005, p. 149).

A pesquisadora ressalta que a vantagem do conceito de transculturação está no fato de sua própria etimologia estar associada às transições, por originar-se de transire, o 
que ecoa à noção de trânsito, transitar em português brasileiro: ou seja, passar para o outro lado, implicando em um processo de transformação ao invés de um processo que envolva identificação ou assimilação:

[...] os estudos das transferências culturais (transculturalisms) são essenciais para as sociedades industriais avançadas, pois eles nos permitem romper com o pensamento do imobilismo comunitário, do sedentarismo e da pertença incontestável a um lugar [...] Graças às transferências culturais, os escritores das Américas situados em uma encruzilhada de línguas, de memórias e de culturas vivem a babelização atual sobre a forma de impasses, de dificuldades, mas também de tensões produtivas. Esses impasses dão origem a mixagens originais que levam o sujeito a se repensar no espaço cultural americano. (BERND, 2005, p. 152).

No caso dos sujeitos que colaboraram com a presente pesquisa, os quais estão aqui definidos como aprendizes, mas são também escritores e leitores do mundo e não só da palavra, e estão também em trânsito por esse território vasto da América Latina. Creio também ser possível, a partir dos processos tradutórios que o contexto de ensino e aprendizagem do português brasileiro como segunda língua favorece, que se localizem criticamente, realizando esse exercício no limiar entre identidade e alteridade para repensar-se no espaço cultural brasileiro, em interface com as heranças nacionais e/ou étnicas trazidas de seus contextos. 


\section{CAPÍTULO 2 - ALTERIDADE E IDENTIDADE}

\subsection{ALTERIDADE, O PARADOXO NECESSÁRIO:}

A alteridade pode ser vista como a qualidade ou o estado do que é outro ou do que é diferente. Um dos princípios fundamentais da alteridade é que o homem na sua vertente social tem uma relação de interação e dependência com o outro. Por esse motivo, o "eu", na sua forma individual, só pode existir através de um contato com o "outro". O reconhecimento dessa dialética da alteridade pode levar a que um indivíduo seja capaz de se colocar no lugar do outro, em uma relação baseada no diálogo e na valorização das diferenças existentes.

Para Suely Rolnik, a existência do outro tem efeito sobre nós: "[...] é na coexistência entre os corpos que se produzem turbulências e transformações irreversíveis em cada um deles." (ROLNIK, 1992, p. 3). A autora está, ainda, interessada em elaborar uma "ecologia da subjetividade" à qual é imprescindível para a conceituação política contemporânea de termos como "outro", democracia e cidadania.

Ela define "o outro" como tudo aquilo, humano ou não humano, unitário ou múltiplo, que é exterior a um eu. "Isso é o que se apreende no plano do visível, captável pela percepção: há nesse plano uma relação entre um eu e um ou vários outros (não só humanos, repito), unidades separáveis e independentes.” (ROLNIK, 1992, p. 3), que não se circunscreve só no plano da subjetividade do eu, muito menos se restringe àquilo que é visível e/ou material.

O outro, para a autora, nos arranca permanentemente de nós mesmos, gera estados inéditos que abalam a consciência subjetiva de nossa figura, balançam seu equilíbrio isto é, cada encontro com o outro faz uma reverberação naquilo que em nós é diferença (do outro, de nós mesmos), modificando nossa estrutura. Isso, por ser a alteridade dialética, relacional à nossa identidade:

\footnotetext{
A dimensão invisível da alteridade é o que extrapola nossa identidade - essa unidade provisória onde nos reconhecemos -, dimensão em que estamos dissolvidos nos fluxos e na qual se operam permanentemente novas composições que, a partir de um certo limiar, provocam turbulência e transformações irreversíveis no atual contorno de nossa subjetividade. (ROLNIK, 1992, p. 4).
} 
Assim, a alteridade é uma condição ou uma característica que se desenvolve por relações de diferença, de contraste. Posso afirmar que nossa biografia pessoal é desenvolvida por nossas relações interpessoais, pois é por meio da linguagem - esse recurso de expressão relacionada a pensamentos, percepções, desejos, e também de comunicação - que produzimos nossa maneira de perceber o mundo ao nosso redor e compartilhá-la em nossas comunidades.

Logo, é o discurso que cria o eu e o outro, mais além de ser uma ferramenta de percepção da realidade, como discutimos no capítulo anterior. Daí ser o discurso papel constitutivo de subjetividades e da própria alteridade, pois é através do discurso que muitas de nossas interações sociais se fazem possíveis - e também impossíveis, no limite de que o discurso é sempre circunstancial, provisório, instável, mesmo aqueles que se escondem sob fortalezas do estatuto narrativo, como os jurídicos, os religiosos (FOUCAULT, 2010, p. 22).

Para o autor, vivemos, aparentemente, sob o signo da logofilia, mas embaixo dessa presumida veneração do discurso existe um temor de que o discurso não seja dominável, coercível, e um desejo de que sua proliferação seja contida

\begin{abstract}
De modo a que sua riqueza fosse aliviada de sua parte mais perigosa e que sua desordem fosse organizada segundo figuras que esquivassem o mais incontrolável [...] Há, sem dúvida, em nossa sociedade e, imagino, em todas as outras, mas segundo um perfil e facetas diferentes, uma profunda logofobia, uma espécie de temor surdo desses acontecimentos, dessa massa de coisas ditas, do surgir de todos esses enunciados, de tudo o que possa haver aí de violento, de descontínuo, de combativo, de desordem, também, e de perigoso, desse grande zumbido incessante e desordenado do discurso. (FOUCAULT, 2010, p. 50).
\end{abstract}

Os discursos indesejados são aqueles que questionam as ordens sociais, como os discursos dos loucos, os que rompem, de uma ou outra forma, as lógicas estabelecidas nesse sentido é que se dá a violência, a combatividade: na ruptura com o mesmo, com o ordenamento.

Os sujeitos que ousam proferir tais discursos e refutam a ordem do discurso são, logo, também indesejados, sujeitos que rompem com a repetição - sujeitos outros, alterizados. A ordem do discurso é não só a ordem constitutiva de subjetividades, mas a da organização social, uma vez que "[...] o discurso não é simplesmente aquilo que traduz as lutas ou os sistemas de dominação, mas aquilo por que, pelo que se luta, o poder do qual nos queremos apoderar.", ou seja, o próprio objeto do desejo, não só aquilo que manifesta ou oculta o desejo (FOUCAULT, 2010, p. 10). 
Contra a ordem do discurso, a casualidade e o caos, a impermanência, a aposta na significação contextual, fincada na materialidade, a temível, a que, por mais que se tente, não se pode esquivar (FOUCAULT, 2010). Sob o signo da logofilia, que acoberta a logofobia, a tradução aparece como contravenção - ao logocentrismo, à razão do significante em si, desconexo e imaterial.

Porque a tradução chama essa busca e, ao mesmo tempo, recusa constante ao significado mais estável, único, exato. Mesmo os discursos com caráter de estatuto, que ganham o peso da tradicionalidade e da inquestionabilidade, tornam-se fugidios quando o jogo da tradução opera na linguagem. Assim, mesmo a narrativa totalizante da gênese bíblica é passível de desmonte e remontagem. A história presente no livro bíblico de Gêneses conta sobre a gênese do mundo e do homem e como o primeiro homem foi criado por Deus. Para RUIZ (2003, p. 71):

O termo Adam não designa - como vulgarmente se aceita - o homem varão. Ele é um termo com um sentido de coletividade; é um substantivo coletivo. Sua tradução mais correta seria a humanidade. [...] Iahweh não criou, num primeiro momento, o varão (aner), mas a humanidade. Esta humanidade ainda não tinha sido fraturada. Ela vivia numa unidade natural consigo mesma e com a natureza. Adam constitui uma mônada indivisível, que não tem alteridade. Ela não conhece a existência do outro.

A humanidade que admite forma vive sem o outro e, por isso, vivencia a solidão e "[..] sofre a impossibilidade de comunicar-se, pois não pode ir além de si mesma." (RUIZ, 2003, p. 71) Assim, será fraturada duas vezes, externa e internamente. A fratura externa é percebida na separação da humanidade, Adam, das outras espécies, as quais devem ser por ela nomeadas. No entanto, será necessária outra fratura: “[...] deverá rasgar a própria identidade de Adam. Esta segunda fratura vai significar, de fato, o desaparecimento de Adam como realidade autossuficiente e fechada em si mesma, dando lugar à gênese da intersubjetividade. " (RUIZ, 2003, p. 73).

Devido a essas fraturas e ao surgimento do outro, da comunidade, Adam, não pode existir mais isoladamente, assim como o outro tampouco pode viver sozinho. A partir daqui criamos uma relação de dependência para construirmos nossa identidade e nossa individualidade: a partir do encontro com a diferença, com o outro, e o caos que esse encontro pode significar (ROLNIK, 1992; FOUCAULT, 2010), no sentido de expor a fragilidade estruturante da identidade, a qual se contamina do contato com o outro.

Sendo fragilidade que se desmonta (para se remontar) através do outro. O encontro com o outro pode gerar também fertilidade: como a fertilidade das trocas que Bernd atribui "à perspectiva transcultural, dado que ela opera através do diálogo entre 
comunidades culturais, inaugura vias de reciprocidade nas relações culturais" (BERND, 2005, p. 149).

A autora ressalta que

O prefixo trans, que comporta as noções de ultrapassagem, de passar além, de sair de si mesmo, gera novas formas de conhecimento e de relação com o mundo, sendo portanto, mais performante, no incontornável contexto de mundialização no qual vivemos, do que inter(cultural), multi(cultural) ou re, como em reatualização, [...] pois o próprio processo da transculturação parece ser aquele que melhor se ajusta à realidade da condição pós-moderna onde há trocas, perdas e ganhos nas passagens de uma cultura à outra. (BERND, 2005, p. 149-150, grifo da autora).

Trans é o prefixo que, em alguns outros idiomas, traduz o termo tradução: translation em francês, translation em inglês. Destaca o imaginário da linguagem como translugar, porque é dinâmico, não-estável: é como uma areia movediça de significados profundos.

Temos que levar em consideração que quaisquer palavras que utilizamos para traduzir o outro estão restritas política-econômica-culturalmente, pois não existem palavras neutras para falarmos sobre o estranho. Isso se dá justamente por não sermos neutros, nem termos um olhar que seja desenraizado, pois são exatamente todos os nossos enraizamentos que constroem nossa relação com a alteridade.

Para Donna Haraway, é unicamente a perspectiva parcial, enraizada (o que ela chama de saber localizado) que permite haver alguma visão objetiva. Paradoxalmente, a objetividade não estaria em posicionar-se de um não-lugar descorporificado, mas precisamente de enunciar de que lugar se está, de onde se é:

\begin{abstract}
Precisamos aprender em nossos corpos, dotados das cores e da visão estereoscópica dos primatas, como vincular o objetivo aos nossos instrumentos teóricos e políticos de modo a nomear onde estamos e onde não estamos, nas dimensões do espaço mental e físico que mal sabemos como nomear. Assim, de modo não muito perverso, a objetividade revela-se como algo que diz respeito à corporificação específica e particular e não, definitivamente, como algo a respeito da falsa visão que promete transcendência de todos os limites e responsabilidades. (HARAWAY, 1995, p. 21).
\end{abstract}

Para a filósofa, as narrativas ocidentais que tematizam a objetividade "[...] são alegorias das ideologias das relações sobre o que chamamos de corpo e mente, sobre distância e responsabilidade", e seu projeto de objetividade feminista, ou saber localizado (o qual é pertinente a qualquer outro sujeito político localizado socialmente desde suas marcas identitárias identificadas como diferenças constitutivas naquela ordem do mesmo e do poder, sobre a qual discutiu Foucault), se trata “[...] da localização limitada e do conhecimento localizado, não da transcendência e da divisão entre sujeito e objeto. Desse 
modo podemos nos tornar responsáveis pelo que aprendemos a ver" (HARAWAY, 1995, p. 21).

Entre os discursos institucionais que têm estatuto de verdade, tradição e imutabilidade, o discurso científico e seu apelo à objetividade, à neutralidade conseguida às custas de uma supressão do sujeito no campo da construção do conhecimento, é um dos mais dominantes, e um dos grandes produtores de significados considerados inquestionáveis.

No entanto, essa perspectiva de objetividade sem sujeito cria monstruosidades, conhecimento feito sem responsabilização. $\mathrm{Na}$ era dos drones e das mutações genéticas modificando organismos em níveis do DNA, isso é preocupante. Haraway (1995, p. 19) propõe uma retomada da visão como metáfora não do distanciamento, do olho que tudo vê e em nenhum lugar se localiza, "visão direta, devoradora, generativa e irrestrita".

Mas uma visão também localizada, que parte de um sujeito desde seus olhos, contrária à "habilidade perversa" associada aos olhos, "[...] esmerilhada à perfeição na história da ciência vinculada ao militarismo, ao capitalismo, ao colonialismo e à supremacia masculina - de distanciar o sujeito cognoscente de todos e de tudo no interesse do poder desmesurado." (HARAWAY, 1995, p. 19).

Ela propõe que reaprendamos com nossos corpos; propõe uma retomada da visão como um sentido que pode ser resgatado para que encontremos um caminho a partir do aprendizado da corporeidade - a materialidade temível discutida por Foucault ao falar de discurso. A materialidade da subjetividade, dessa vez. Para ela, nossos olhos orgânicos “[...] são sistemas de percepção ativos, construindo traduções e modos específicos de ver, isto é, modos de vida." (HARAWAY, 1995, p. 22).

Haraway, em seu projeto de saber localizado em que a objetividade é assumidamente subjetiva, parcial, compromete sua produção teórica com “[...] um mundo que possa ser parcialmente compartilhado e amistoso em relação a projetos terrestres de liberdade finita, abundância material adequada, sofrimento reduzido e felicidade limitada." (HARAWAY, 1995, p. 16). Ou seja, é um projeto de re-ver, de transformação do mundo. Acredito que um projeto dessa magnitude está conectado de forma indissociável a transformações nos sujeitos: no eu, e no outro.

Como vimos anteriormente, há uma relação dialética entre eu e outro, relação na qual a mudança não só é inevitável, como é condição essencial do encontro. Assim como nos processos tradutórios textuais, em que a mudança é um traço incontornável, a 
tradução do outro traz consigo uma negociação de significados, a qual gera transformações quando temos que reconstruir outra comunidade diferente da nossa.

Sobre esse tema, Augé (1997, p. 96) escreve:

A linguagem da alteridade, que é a outra linguagem constitutiva da simbologia
social, situa-se sob o signo da ambigüidade, no sentido de ser ambígua uma
realidade que nem uma qualidade nem a qualidade contrária evocam com
propriedade, mas sim uma terceira, que não tem outra definição senão essa
dupla negação: não é nem boa, nem má. A linguagem da alteridade sugere que
a verdade dos seres está fora das identidades de classe. Ela relativiza sua
significação e levanta as questões em termos de implicação, de influência e de
relação. Enquanto a linguagem sócio-política da identidade estabelece as
relações entre um indivíduo e as diversas coletividades de que ele faz parte ou
não, a linguagem psicofilosófica da alteridade levanta a questão da relação
entre as pessoas ou, mais abrangentemente, da relação entre o mesmo e o outro.

Essa ambiguidade acaba por levar-nos a uma incerteza e indecisão com relação ao estranho e, como consequência, construímos a imagem do outro baseados nos nossos conhecimentos e no que nos é familiar, comparando-o e contrastando-o conosco mesmo, numa relação narcísica e até egoísta. No capítulo anterior, vimos como essa busca por familiaridade, no plano textual, discursivo ou subjetivo, está relacionada ao conceito de ortonímia discutido por Annie Brisset.

Para essa autora, a ortonímia significaria um (questionável) instinto tradutório, que levaria à necessidade de fazer "soar bem" o texto traduzido, independentemente das suas estruturas no idioma em que foi escrito (e no qual, muitas vezes, ele também "soa bem"). Essa discussão foi tematizada por outros teóricos da tradução como um embate entre a domesticação e a estrangeirização dos textos em tradução.

E esse é um debate que não diz respeito unicamente aos Estudos da Tradução, pois se reflete nas condutas aprendidas quando do encontro com o outro: ele vai ser por mim recebido em sua autenticidade, em sua diferença? $\mathrm{Ou}$, para compreendê-lo, preciso enquadrá-lo nos meus esquemas mentais de conhecimento, naquilo que posso conhecer e tornar inteligível? Isso leva à paradoxal questão de que o reconhecimento da diferença postula, ao mesmo tempo, distanciamento e empatia - reconhecer na própria natureza o que é estranho, e reconhecer no estranho o que é parte da natureza própria.

De novo, estamos face à dialética da alteridade, que se faz, assim, num jogo entre semelhanças e dessemelhanças, em que do equilíbrio entre ambas depende a possibilidade urgente de fuga dos dois paradigmas binários, excludentes e redutores que se tornam a domesticação e a estrangeirização.

Augé classifica a alteridade em três tipos, designadas por ele como alteridade completa, interna e íntima: 
Existe certamente a alteridade completa, a do estrangeiro ao qual se atribuem necessariamente todos os defeitos cuja existência se nega em si-mesmo. É para esse estrangeiro além das fronteiras que são projetadas, eventualmente, os fantasmas da ferocidade, do canibalismo, da desumanidade. [...] Há uma alteridade interna, a alteridade social, que é na verdade consubstancial ao social definido como sistema de diferenças instituídas: o sexo, a filiação, a posição na ordem dos nascimentos, a idade são tantos critérios diferenciais que compõem a trama do social e não deixam de ter expressão espacial. [...] Há finalmente a alteridade que eu proponho chamar-se de íntima porque ela atravessa a pessoa de cada indivíduo. [...] Por definição, o indivíduo é composto. (AUGÉ, 1999, p. 138-139).

Seguindo a conceituação do autor, podemos considerar que o estrangeiro que passa por uma mudança em termos geográficos, que realmente se muda do seu país para outro, está em condição de alteridade completa. Já na alteridade interna, percebemos o outro em relação a uma diferença social, seja de forma sócio-econômica, de gênero, de raça ou de idade.

Por último, na alteridade íntima, temos aqueles indivíduos que se percebem estrangeiros para eles mesmos. Esses três tipos de alteridade permitem que vejamos que não somente o estrangeiro de outro país é estranho aos nossos olhos, e que a relação com a tradução do outro está presente no nosso dia-a-dia, quando relacionamo-nos com qualquer pessoa e até conosco mesmo, desde conflitos externos a conflitos internos que passamos em nossas rotinas.

No entanto, essa estrangeiridade se multiplica quando temos contato com outros países, que acabam mostrando uma realidade diferente de forma mais latente aos nossos olhos, habituados com as mesmas paisagens culturais, subjetivas, e agora expostos a um contexto geográfico, cultural, social distinto.

Dessa maneira, quando refletimos sobre o conhecimento das particularidades da cultura de uma determinada língua que é traduzida, pode-se enxergá-la como um facilitador na busca da reexpressão, o qual reforça a importância que o conhecimento do contexto e da cultura têm no aprendizado da outra língua. E pensando no caso da tradução de um discurso, pela perspectiva da alteridade, não se trata de traduzir uma mensagem, mas de ressignificá-la para outra língua-cultura.

A cultura é "efeito das representações", ou seja, o mundo e a cultura não são estáveis, a sociedade e a ideologia são quem produzem os seus sentidos. O sistema de significação é socialmente estabelecido, e é por meio dele que vemos o mundo e o constituímos. Os valores e as ideias compartilhadas entre os falantes de determinada língua são regras apropriadas a uma situação específica, pois temos um determinado discurso dependendo do contexto em que estamos inseridos. 
Na tradução, a qual não é uma ciência exata, não se traduzem palavras isoladas, mas sim textos e contextos, com vários níveis linguísticos. Assim, é problemático encararmos a tradução como uma relação de equivalência, pois ela pratica a diferença entre valores, crenças, representações sociais... Pode, assim, funcionar como agente de domínio. Mas, por outro lado, pode operar como agente de hibridização cultural, conexão, integração. Por mais que os conflitos sejam esperados, pois fazem parte de qualquer contexto em que coexistam línguas:

[...] os acordos aos quais elas chegam são instáveis, pois são incessantemente renegociados ao sabor da evolução das relações de força que as opõem, e que interligam suas práticas linguísticas e discursivas a outros modos de organização social e institucional. (D'HULST; VANDEMEULEBROUCKE, 2013, p. 288).

A tradução se situa em um ponto intermediário, que não é o da transparência nem o da equivalência, pois cada signo se relaciona com os outros signos de modo diferente em cada língua e em cada texto de cada língua.

Octavio Paz, em seu livro "Traducción, Literatura y Literalidad", nos coloca que:

Por um lado, a tradução suprime as diferenças entre uma língua e outra; mas, por outro lado, revela-as mais plenamente: graças à tradução nós aprendemos que nossos vizinhos falam e pensam de uma forma diferente da nossa. (PAZ, 1972, p. 12, tradução minha ${ }^{10}$ ).

O autor complementa, explicando tradução de forma análoga à concepção de intertextualidade dialógica que vimos, no capítulo anterior, estar presente como tema fundamental na obra de Bakhtin:

Cada texto é único e, ao mesmo tempo, é a tradução de outro texto. Nenhum texto é literalmente original, pois a própria linguagem, em sua essência, é uma tradução: primeiro do mundo não-verbal e, depois, porque cada signo e cada frase é a tradução de outro signo e de outra frase. No entanto o raciocínio pode se inverter sem perder a validade: todos os textos são originais porque cada tradução é distinta, constitui um texto único. (PAZ, 1971, p. 13, tradução minha $\left.{ }^{11}\right)$.

O estranhamento do dito na outra língua pode ser vivido tanto como uma perda (até mesmo de identidade), como uma operação de renovação e de relativização da língua

\footnotetext{
10 "Por una parte la traducción suprime las diferencias entre una lengua y otra; por la otra, las revela más plenamente: gracias a la traducción nos enteramos de que nuestros vecinos hablan y piensan de un modo distinto al nuestro."

11 "Cada texto es único y, simultáneamente, es la traducción de otro texto. Ningún texto es literalmente original, porque el lenguaje mismo, en su esencia, es ya una traducción: primero, del mundo no-verbal y, después, porque cada signo y cada frase es la traducción de otro signo y de otra frase. Pero el razonamiento puede invertirse, sin perder validez: todos los textos son originales porque cada traducción es distinta, constituye un texto único."
} 
primeira, ou como a descoberta embriagadora de um espaço de liberdade. O "eu" da língua estrangeira não é, jamais, completamente igual ao da língua primeira.

Há quem evite qualquer distância em relação ao "eu" da língua primeira, rejeitando todo contato direto com a língua estrangeira. Frequentemente me deparo com alunos que procuram reduzir a aquisição da língua a procedimentos lógicos e somente podem compreender um enunciado em língua estrangeira se cada termo for traduzido para a língua primeira, conseguindo muito dificilmente assimilar as palavras e expressões da língua estrangeira que não têm equivalentes na língua primeira.

Revuz (2001, p. 229) propõe que:

Aprender outra língua é fazer a experiência de seu próprio estranhamento no mesmo momento em que nos familiarizamos com o estranho da língua e da comunidade que a faz viver. Há muitas maneiras de eludir essa experiência, porém, não será sempre entregar-se a um duplo desconhecimento: desconhecimento do Outro, da alteridade e desconhecimento de si e do próprio estranhamento?

A aprendizagem de línguas estrangeiras esbarra na dificuldade que há para cada um de nós em não somente aceitar a diferença, mas em explorá-la, fazê-la nossa, admitindo a possibilidade de despertar a complexidade de nossa própria diferença interna. Ducrot afirma que "[...] a língua, independentemente das utilizações que dela podem ser feitas, apresenta-se, fundamentalmente, como o lugar do debate e da confrontação das subjetividades." (DUCROT, 1987, p. 30).

A constatação de que língua estrangeira não recorta o real da mesma forma que a língua primeira impõe-se desde os primeiros momentos da aprendizagem e provoca, com frequência, surpresa e até escândalo no aprendiz. Por exemplo, as palavras que em espanhol são masculinas e em português femininas, e vice-versa; ou a afirmação que é expressa ao se dizer "Pois não"; ou a quantidade de falsos cognatos que nos enganam entre essas duas línguas.

Por isso acredito que, na verdade, o que desaparece com o contato entre línguas estrangeiras é a ilusão de que existe um ponto de vista único sobre as coisas, ou uma possível tradução termo a termo. Desaparece, assim, a ordem monolítica do discurso e, consequentemente, a pretensão de ordem monolítica, estável, una do sujeito, uma vez que esse é constituído naquele e está também suscetível às suas ambivalências (e vice-versa).

O sujeito traduzido se converte em um integrante de uma comunidade e passa a possuir novas visões de mundo e perspectivas. Assim, efetua escolhas dentro do repertório linguístico-cultural disponível e, ao vincular-se a circunstâncias sócio- 
históricas e temporais próprias, acaba mostrando traços autorais em sua leitura da realidade de forma singular.

Paulo Freire, em “A importância do ato de ler", aponta as conexões entre linguagem e realidade, as quais podem se configurar num desafio a ser sempre alcançado por quem deseja elaborar uma forma crítica de leitura do mundo e da palavra e, assim, ser também sujeito crítico no mundo. Segundo o autor, a leitura crítica da palavra e do mundo é uma que

[...] não se esgota na decodificação pura da palavra escrita ou da linguagem escrita, mas que se antecipa e se alonga na inteligência do mundo. A leitura do mundo precede a leitura da palavra, daí que a posterior leitura desta não possa prescindir da continuidade da leitura daquele. Linguagem e realidade se prendem dinamicamente. A compreensão do texto a ser alcançada por sua leitura crítica implica a percepção das relações entre o texto e o contexto. (FREIRE, 1989, p. 9).

O convite é a enxergar sempre o novo e buscar a diferença, mesmo com os olhos habituados pelo familiar. O familiar consiste em nossas concepções e opiniões em face de outros povos, culturas e ideologias, e inclusive sobre nós mesmos; ele abarca e delimita, segundo Gadamer (1999, p. 452). Tal ideia associa-se ao conceito gadameriano de horizonte, "o âmbito de visão que abarca e encerra tudo o que é visível a partir de um determinado ponto".

Ou seja, um horizonte nunca está completamente pleno ou finalizado, mas é sempre formado de um fluxo de modificação através dos deslocamentos dos nossos pontos de vista, transformados e ampliados pelo contato e pela relação com o elemento não familiar ou estranho. "A ausência de horizonte e, em decorrência, o desconhecimento do que a alteridade tem a oferecer, impede o indivíduo de ver suficientemente longe e leva-o, por conseguinte, a supervalorizar o que lhe está mais próximo" (GADAMER, 1999, p. 452). Isso consolida os conceitos preestabelecidos e estereotipados pela tradição. Precisamos de um horizonte cambiante, que se amplie e desloque rumo ao que é outro, não buscando apenas um acordo, mas talvez um conflito que nos enriqueça e nos mostre a importância da alteridade para a constituição do eu.

O encontro entre línguas é constantemente tenso:

Sabe-se que a coexistência das línguas torna-se uma fonte inesgotável de tensões a partir do momento em que diz respeito às práticas discursivas. Os equilíbrios que ela cria são sempre tênues, em um eixo que vai da ausência de qualquer integração entre as línguas em questão até a escrita bilíngue, transitando pelos diferentes graus ou modos da mistura de línguas, pela 
tradução e também por outros operadores intertextuais [...] (D’HULST; VANDEMEULEBROUCKE, 2013, p. 287).

Segundo Kramsch (1998, p. 6), os indivíduos são imersos em um "ritual invisível" que direciona suas escolhas e agrega a elas motivações associadas a visões de mundo e ideologias vigentes. A própria carga idiossincrática na interpretação vincula-se a um leque finito de possibilidades oferecidas pelo repertório linguístico e pela cultura disponível.

No plano da significação, essas possibilidades se conectam a partir do que se chama "campo associativo das palavras". Blecua aponta que cada palavra de um idioma evoca, na mente do sujeito, "um conjunto muito complexo de associações de diferentes naturezas" (BLECUA, 1979, p. 99). A complexidade do conjunto está também no fato de que o campo não diz respeito unicamente às palavras, mas extrapola-as e amplia-se em redes associativas igualmente complexas, nas quais um campo associativo é permeado de outros.

\begin{abstract}
Cada um dos elementos que compõe o esquema [associativo] traz seu próprio campo associativo, e por isso na linguagem os campos das palavras se cruzam até formarem redes bastante densas, como se tivessem fios e nós; assim os significados não podem ser estudados isoladamente, mas sim levando-se em conta este emaranhado conjunto. (BLECUA, 1979, p. 100).
\end{abstract}

$\mathrm{Na}$ escolha de recursos linguísticos para a construção de sua leitura, o sujeito do discurso traduzido inevitavelmente reflete em seu texto as concepções relativas à linguagem e aos gêneros textuais correntes em sua época, pois não é, como qualquer outro, inteiramente livre de coerções contextuais. Ao contrário, está imerso nessas coerções contextuais.

A relevância dos gêneros textuais é significativa para a argumentação que estou desenvolvendo aqui, pois é a partir deles que se organiza a produção de discursos em nossa sociedade, segundo Bakthin. Vivemos em uma sociedade letrada que se organiza em torno dos gêneros textuais, pois a língua é acessada em forma de enunciados orais ou escritos que são concretos, únicos e emanam dos falantes a partir de esferas diferentes das atividades humanas.

O autor assim apresenta a questão:

O enunciado reflete as condições específicas e as finalidades de cada uma dessas esferas, não só por seu conteúdo (temático) e por seu estilo verbal, ou seja, pela seleção operada nos recursos da língua - recursos lexicais, fraseológicos e gramaticais - , mas também, e sobretudo, por sua construção composicional. Estes três elementos (conteúdo temático, estilo e construção composicional) fundem-se indissoluvelmente no todo do enunciado, e todos eles são marcados pela especificidade de uma esfera de comunicação. 
Qualquer enunciado considerado isoladamente é, claro, individual, mas cada esfera de utilização da língua elabora seus tipos relativamente estáveis de enunciados, sendo isso que denominamos gêneros do discurso. (BAKHTIN, 1997 , p. 280, grifos do autor).

A organização dos gêneros também é dinâmica. Daí a ênfase em que os enunciados se apresentem em tipos relativamente estáveis. Gêneros textuais-discursivos entram e saem de uso de acordo com as necessidades dos grupos sociais que os articulam, sendo, portanto, criados, recriados, e às vezes mesmo substituídos ou suprimidos. Isso ocorre por sua própria natureza dinâmica e fundamente conectada ao discurso como uma prática social da linguagem.

As evoluções sociais e tecnológicas da atualidade têm significado, por um lado, o desuso de determinados gêneros (por exemplo, o telegrama), com relação ao surgimento e ao uso de outros. Por outro lado, vemos a uma renovação do repertório dos gêneros textuais-discursivos. Pois hoje temos, por exemplo, os gêneros torpedo, e-mail, twitt, ligados a avanços no sistema telefônico e de comunicação, a internet e a transmissão rápida de dados virtuais.

Alguns desses gêneros têm especificidade determinada não só pelas necessidades subjetivas dos sujeitos que compõem os grupos sociais em que se desenvolvem, mas também pelo meio de sua criação e desenvolvimento, como atesta o número máximo de caracteres que um determinado site comporta, como o twitter, rede social de compartilhamento de textos e notícias com o máximo de 140 caracteres.

As mudanças na organização dos gêneros textuais-discursivos também se posicionam de forma interconectadas às transformações culturais, transformações que são da e na linguagem. Assim, a tradução, que já foi aqui definida, entre outras características, como uma tecnologia da linguagem, também está relacionada a tais mudanças, sendo, ela própria, mutável, dinâmica, e suscetível às alterações no sistema de gêneros textuaisdiscursivos.

Para atestar esse caráter instável e dinâmico da tradução, basta ver a mudança da metafórica concernente a ela, estudada, por exemplo, por Chamberlain (2005) e Flotow (2013). Da estereotipada metáfora da tradução como bela infiel, ou seu imaginário do processo como reprodutivo, mecânico e repetitivo e também considerado como inferior (atribuição social dada a mulheres em várias sociedades, e foco de disputas discursivas e políticas) (CHAMBERLAIN, 2005), a contemporaneidade vê surgir metáforas da tradução como exercício de transformance, ou seja, tradução aliada à performance (FLOTOW, 2013). 
Na tradução como transformance, fica ressaltado seu caráter performativo e constitutivo da e na diferença textual e contextual de sujeitos autores em diálogo (quem traduz, tanto quanto quem se está traduzindo) - uma assunção da diferença entre "um" e "outro", "próprio/familiar" e "alheio/estranho", mas que não se fundamenta em hierarquizações tão assimétricas como a metafórica anteriormente discutida.

Wanderley (1994, p. 23) propõe que "a tradução é um ser permanentemente em curso", o qual norteia-se por um jogo de remissões que conduzem a um processo intertextual infinito, entre indivíduos, línguas e culturas. Esse processo é sobremaneira marcado pelas percepções de familiaridade e estranhamento que indivíduos experimentam entre si, entre seus grupos e com relação a outros grupos sociais em contato.

Como acrescenta Silva (2008), Gadamer e Derrida destacam a dicotomia familiar/estranho. A relação binária revela a interdependência e conjunção entre os termos. Essa tensão entre o familiar e o estranho, entre o eu e o outro, é determinada pelas coerções impostas pelas culturas, verdadeiras fronteiras construídas por visões de mundo que os indivíduos julgam naturais e incontestáveis. Adotadas pela comunidade interpretativa, tais exigências restringem os significados possíveis para a construção de interpretações, fatos que direcionam as escolhas feitas pelos sujeitos.

Uma abordagem crítica da alteridade nos mostra que, por causa de imagens e vivência anteriores, criamos padrões pré-estabelecidos de aceitação ou rechaço do outro, pois cada um tem seu próprio repertório psicossocial, cultural que compõe aquilo que conforma sua alteridade como constituinte de sua subjetividade. Assim, cada pessoa acaba julgando de forma individual os outros ao seu redor, os que são estrangeiros dentro da sua forma peculiar de ver o mundo.

Dessa forma, gostaria também de fazer um paralelo com a atividade tradutória, que está constantemente nos revelando diferentes alteridades mas, ainda assim, por vezes, queremos impor nossas formas de interpretar determinada situação dentro dos nossos parâmetros, sem pensar na relevância do que é diferente do nosso (e que nos propusemos a traduzir) em termos de representar importância no conteúdo expressivo de determinado discurso ou sujeito estrangeiro - ou, mais precisamente, estrangeirizado esse nosso próprio olhar.

Duschatzky e Sliar (2001, p. 122) destacam que:

[..] se a cultura é, de acordo com Bhabha (1994, op. cit.), um território de diferenças que precisa de permanentes traduções, o problema crucial é quem 
traduz a quem (ou quem representa a quem) e através de quais significados políticos. Disso resulta que a tradução e representação dos outros está atravessada por uma busca permanente de eufemismos, melhores (ou piores) formas de denominar a alteridade. Não obstante, essas formas não são neutras nem opacas e geram conseqüências na vida cotidiana desses outros.

Por isso, a consciência da nossa limitação em relação a uma visão parcial do outro é essencial para os Estudos da Tradução, para que não tomemos o outro simplesmente pelo que vemos, escutamos ou lemos, mas sim, possamos perceber nossa incompletude ao traduzir e julgar outra cultura, pois não temos acesso a uma visão neutra.

Como o eu é formado por essa interlocução constante com muitos outros, nossa biografia é formada por nossa relação com os que compõe tanto nossa alteridade interna como externa. Como temos visto, não há como abordar o tema da alteridade sem falar também de identidade.

\subsection{TRADUZINDO A IDENTIDADE:}

"El lenguaje se vuelve paisaje y este paisaje, a su vez, es una invención, la metáfora de una nación o de un individuo.” (PAZ, 1971, p. 17).

O conceito de identidade é muito complexo e contemporâneo e, para Stuart Hall (2006), é perceptível a existência de uma espécie de deslocamento duplo, um processo em que os indivíduos se descentram dos âmbitos seguros como o lugar por eles ocupado no mundo social e cultural, e ainda em si mesmos. Esse deslocamento é visto pelo autor como constitutivo de uma "crise de identidade" para o indivíduo, e é a partir dessa crise que identidades, antes sólidas, inquestionáveis, tornam-se problemas.

Bastos compreende identidade "[...] como uma construção social que envolve um processo dinâmico e situado de expor e interpretar quem somos" (BASTOS, 2008, p. 98). Assim como há a relevância do contexto para a conformação da linguagem, também as identidades sociais são dialógicas em relação ao mundo que circunda os sujeitos.

A noção de sujeito sociológico refletia a crescente complexidade do mundo moderno e a consciência de que esse núcleo interior do sujeito não era autônomo e autossuficiente, mas era formado na relação com outras pessoas e/ou núcleos sociais 
importantes para ele. A interação entre o "eu" e a sociedade era o espaço em que se dava a percepção e a constituição de sujeito: o mundo do trabalho, as relações familiares, a nação (HALL, 2006, p. 11).

Com as transformações sociais da contemporaneidade, a explosão de muitas categorias identitárias que foram, até cerca dos anos 1970, silenciadas ou invisibilizadas sistematicamente, notou-se também uma profunda mudança no sujeito considerado a partir de uma identidade unificada e estável. Cada vez mais, este sujeito está se tornando fragmentado, com várias identidades - seus traços se colocam ora em relação, ora em conflito.

O próprio processo de identificação, através do qual nos projetamos em nossas identidades culturais, tornou-se mais provisório, variável e problemático, e está relacionado à produção do sujeito pós-moderno, que é aquele sem uma identidade fixa, a qual é formada e transformada continuamente. À medida que os sistemas de significação e representação cultural se multiplicam, somos confrontados por uma multiplicidade de possíveis identidades.

Assim, a identidade é algo formado, ao longo do tempo, através de processos inconscientes, e não algo inato ou existente na consciência no momento do nascimento. Ela permanece sempre incompleta, "em processo", sempre "sendo formada". Em vez de falarmos em identidade como uma coisa acabada, deveríamos falar de identificação, e vêla como um processo em andamento; uma falta de inteireza que é "preenchida" a partir de nosso exterior, pelas formas através das quais nós imaginamos ser vistos por outros.

Stuart Hall postula que “[...] os significados das palavras não são fixos, numa relação um a um com os objetos ou eventos no mundo existente fora da língua. $\mathrm{O}$ significado surge nas relações de similaridade e diferença que as palavras têm com outras palavras no interior do código da língua.” (2006, p. 40). Segundo o autor, é assim que se torna observável uma relação existente entre língua e identidade: em saber quem sou "eu” em relação com "o outro".

Hall retoma a tese lacaniana segundo a qual a estruturação da identidade, assim como a do inconsciente, se dá como na língua. Hall remonta ainda à influência do pensamento saussureano na argumentação de Derrida, para quem um falante individual tem sempre que lidar com a "multimodulação" das palavras e, logo, não tem a possibilidade de fixação do significado como uma forma final, pois as palavras "sempre carregam ecos de outros significados" (HALL, 2006, p. 41). 
No mundo moderno, as culturas nacionais em que nascemos se constituem em uma das principais fontes de identidade cultural. Quando nos definimos como brasileiros, ou argentinos, ou espanhóis, estamos falando de forma metafórica, pois essas identidades não estão impressas em nossos genes. Entretanto, nós pensamos nelas como se fossem parte de nossa natureza essencial, mas, na verdade, são formadas e transformadas no interior da "representação".

A formação de uma cultura nacional cria, entre outros traços constitutivos, padrões de alfabetização, gera uma língua vernácula como meio dominante de comunicação, e contribui para uma cultura homogênea. Uma cultura nacional é um discurso, ou seja, um modo de construir sentidos que influencia e organiza tanto nossas ações quanto concepções que temos de nós mesmos.

Ao produzir sentidos sobre a nação, sentidos com os quais podemos nos identificar, construímos identidades. Benedict Anderson (1983, apud HALL, 2006) diz que a identidade nacional é uma comunidade imaginada, e que as diferenças entre as nações residem nas formas diferentes pelas quais elas são imaginadas.

Homi Bhabha (1990, apud HALL, 2006) aborda a "narrativa da nação", a qual fornece histórias, imagens, panoramas, cenários, eventos históricos, símbolos e rituais nacionais que simbolizam ou representam as experiências partilhadas. Nós, seres humanos, por sermos seres políticos, necessitamos também fazer parte de algum grupo, de pertencer a alguma comunidade.

Isto se reflete no sentimento de identidade nacional, no orgulho ou não de fazer parte de certa nação. Além disso, na contemporaneidade, criam-se identidades culturais que não são fixas, que estão suspensas, em transição. Hall aponta cinco marcos que permitiram essa reconfiguração das identidades na contemporaneidade: o marxismo, a teoria psicanalítica de Freud, a linguística estrutural de Saussure, a "genealogia do sujeito moderno" de Foucault e as teorias feministas (2006). Cada proposição, à sua forma e com os amplos desdobramentos históricos, políticos, sociológicos que todas elas geraram e ainda geram, romperam com a noção de unidade do sujeito e permitiram o surgimento de um sujeito híbrido.

Hall relaciona essa hibridez identitária aos processos de tradução cultural constantes que os sujeitos impactados pelas consequências dos trânsitos e mudanças globais realizam:

A categoria da identidade não é, ela própria, problemática? É possível, de algum modo, em tempos globais, ter-se um sentimento de identidade coerente 
e integral? A continuidade e a historicidade da identidade são questionadas pela imediatez e pela intensidade das confrontações culturais globais. Os confortos da Tradição são fundamentalmente desafiados pelo imperativo de se forjar uma nova auto-interpretação, baseada nas responsabilidades da Tradução cultural [...]. (HALL, 2006, 84).

As fronteiras, portanto, são atravessadas e intersectadas por um sujeito cada vez mais híbrido no realçar das formações de sua identidade fragmentada, em contato com culturas outras que não só o alterizam - mas também são alterizadas por ele. Assim, aumentam-se as negociações culturais dentro dessas fronteiras, pois não há espaço para apenas assimilação identitária. Essas pessoas:

[...] carregam os traços das culturas, das tradições, das linguagens e das histórias particulares pelas quais foram marcadas. A diferença é que elas não são e nunca serão unificadas no velho sentido, porque elas são, irrevogavelmente, o produto de várias histórias e culturas interconectadas [...] Elas estão irrevogavelmente traduzidas. (HALL, 2006, p. 88-89).

Hall também retoma a etimologia da palavra "tradução", apontando suas origens latinas de significado "transferir", "transportar entre fronteiras". O teórico considera que os migrantes, por pertencerem a dois mundos ao mesmo tempo, tornam-se sujeitos traduzidos, e para ele isso é o produto das novas diásporas configuradas pelas migrações pós-coloniais. É parte das identidades desses sujeitos o aprendizado de habitar identidades diferentes, falar duas linguagens culturais, e os processos constantes de tradução e negociação entre elas.

Por vezes nos deparamos com lutas internas entre vários perfis identitários. Outras vezes, há um imperativo externo para que um traço identitário seja preponderante a outro. Audre Lorde argumenta que essa fragmentação externa de identidades múltiplas "é a morte":

[...] sempre vai haver alguém tentando usar uma parte de seus eus, e ao mesmo tempo te encorajando a esquecer ou destruir todos os outros eus. E eu alerto vocês, isso é morte. Morte a você enquanto mulher, morte a você enquanto poeta, morte a você enquanto ser humano. [...] Quando o desejo por definição, próprio ou ao contrário, vem de um desejo por limitação em vez de um desejo por expansão, nenhuma face verdadeira pode emergir. (LORDE, 2015).

O que essa "morte", que no plano simbólico pode significar a dificuldade de articulação e expressão da própria subjetividade em um contexto de aprendizado de língua estrangeira, pode nos dizer desses contextos? Qualquer tentativa para aprender outra língua vem questionar e modificar aquilo que está dentro de nós com as palavras da primeira língua - ou, num sentido metafórico, permite um renascimento dentro daquela nova língua, com relação à primeira. 
Segundo Ellis (1997, p. 3), o termo "segunda" língua ou "L2" diz respeito à aprendizagem de qualquer outra língua após a aquisição da língua primeira, e esta pode ser uma terceira ou quarta língua. Também não importa se a nova língua é "adquirida" naturalmente, como resultado de se viver num outro país onde ela seja falada, ou "aprendida" na sala de aula, por meio de uma instrução específica.

Correntes socioconstrucionistas, pós-estruturalistas, concebem o indivíduo como um ser multifacetado, mutante, capaz de assumir não apenas uma, mas várias identidades que vão sendo construídas na sua interação com o Outro e com o meio social, sempre num constante estado de fluxo (MOITA LOPES, 2003). Assim, o sujeito constrói identidades múltiplas.

Somos dependentes de circunstâncias particulares, isto é, dos sentidos que os participantes dão a si mesmos e aos outros ao interagirem, por meio da língua, nas diferentes situações. "O indivíduo não tem uma identidade fixa anterior”, mas a constrói na língua e por meio dela (RAJAGOPALAN, 1998, p. 41), na sua relação com o Outro e com o meio social imediato.

Como nos propõe Lúcia Gonçalves de Freitas (2008), quando os aprendizes de uma segunda língua falam, eles não estão apenas trocando informações, mas organizando e reorganizando constantemente seu autoconhecimento, suas noções sobre quem são e como se relacionam com e no mundo social.

A mudança, as ocupações profissionais ou, às vezes, a falta destas faz com que muitos estrangeiros percam o status social e profissional que possuíam em seu país. Isso pode significar influência negativa ao aprendizado da língua portuguesa, pois o contato com essa língua que trouxe mudanças às vezes negativas na vida dos estrangeiros acaba sendo marcado por uma situação de trauma e, assim, despertar pouco interesse ou mesmo aversão - como forma de resistência cultural e linguística.

Vemos exemplos assim com filhos de diplomatas ou adidos militares, que acabam vindo obrigados para o Brasil por causa do emprego dos pais, ou no caso dos refugiados, que chegam de forma extremamente conturbada ao país. Muitas vezes, para esses sujeitos, aprender o novo idioma pode significar render-se. Bell Hooks analisa essa questão no contexto da diáspora afro-americana que inaugurou o período colonial das américas.

Hooks (2008) discute que o processo de sequestro e escravização de pessoas negras, obrigadas a cruzar o oceano Atlântico do continente africano até o americano, significou não só um conjunto de violências físicas, mas também simbólicas, 
especialmente no que tange às línguas faladas por pessoas diferentes, de etnias diferentes, que eram separadas de seus grupos sociais e familiares e misturadas a outras que falavam línguas diferentes - uma ferramenta, dos colonizadores, de dominação, impossibilitando uma articulação cultural entre os sujeitos desolados.

A autora diz que uma das estratégias de resistência à colonização foi, nesse sentido, o aprendizado da língua do colonizador, para que se tornasse possível o estabelecimento da comunicação entre as pessoas negras escravizadas, e uma rearticulação no ambiente inóspito geográfica, cultural, racial, epistemologicamente. Ela discorre que, num primeiro momento, apresenta resistência à ideia de uma "língua do opressor", pois esse seria um construto com o potencial desempoderador com relação às pessoas que "[...] apenas começaram a aprender a falar, que apenas começaram a aprender a reivindicar a língua como um lugar onde nós fazemos de nós mesmos sujeitos. 'Esta é a língua do opressor, no entanto eu preciso dela para falar com você'.” (HOOKS, 2008, p. 858).

E continua:

Somente como mulher adulta comecei a pensar sobre essas pessoas negras com relação à língua, pensar sobre seu trauma de serem forçadas a testemunhar sua língua se tornar sem sentido na cultura européia colonizadora, onde vozes julgadas estrangeiras não poderiam ser faladas, eram línguas fora da lei, fala renegada. Quando me dei conta de quanto tempo tinha levado para os americanos brancos reconhecerem as diferentes línguas dos americanos nativos, aceitarem que a fala que seus ancestrais colonizadores declararam ser meramente grunhidos ou cuinchos era de fato língua, é difícil não ouvir sempre no inglês padrão o som de massacre e conquista. Eu penso agora no pesar de africanos deslocados "sem casa", forçados a habitarem um mundo onde eles viam pessoas como eles mesmos, sob a mesma pele, a mesma condição, mas que não tinham uma língua compartilhada para falar um com o outro, que precisaram da "língua do opressor". "Esta é a língua do opressor, no entanto eu preciso dela para falar com você”. (HOOKS, 2008, p. 858).

Em sua teorização, Hooks nos fornece elementos para pensar a dimensão histórica e geopolítica do que, nos dias atuais, pode aparecer sob outras formas de "desconforto" linguístico, ou aberta resistência, quando se trata do ensino e aprendizagem de uma nova língua, dimensão essa que ganha grande relevância no contexto das américas em que a herança colonial ainda hoje se faz presente em diversas práticas culturalizadas de discriminação racial contra povos negros e indígenas.

A partir dos subsídios teóricos que Hooks fornece, proponho uma aproximação com a discussão começada anteriormente, para que assim reflitamos sobre as diversas crenças e insistentes que afirmam que a melhor forma para se aprender outra língua é viver no país em que esta seja falada majoritariamente. Se não é levada em consideração 
a complexidade das relações intra e interpessoais ocorrentes no contexto social, relações estas que são marcadas por organizações socioculturais e políticas como as categorizações de raça, de gênero, de classe, essas crenças tornam-se mitos.

No entanto, esses mitos vão se desencontrar da realidade de sujeitos em situação de contato/conflito gerada pela imersão em uma nova língua-cultura. Um exemplo atual desse processo, e suas consequências negativas para os sujeitos, é a situação de crianças hispano-falantes oriundas de migração por pobreza de países como Equador e Bolívia.

Elas vêm para o Brasil com suas famílias (as mães e pais serão, muitas vezes, mão de obra semi-escravizada na indústria têxtil brasileira) e, nas escolas brasileiras, ficam à margem dos processos de ensino e aprendizagem por estigmatizações de várias ordens (inclusive com relação à sua descendência indígena) e a dificuldade de inserção em um contexto educacional que não tem abordagem bilíngue. São, assim, forçadas a aprender um idioma de uma cultura que não as recebe bem em nenhum aspecto.

Pesquisas relacionando o rendimento escolar de crianças em escolas que atendem a esse público seriam importantes, desde que se aprofundassem em aspectos qualitativos além dos quantitativos que geralmente as orientam. Abordando essa problemática de forma aprofundada, permitiria uma compreensão atual do impacto das tensões suscitadas pelas línguas em contato em situação de imersão estrangeira, marcada por classe e raça/etnia.

Assim, temos mais um exemplo de que viver no país onde se fala a língua-alvo não garante ao indivíduo o acesso às interações com o falante nativo, supostamente o fornecedor "ideal" de input para o aprendiz de segunda língua. Por isso, acredito que a sala de aula deve ser um espaço em que não somente se trabalhe a "outra" língua, mas também onde se defrontem todos os "outros" que a ela se vinculam.

A tradução tem sido um dos veículos mais tradicionais de construção desse tipo de representação de culturas estrangeiras. É muitas vezes pela tradução que textos, literários ou não, circulam entre culturas diferentes, "apresentando" uma cultura a outra - em uma relação, muitas vezes, unidirecional.

Mas ela também pode colaborar para a formação de atitudes domesticadoras em relação a países estrangeiros, valorizando ou não etnias, raças e nacionalidades, com o acionamento de atitudes que sejam capazes de incentivar, por um lado, o respeito pela diferença cultural, ou, por outro lado, o ódio baseado no etnocentrismo ou no racismo. A 
tradução pode produzir uma mudança na forma como uma cultura estrangeira é representada.

Para Lawrence Venuti (2002, p. 148):

A tradução forma sujeitos domésticos por possibilitar um processo de espelhamento ou auto-reconhecimento: o texto estrangeiro torna-se inteligível quando o leitor ou a leitora se reconhece na tradução, identificando os valores domésticos que motivaram a seleção daquele texto estrangeiro em particular, e que nele estão inscritos por meio de uma estratégia discursiva específica.

O autor ressalta, também, a relação entre identidade e língua ao explicitar que a tradução geralmente se dá num contexto em que a população nativa está "[...] inscrita em escolhas discursivas específicas que funcionam tanto para criar uma identidade subordinada como para fazê-la parecer natural ou óbvia” (VENUTI, 2002, p. 13). Isso resulta na tradução como um embate cultural que, a partir de uma leitura, uma interpretação, remodela um texto de acordo com a cultura de chegada como condição de inteligibilidade:

Uma tradução sempre comunica uma interpretação, um texto estrangeiro que é parcial e alterado, suplementado com características peculiares à língua de chegada, não mais inescrutavelmente estrangeiro, mas tornado compreensível num estilo claramente doméstico. As traduções, em outras palavras, inevitavelmente realizam um trabalho de domesticação. Aquelas que funcionam melhor, as mais poderosas em recriar valores culturais e as mais responsáveis para responder por tal poder, geralmente engajam leitores graças às palavras domésticas que foram de certo modo desfamiliarizadas e se tornaram fascinantes devido a um embate revisório com o texto estrangeiro. (VENUTI, 2002, p. 18).

Para Berman (2002), a tradução autêntica (“ou seja, sem etnocentrismo”, p. 43) tem como objetivo limitar essa negação etnocêntrica encenando uma abertura, um diálogo, uma hibridização, um descentramento, e portanto levando língua e cultura domésticas a registrarem a estrangeiridade do texto estrangeiro:

Instituir um equilíbrio, uma medida nessa dimensão, operar uma tarefa de diferenciação. Ou antes, a poesia, o canto, instaura "o que permanece" ("Memória"), ou seja, essa dimensão diferenciada na qual a experiência do estrangeiro e a experiência do próprio conseguem ser dominadas. A poesia pode desempenhar esse papel de fundação porque ela é linguagem, letra e signo, porque ela resiste [...] (BERMAN, 2002, p. 295-296).

O autor está analisando, especificamente, as traduções que Hölderlin fez de poesia grega clássica para o alemão. As traduções são percebidas como estando no movimento entre línguas, com ênfase para as raízes dialetais do alemão e para a relação entre constituição de uma língua nacional alemã (identidade hegemônica) e essas raízes que as conformam em língua primeira sendo, paradoxalmente, suas mães. 
Para Berman, só é possível haver uma relação, e não uma domesticação, nesse encontro de línguas, em que a poesia grega é traduzida por Hölderlin para o alemão dialetal, porque a poesia é uma dimensão “[...] do Diferenciado, do Articulado, do Medido, [que] só pode ter como elemento a língua comum: ou seja, essa língua que se delimitou ao mesmo tempo em relação aos dialetos que ela 'encobre' sem os sufocar e em relação às outras línguas.” (BERMAN, 2002, p. 298).

Ele explicita, ainda, a dialogia bakhtiniana presente nessa relação, para enfatizar que a identidade da língua que traduz o grego, o alemão dialetal de Hölderlin, se forja justamente na diferença com o grego e nas próprias diferenciações internas (dialetais): “Pelo ‘diálogo' com o grego e o 'retorno' ao elemento dialetal do alemão, a poesia faz a língua comum ter acesso à sua dimensão própria, a essa dimensão de equilíbrio entre a língua estrangeira e o dialeto que é sua origem.” (BERMAN, 2002, p. 2999).

A tradução é ressaltada como um espaço de mestiçagem, em que “[...] há certamente acoplamento de línguas, mas estas, misturando-se, manifestam também sua pura diferença." (BERMAN, 2002, p. 309). Assim, fica referendada a interconexão entre identidade e alteridade no plano discursivo, a partir da tradução como uma prática que pode funcionar como dialogia e política (e poética) da diferença. Para Paulo Ottoni, essa “[...] prática da diferença só se efetiva na tradução se pensarmos não só na multiplicidade das línguas, mas também no que essa multiplicidade encena: a tradução recíproca na produção e transformação infinita de significados.” (OTTONI, 2005, p. 19).

Berman defende que a tradução deve participar de um movimento amplo de descentralização e mudança pelo qual as culturas literárias letradas do ocidente precisam passar, e continua: "Nenhuma 'teoria' do traduzir seria necessária se alguma coisa não devesse mudar na prática da tradução.” (BERMAN, 2002, p. 43). As raízes etnocêntricas que fundamentam as práticas tradicionais de tradução produzem uma das maiores fontes das tendências deformadoras da tradução que o autor discute (2013).

Para ele, o etnocentrismo é definido como aquilo “[...] que traz tudo à sua própria cultura, às suas normas e valores, e considera o que se encontra fora dela - o Estrangeiro - como negativo ou, no máximo, bom para ser anexado, adaptado, para aumentar a riqueza desta cultura" (BERMAN, 2013, p. 39). Assim, o etnocentrismo em tradução se traduz como domesticação, dominação. Uma manobra de hierarquizar as importâncias de quem está em contato, bem como de também criar valorização ou desvalorização das línguas em contato. 
Berman também explicita que tradução é experiência, das obras, das línguas, e do ser-das-obras e do ser-das-línguas (2013). Assim, é uma experiência inequivocamente humana, e por isso mesmo plural. Aquele encontro de subjetividades em que identidade e alteridade, língua e discurso, se articulam de forma ambígua, complementar, conflitiva.

No capítulo seguinte, a partir da análise de minha prática docente e de minha experiência acadêmica, pretendo refletir sobre as questões teóricas e práticas levantadas no presente estudo à luz da experiência compartilhada com esses outros sujeitos os quais convidei para tornar esse um texto mais plural, e com mais subjetividades. Fiz isso compreendendo as possibilidades, os desafios e as questões metodológicas próprias e consoantes a essa concepção cultural da tradução.

Para concluir o presente capítulo, gostaria de apresentar um questionamento que faz Berman, justamente sobre a abrangência e amplitude do termo Tradução, ressaltando inclusive seu viés subjetivo. Pois claro que tradução é passagem de uma língua a outra, contudo, não devemos nos restringir somente a essa noção do termo traduzir e da tarefa do tradutor:

Mas tem mais: ir além do sentido, inerente ao termo "tradução", a respeito do qual se fala muitas vezes de "tradução restrita" e de "tradução generalizada". Meschonnic criticou vigorosamente este ir além do sentido, tal como se encontra em Steiner e Serres. E é verdade que é necessário "manter" a tradução restrita (interlínguas), pois é ali, rigorosamente falando, que há tradução. No entanto, isto não deve nos impedir de escutar e de falar correntemente (quando se emprega "metaforicamente" o termo tradução, o que ocorre todos os dias), e toda uma geração de escritores e de pensadores, de Hamann a Proust, Valery, Roa Bastos, Pasternak, Marina Tsvetaieva etc, para quem a tradução significa não somente a "passagem" interlingual de um texto, mas — com esta primeira "passagem" - toda uma série de outras "passagens" que concerne ao ato de escrever e, mais secretamente ainda, ao ato de viver e de morrer. (BERMAN, 2013, p. 28-29). 


\title{
CAPÍTULO 3 - IDENTIDADES ALTERADAS
}

\begin{abstract}
Não atingimos nunca o homem separado da linguagem, não o vemos nunca a inventando. Não atingimos jamais o homem reduzido a si mesmo e procurando conceber a existência do outro. É um homem falando que encontramos no mundo, um homem falando com outro homem, e a linguagem nos ensina a própria definição do homem.

Émile Benveniste
\end{abstract}

\subsection{O ANTES}

Como nos propõe Berman em A prova do estrangeiro, "Falar é traduzir - de uma língua angelical para uma língua humana, ou seja, transpor pensamentos em palavras coisas em nomes - imagens em signos. " (Berman, 2002, p.33).

Estar no Brasil, com diferentes razões, por diferentes períodos de tempo, com diferentes níveis de conhecimento da língua, faz com que cada pessoa tenha uma experiência singular, mostrando-nos assim a individualidade da alteridade e da mudança que ocorre em cada um, que neste capítulo, fica presente na fala de cada entrevistado.

Ao referir-se à tradução como experiência, Heidegger diz:

\begin{abstract}
Fazer uma experiência com o que quer que seja [...] quer dizer: deixá-lo vir sobre nós, que nos atinja, que caia sobre nós, nos derrube e nos torne outro. Nesta expressão, "fazer" não significa em absoluto que somos os operadores da experiência; fazer quer dizer, aqui, passar, sofrer do início ao fim, aguentar, acolher o que nos atinge ao nos submetermos a ele... (HEIDEGGER, 1983, apud BERMAN, 2013, p.23)
\end{abstract}

E assim pode ser a experiência de vivenciar outra língua-cultura, de tornar-se outro diante dos olhos dos que nos rodeiam e aos nossos próprios olhos, acolhendo o que nos atinge, submetendo-nos ao que é estranho e permitindo que o outro nos modifique.

Dessa maneira, quando pensei no critério de escolha dos convidados a serem entrevistados, o primeiramente me baseei no tempo que eles tinham no Brasil, pois não queria entrevistar pessoas que haviam acabado de chegar ao país ou que tivessem um nível muito básico de português, senão o entrevistado ficaria muito preocupado em não cometer erros de português, e a conversa acabaria sendo mais uma comparação das dificuldades estruturais entre o par de línguas em questão, ao invés de enfatizar a questão identitária, que é o objeto do presente trabalho. 
Por isso resolvi conversar com pessoas que estão com um nível mais avançado de língua portuguesa, para que não se preocupassem tanto com a língua em que a entrevista estava sendo feita, mas sim com os temas discutidos nesta. Além disso, com mais tempo no Brasil, as pessoas puderam dar um relato mais abrangente da visão que têm do país e da língua-cultura brasileira.

Em segundo lugar, pensei em escolher pessoas que tivessem diferentes perfis e relações com o Brasil, para comparar as opiniões daqueles que vêm para estudar, trabalhar ou acompanhar o seu marido ou esposa, com a finalidade de ver como isso influencia também a identidade que está sendo construída aqui e na visão que o indivíduo tem do local em que está.

As transcrições das entrevistas são apresentadas de forma literal no trabalho, sem correção dos desvios quanto à norma culta do português cometidos pelos participantes ou da influência de outros idiomas na entrevista. Como o foco do trabalho não era verificar o nível formal de português, optei por deixar as transcrições o mais próximo da realidade. Além disso, acredito que, se corrigisse os erros, poderia alterar a forma que o leitor deste trabalho construirá a imagem do entrevistado, por isso deixei como marca de cada um. As transcrições completas das entrevistas estão nos anexos do trabalho e, para o presente capítulo, fiz um recorte com as partes que mais dialogam com o objetivo da pesquisa.

Nas perguntas feitas e no recorte feito nas entrevistas, busquei destacar os contextos de origem e os contextos onde os entrevistados estão vivendo no Brasil; o interesse pela língua-cultura brasileira; onde aparece a língua-cultura do entrevistado; como é a nova identidade do entrevistado no Brasil; e se o conhecimento apenas da estrutura da língua provocaria o sucesso na inserção na sociedade.

\subsection{O DURANTE}

Ao começar a entrevista, em primeiro lugar, eu pedia para que as pessoas se apresentassem, descrevendo quem eles eram e como foram seus percursos até chegar ao Brasil. Assim, queria que eles falassem sobre sua profissão, sobre o que haviam estudado, em quais países viveram, quais línguas falam, e o porquê de terem vindo para o Brasil, para, dessa maneira, poder conhecer melhor a pessoa, seu perfil, seus caminhos e perspectivas. 
Após isso, pedia para que elas falassem como eram suas vidas antes de vir para cá e como está sendo aqui, para perceber a diferença que existe no meio onde ela está vivendo e a influência deste meio na vida e na formação da sua identidade no Brasil, pois temos pessoas que se mudam por causa do emprego do marido, ou da esposa, e acabam abrindo mão de sua vida no seu país por causa deles, muitas vezes largam empregos e amizades em prol do companheiro ou companheira. Em outras situações, o indivíduo vem sozinho para estudar ou trabalhar no Brasil, e já tem outra visão dessa situação.

Como alguns dos entrevistados estão no país apenas de passagem e outros vieram para ficar, quis esclarecer tal situação, por isso perguntei quanto tempo cada um pretendia ficar no país, ou se pretendia morar aqui sem um prazo determinado, pois dependendo do tempo que a pessoa passará no Brasil, poderia haver uma influência na forma como ela lida com o país, a maneira como se entrega à cultura e aos costumes, podendo estar sempre com uma visão estrangeira do lugar, ou querer se moldar aos costumes e cultura locais, para adaptar-se melhor e conhecer mais o meio onde está vivendo.

Em seguida os questionava quanto às suas percepções do Brasil, o que gostavam, o que não gostavam, quais estranhamentos tiveram com a língua, ou com a cultura e a culinária. Com esta pergunta queria perceber quais pontos eram relevantes para esse indivíduo, o que ele destacava como algo bom ou ruim em uma nova língua-cultura. Assim deixava aparecer o seu ponto de vista, o que destacava e o que omitia.

Após isso, eu lhes perguntava qual era sua relação com a língua portuguesa e se eles se sentiam à vontade falando essa língua. A pergunta visava levantar o questionamento de se eles sentiam o português ainda como uma língua muito estrangeira, muito estranha, ou se já se haviam familiarizado, já a sentiam como algo que pertence a eles, já mais próxima. E, seguindo essa questão, perguntava em quais situações eles falavam português no seu dia-a-dia, pois há muitas pessoas que moram no Brasil, porém falam a sua língua primeira o tempo todo, em casa, no trabalho, nas reuniões de amigos. E muitas só têm amigos estrangeiros, e não se relacionam nem se integram à comunidade local.

Seguindo nessa linha, eu lhes questionava se já haviam tido alguma situação, ou algum tema, no qual eles se sentiam mais à vontade, mais livres, para se expressar em português do que em espanhol, ou se sempre se sentiam mais cômodos falando espanhol. Essa pergunta foi muito interessante para perceber como cada um se relacionava tanto 
com a língua quanto com a cidade e com essa mudança em suas vidas, e se já estavam totalmente confortáveis ou não falando o português do Brasil.

Por último, questionava se eles achavam que a língua portuguesa havia mudado algo neles ou na sua forma de ver a realidade. E se a pessoa que eu conheço aqui no Brasil, falando português, é o (a) mesmo (a) que eu conheceria no país de origem falando espanhol ou outra língua. E com esta pergunta eu pude perceber a visão que eles tinham de si mesmos com relação a como eles acreditam que são nos seus países e línguas maternas e como se viam aqui, na situação atual.

\section{Entrevista 1}

A primeira entrevista foi feita com uma aluna colombiana, de 25 anos, médica, que se formou na Colômbia. Sua mãe é policial e veio para o Brasil para trabalhar na embaixada da Colômbia em Brasília. Ela já tinha interesse de vir conhecer o Brasil e aproveitou esta oportunidade da mãe para concretizar seu desejo: "Eu antes de ser formada na minha profissão, eu queria viajar para o Brasil. Eu falava, 'Algum dia eu vou para o Brasil.'

Contudo, ela pensava que seria mais simples vir trabalhar e estudar aqui, que não precisaria falar bem português ou ter algum certificado da língua, mas acabou se deparando com alguns impedimentos, pois um dos requisitos era ter o Exame de Proficiência em Língua portuguesa do Brasil, o CELPE-Bras, requisito para poder estudar e fazer uma pós-graduação em dermatologia.

Ela disse: "Quando eu cheguei ao Brasil, eu comecei a procurar faculdades para estudar dermatologia, mas eu encontrei uma realidade diferente. Porque eu achava que eu chegava ao Brasil, com o pouco que sabia de português e ia começar. E não é assim não.”

Antes de vir morar com a mãe em Brasília, ela morou um mês em São Paulo e depois, quando chegou aqui, conheceu um colombiano que a ajudou a começar a trabalhar em um hospital público, como estagiária. Desta forma ela pôde conhecer mais da realidade brasileira.

Ela disse que: "Na verdade, eu achava que o Brasil era um país muito assim... rico, em dinheiro, assim, que não tinha pessoas pobres. "

Entretanto ela não viu isso de uma maneira ruim, mas sim percebeu que não havia tanta diferença entre os dois países, e que foi importante para ela, como pessoa, deparar- 
se com a realidade brasileira e ver esse lado sensível que, às vezes, acaba sendo deixado de lado pela profissão de médica.

Aqui tem pobreza, como nós temos lá, tem poucos médicos para a quantidade de pacientes, temos poucos recursos para trabalhar, igual ao meu país. Então, acho que a realidade do país é muito parecida com a realidade do meu país. E até acho que é um pouco mais complicado, porque vocês são muitas pessoas, o país é muito grande. Então, eu acho que para mim foi importante, sabe, ver pessoas pobres, com tantas necessidades. E foi legal, na verdade, porque conheci também minha parte sensible, que talvez... às vezes, como médico, eu esqueço, sabe?

Depois que ela veio para Brasília morar com a mãe, ela começou a frequentar um grupo de pessoas das diferentes embaixadas dos países da América Latina, e conheceu muita gente, com quem fez amizades e são pessoas que a ajudaram no seu desejo de passar no CELPE-Bras e cursar uma pós-graduação. Primeiro ela se dedicou e se esforçou muito para estudar e ser aprovada no exame de proficiência.

Na verdade, gosto muito do português. E eu fico à vontade. No começo eu ficava muito insegura, sabe? Mas, acho que já estou mais falando, gosto que me corrigem, sabe, quando eu falo errado, eu gosto. Sim, para melhorar. E, também, eu estou entendendo muito. No começo, quando meus amigos falavam piadas, eu nem entendia! Agora, eu já entendo já, pelo menos posso rir! Umas piadas, sabe? No começo, eu ficava assim, meio séria porque eu não sabia o que falavam. Eu acho que quando... chegamos a um lugar... é difícil, quando você não conhece ninguém, e você... sabe? Essas pessoas falam como gringos assim. Mas, depois, você se apodera dessa cultura, e tenta ser parte dela, você não vai perder as suas origens. Você vai continuar, mas pode ter a capacidade de se adaptar, de se acostumar e de viver melhor. Então, eu gosto.

$\mathrm{Eu}$, como professor dela nessa fase, vi a grande preocupação que ela tinha e o sentimento de desespero em pensar na hipótese de não ser aprovada no exame de proficiência, pois o tempo da sua mãe no Brasil já estava acabando e se ela não conseguisse uma aprovação iria acabar voltando para a Colômbia com a mãe. Assim, ela sempre me pedia muitos exercícios, lia muito, estudava muita gramática, só queria conversar com todos em português, na rua, na igreja, queria praticar o tempo todo. Realmente estava empenhada e focada nesta meta.

Assim, comecei a estudar muito, muito português. Com meu professor, e outras meninas, nós começamos a estudar muito com você. Estudar muito, muito. Às vezes eu até achava que não ia conseguir, sabe? Porque minha escrita era muito ruim. Eu acho que eu tentava falar, tinha muito sotaque, muito forte. Embora tenha, acho que melhorou muito. Então eu falava para você, "Ah, Daniel, coloque tarefa", e você me ajudava assim. Foi muito legal, sabe, por esse lado. Ah? Tá. Além disso, eu tentava também falar com brasileiros, para melhorar a pronúncia assim. Além do hospital, eu conheci outras pessoas. Eu sou católica, então elas me convidavam para ir à igreja. Assim, depois, eles faziam reuniões, faziam comida brasileira. Isso me ajudou também, sabe? 
Com relação às mudanças na sua personalidade, pude notar que com o passar dos meses ela foi mudando e se tornando mais aberta. No começo, eu a achava uma pessoa muito fechada, que não ria muito, não fazia muitos comentários, mas ao final do curso, ela já estava mais sorridente e falante. Interessante, pois pude perceber muito claramente essa diferença em mais ou menos três meses de curso. Isto me mostrou como as pessoas realmente mudam em uma nova sociedade, e como o meio em que estamos nos influencia e como influenciamos o meio, como não só as palavras, mas as atitudes, a forma como falamos e atuamos influenciam.

Eu acho também que algumas coisas da minha personalidade mudaram, sabe, quando eu cheguei aqui ao Brasil. Porque, eu sou uma pessoa muito séria. E, às vezes, até mal-humorada. Aqui, eu achei que os brasileiros são muito positivos, vocês têm uma atitude muito positiva ante as coisas da vida. E até percebi. Porque, vocês... eu não sei... porque vocês não falam "não" primeiro. E, o resto do Latino América fala "não", quando faz uma pergunta. Então, essa possibilidade de vocês me ajudou muito, para mudar muitas coisas da minha vida. Agora, eu tenho uma atitude diferente, eu sou mais alegre, acho que isso mudou. E mais tranquila, sabe? Eu me estressava muito, e eu acho que não é bom. Então... e também, vocês falam muito "Você vai conseguir." Então, essa palavra, eu já deixei na minha cabeça, para lembrar sempre que eu tenha um projeto, uma atividade, uma meta para o futuro. Eu gostei muito disso, sabe?

Ela conseguiu a aprovação no CELPE-Bras e foi para o Rio de Janeiro para tentar revalidar o seu diploma e poder trabalhar aqui no Brasil. Para disfrutar do tempo no país e não começar a estudar só depois de conseguir a revalidação, ela aproveitou para começar a estudar lá, pois em algumas universidades cariocas existe a possibilidade de fazer a pósgraduação como estrangeira, com exigência apenas do certificado de proficiência. Como o tempo de trabalho da sua mãe no Brasil acabou, ela foi morar na casa das filhas de um amigo brasileiro que fez aqui em Brasília, mas que moram no Rio de Janeiro. Atualmente ela já se sente mais à vontade falando português e gosta muito da língua.

Quando eu lhe perguntei sobre a diferença que tinha entre a pessoa que eu conheço aqui no Brasil falando português e a pessoa que eu conheceria antes, na Colômbia falando espanhol, ela me disse que realmente se vê de uma maneira distinta, pois é uma estrangeira aqui, então quando ela fala diferente, os outros a percebem como estrangeira, e a veem com outros olhos. Além disso, em espanhol ela fala de uma forma diferente, tanto sua dicção quanto sua velocidade. Então, além do sotaque, tem que mudar a forma como fala e a forma como age e lida com as pessoas. 
Porque aqui falo com um sotaque diferente. Até, quando eu comecei a falar, minha mãe olhava para mim como se eu fosse outra pessoa, sabe?! Eu falo espanhol rápido, às vezes enrolado, e também, na minha personalidade, é diferente. Assim, eu trabalhava como médica, e às vezes chegava a minha consulta, o estresse, os problemas... e até lidar com as pessoas. Na Colômbia, somos pessoas muito receptivas, mas às vezes somos muito fortes na forma de falar, entre nós. E acho que aqui no Brasil, vocês em geral são pessoas que recebem bem o estrangeiro, sabe? Pelo menos essa é a minha opinião. Então, quando eu chego brava, a um lugar aqui, já aconteceu. Um shopping, por exemplo, e eu pergunto para a moça, "Quanto vale isso?" E ela... a forma de... o jeito de falar, de me tratar é diferente, e eu mudo. Essa coragem que eu venho da rua, da minha casa, não sei, muda muita coisa. E, na Colômbia, por exemplo, eu chegava num lugar, no shopping, e às vezes a pessoa era até mais grossa do que eu. Então... então, lá, as pessoas são muito... somos muito... a palavra é tipo... prevenida, aqui não sei como fala. Isso, para mim, foi interessante. Além disso, também, agora, por exemplo, eu falo algumas palavras que eu não falava antes. Por exemplo, cumprimentar ao despedir, por exemplo, 'beijo,' 'abraço.' Porque, lá, não usamos, somos muito secos para falar assim, nós só falamos 'Ah, bueno, tchau.'ou 'Deus te abençoe', alguma coisa. Mas, aqui, são muito carinhosos até para se despedir, sabe? E isso são coisas que eu... he mudado, muito.

\section{Entrevista 2}

A segunda entrevista foi feita com uma aluna alemã, que aprendeu espanhol antes de português e está morando no Brasil há mais ou menos um ano. O caso dela é interessante, pois é economista, com doutorado e experiência na área, uma pessoa acostumada a sempre trabalhar. Entretanto o motivo de estar no Brasil é pelo trabalho do seu marido, o que fez com que ela tivesse que encarar uma realidade bem diferente da que estava acostumada, tornando-se dona-de-casa e tendo que cuidar dos filhos, sem trabalhar. Isso acabou sendo um ponto importante da entrevista, pois, com certeza, definiu muito a relação dela com a língua e os contextos de uso da língua.

\footnotetext{
Eu nasci na Alemanha, e sempre morei na Alemanha, até vinte e sete anos. Passei seis meses nos Estados Unidos quando eu tinha quinze anos. Nos mudamos várias vezes, na Alemanha, mas sempre na Alemanha. Sou economista, estou boring, aburrida, estudei economia em Berlim, meu doutorado em Berlim. Depois trabalhei como assistente na universidade, durante meu doutorado em Berlim. Depois eu fui à Namíbia, durante três anos trabalhei na Namíbia, para o Banco Central. E em Lesoto também, para o ministério de economia, fazenda... algo similar, em Lesoto. E, depois, fomos à Washington, e moramos lá oito anos, e eu trabalhei para o Banco Mundial, como economista.
}

Além do alemão, que é sua língua primeira, ela também fala inglês, francês e espanhol. Ela disse que seu francês é muito técnico da área de economia, ou seja, ela consegue usar termos muito específicos da economia, mas tem certa dificuldade para desenvolver conversas informais. Já com o espanhol ela está num processo de muita 
mistura com o português e acaba cometendo erros em espanhol, influenciados pelo português.

O francês, eu só aprendi para trabalho. Eu posso falar sobre orçamento, de dívida, tudo, tudo, tudo, mas não coisas normais, como... não sei... algo normal, eu não sei as palavras. Não consigo smalltalk. O espanhol, agora, eu não posso falar demais. Não, não... não. Eu tentei, e é um desastre.

\section{Com relação a sua vinda para o Brasil, ela explica a situação do trabalho do marido} e de como ela está um pouco entediada com a vida sem trabalho aqui.

Estamos aqui porque meu esposo está trabalhando aqui para o Fundo Monetário. E, para mim, é um câmbio... uma mudança bastante grande porque não só é outro país, outra língua, mas também, agora, eu não trabalho. Fico em casa, com as crianças, sim. Porque, morar em outro país não é diferente, mas eu me mudei muitas vezes, diferentes continentes e tudo. Adaptar... acostumar-se a outro país, eu sei como fazer normalmente, mas com trabalhar, quando tem uma identidade profissional. E, se você está na casa, com as crianças, não é... para as outras pessoas, não é importante seus estudos, se tem doutorado ou não. É só que você está com as crianças. Vida profissional, não existe. Isso é difícil.

Ela mostrou muita tristeza e até irritação com a desigualdade que percebe no

Brasil. Por eles morarem no Lago Sul e seus filhos estudarem em uma escola internacional, mostra-se mais latente a realidade dos ricos e como tratam os pobres. Ela inclusive compara com a África e comenta que nem lá chegou a ver tamanha desigualdade.

E eu não gosto porque acho que é muito estranha essa diferença entre ricos e pobres. E eu trabalhei muito em África, e outros países pobres, ou emergentes, mas nunca vi essa distância. Nunca. Acho que... falando com brasileiros, acho que Brasília é particular também, não? Que tem, especialmente em Lago Sul, essa escola, Escola Americana, também são pessoas que são... ricas, absurdo, não? Fim de semana, meu marido foi a um aniversário com Adrian, que tem cinco anos, né? Uma festa muito perto aqui, nesses condomínios de luxo, não? Festa enorme, muitas pessoas, e eles serviram Moët\&Chandon para os pais. Foi como quarenta, cinquenta garrafas de Moët\&Chandon. Nos Estados Unidos, é como oitenta dólares, não? E isso assim, pode ser que, também, é coisa da escola, que atrai mais os ricos, mas, em geral, as pessoas aqui, no Lago Sul, são muito esnobes, não? Muito... Para mim, eu tenho muita dificuldade de relacionar com eles. Eu não estou parte dos grupos deles, porque eles não me aceitam como pessoa que está... como elas. Eles... são as mães, normalmente. E eu... uma vez por semana, eu vou a uma escola em Águas Lindas, e a vida é totalmente diferente lá. Acho que, essa sociedade... também essa cultura aqui, que tem empregadas, que se trata como outra... outra classe... que despreza... como... não são pessoas, né? Não me gosta. E como eu detesto. Eu não quero que minhas crianças sabem como esses... Porque tem as crianças na escola, também, que têm babás, ou motoristas, que, para eles também, são só... Eles trabalham para a família, mas são pessoas também. E, com um salário de mil e quinhentos reais, não pode viver, não pode morar, né, num lugar como Brasília. Esse é um salário normal, para... Eu não sei... Também, as babás, em Washington, do Latino América, elas sempre disseram que não querem trabalhar para brasileiros, que os brasileiros são os piores dos... empleadores... empregadores. 
E sobre aquilo que ela gosta da vida aqui, ela fala bem da comida, do ensino no colégio dos filhos, da casa com bastante espaço e do trabalho do marido, que consegue ter tempo para a família.

Acho que toda... toda a família está muito feliz com a comida aqui! Meu filho, a comida preferida é arroz com feijão. Sim. Feijão preto, só. Feijão marrom, ele não gosta. Sim. E churrasco, e... E tem pessoas muito simpáticas, mas tem que encontrar, tem que achar. Mas tem festas boas, churrascos. E, também, com meu esposo, seu trabalho é bom, ele tem tempo para a família.

Além disso, destacou o aspecto estrutural e gramatical das línguas, além de mostrar grande interesse pelo português.

Depende da circunstância, assim, em geral, sim, mas tem pessoas assim, de outras partes do Brasil, que têm mais sotaque, que eu não posso compreender! Às vezes eu tenho mais problemas. Com telefone, às vezes... Telefone é mais difícil. Mas, em geral, assim... Não, eu... eu gosto muito da língua portuguesa, esta... é uma língua muito boa.

Acho que o espanhol é um pouco mais... não sei, lógico, para mim, às vezes. É mais... o português também. É mais fácil que francês. Mas é que tem muitas exceções.

Ao perguntar os contextos de uso da língua portuguesa, ela mostra que é na vida cotidiana o maior uso da língua, principalmente fora de casa.

$\mathrm{Na}$ escola, tenho que falar português com as professoras, com os outros pais, e com a empregada que temos. Quando vamos a essa escola em Águas Lindas, tenho que falar português com as crianças. E também com a vida normal, não? Tenho que ligar para marcar consultas, ou no supermercado e todas as situações que... Agora, como eu comecei com meu trabalho, também tenho que falar português com economistas aqui.

Ela também falou sobre a percepção que ela tem de si mesma, assim como as mudanças que tem percebido em sua identidade aqui no Brasil. Comenta ainda que se sente um pouco estúpida aos olhos dos outros por não sentir uma competência linguística total, e não conseguir falar tudo que ela gostaria de falar em português. Também se incomoda com a velocidade da fala e a forma como fala, o que faz com que ela até deixe de frequentar certos ambientes por não se sentir capaz de desenvolver a conversa da forma como gostaria ou ser vista como é vista em alemão ou em inglês.

Não é específico para português, se estou aprendendo uma língua e não completamente como avançado com a língua, sempre a identidade é diferente, porque as pessoas querem falar com você, e não podem. E te veem... veem você como um pouco mais estúpido, ou algo assim. É sempre assim. Porque... Mas, eles não falam... Aqui, uma coisa que eu não percebi antes é que não tem muitas pessoas que falam em inglês. Então, eu tenho que tentar falar português, e eles me veem como... Não, eles não me veem assim, como inteligente, não? E, para mim, é muito mais difícil de me expressar como quero. Em alemão, inglês, normalmente eu falo muito, faço muitos... como brigas, muitos jokes... Piadas, e com sarcasmo, e ironic, não? Ironia. E eu não posso, em português. Então isso, toda a minha pessoa é diferente, em português. Porque não posso expressar. Não 
falo muito, às vezes eu não quero ir a eventos porque eu sei que não posso participar, ou assistir como eu quero. Mas, toda língua... eu sempre falei muito, e rápido. Quando criança, minha amiga e eu tínhamos um clube de rápido falantes. Eu posso ler muito rápido, falar muito rápido, e... outra língua, eu não posso fazer isso como quero. Mas não é particular para português, mas para, sempre. Inglês não, inglês, eu posso fazer o mesmo que com o alemão. Mas, português, acho que essas nuances, não? De piada, algo... isso é muito difícil, não? De saber. E, se você não pode fazer isso, as outras pessoas têm você como outra pessoa.

\section{Entrevista 3}

A terceira pessoa entrevistada foi um amigo de El Salvador, que começou a aprender português lá no seu país de origem e veio para o Brasil há três anos, com o objetivo de se especializar na sua área, que é o ensino de português. Ele é apaixonado pelo português brasileiro e pelo Brasil, fato que dá certa peculiaridade à sua relação com a língua. Além disso, ele veio sozinho para o país com a intenção de estudar e permanecer aqui, mostrando sua relação não só com o Brasil, mas também com seu país de origem.

Ele conta que seu interesse pela língua surgiu quando ele era criança e seu pai assistia uma novela brasileira, mas não permitia que ele visse. Ele ficou interessado, por gostar da música e da sonoridade do português.

\footnotetext{
Bom, eu acho que isso começou quando eu tinha seis anos. Eu posso ir até lá para te contar que meu pai assistia uma novela chamada Pantanal, e... claro estava dublada na época, e eu achava curioso que ele estava grudado vendo a televisão. Eu me lembro, uma coisa que eu lembro assim, como se fosse ontem, é que eu queria ver televisão com ele. E ele não quis, ele falou: "Não, não, sai daqui, sai daqui." "Por que, pai?" "Não, é porque o programa não é para criança." Uma coisa que eu achava bastante bonita era a música da novela, que era em português. Achava muito bonito como que era o som da música, isso chamou minha atenção. Depois eu cresci, aí eu vi a novela, e aí vi porque meu pai não queria que eu ficasse com ele, né? Porque tinha mulher pelada. A Cristiane Oliveira, que ainda é muito bonita, ela estava pelada na novela, então meu pai estava apaixonado, eu acho. Então assim, depois eu cresci e vi um filme: Tieta do Agreste, não a novela. E aí, quando eu escutei as pessoas falando nesse sotaque bonito, nesse linguajar nordestino, eu achei muito bonito, eu não sei te explicar porquê. E eu prestei atenção nas vogais nasais, foi a única coisa que chamou minha atenção, e achei bonito, e ainda eu acho bonito, isso, no português brasileiro.
}

Apesar deste primeiro contato, ele só começou a estudar português muitos anos depois, já na faculdade. Ele conta que conheceu uma brasileira, que era professora de português, e foi quem acabou sendo sua primeira professora da língua.

Eu fui monitor dela e ela decidiu me levar para conhecer a embaixada, conhecer os professores. Me lembro que, nesse ano foi a Copa, na Alemanha. Aí, quando 
a gente estava entrando na embaixada, ela disse: "Eu te peço desculpa porque não vou falar mais espanhol. Eu vou falar português, porque minha mãe está aqui e, por um costume familiar, a gente fala português." Quando ela chegou e cumprimentou a mãe, as duas começaram a falar português, eu achei fantástico, pensei: 'Nossa, que coisa linda!' E aí, eu acho que fiquei mais apaixonado pela língua, por esse input, de estar escutando. E eu decidi que queria estudar, nesse momento.

Depois de um tempo estudando português, ele começou a conhecer brasileiros pela internet e tentou melhorar o português. Ele conta sobre dois amigos que fez, um com quem conversava de maneira mais informal e outro que era muito estrito e valorizava a variedade formal da língua.

Foi muito bacana porque, com um eu escrevia muitas coisas informais, como se eu estivesse falando com um amigo. E com o outro, como era clássico, cartesiano, ortodoxo, tradicional, purista, ele odiava português coloquial. Então, eu escrevia alguma coisa para ele, que eu tinha aprendido com o outro, ele corrigia. Ele falava: "Esse é linguajar de pessoas iletradas, então eu recomendo que você prefira esta estrutura." E ele escrevia.

E assim o gosto e o conhecimento pela língua portuguesa do Brasil foi aumentando e tomando conta da vida dele. Passado mais um tempo de estudos, ele já havia terminado sua graduação e a coordenadora do Centro Cultural de El Salvador lhe pediu para substituir uma professora, e foi quando ele lecionou pela primeira vez a língua portuguesa e decidiu que era o que ele queria para sua vida.

Ele falou sobre o porquê de ter vindo para o país:

Eu fiz uma substituição no Centro Cultural. Durante um mês... Eu não falava português, mas a diretora me chamou para dar aula, e eu achei o primeiro grande desafio da minha vida. Então, dei aula durante um mês. E essas coisas somente foram fortalecendo o vínculo que eu tenho com português. Então, depois desse mês... Eu amei a experiência, decidi que eu queria trabalhar com o ensino de português, e depois teve o concurso, graças a Deus eu passei, trabalhei lá durante três anos, e eu senti uma necessidade de ter uma formação na área. Então, foi por isso que, sem conhecer ninguém, sem saber o que eu ia fazer, eu pedi demissão do meu emprego, que eu trabalhava na embaixada do Brasil em El Salvador. Pedi demissão, falei para minha mãe: 'Eu não sei proncovô ((risos)), mas eu vou tentar fazer mestrado.' Aí, assim que eu vim para cá, por uma necessidade pessoal de ter uma formação na língua portuguesa.

Ele disse que, nesses três anos em que está vivendo no Brasil, muitas coisas aconteceram e mudaram sua vida, tanto profissional quanto pessoal. E ao perguntar sobre o desejo de continuar morando no Brasil ou voltar para seu país, ele expressou um gosto por seguir aqui, e que voltar para El Salvador seria, para ele, regredir.

Eu não sei se eu voltaria para El Salvador, o que eu sei é que eu quero trabalhar com português. Então... é uma parte que eu não consigo mais dissociar, isso está fora de cogitação. Pode ser em outro país, por que não? Pode ser na Argentina, pode ser no Uruguai, pode ser na Costa Rica. No meu país, eu não sei, porque... não sei, acho que não. Como é que eu posso te falar? Eu acho que eu me descobri muito no Brasil. Então, acho que, voltando ao meu país, seria como, não sei, 
regredir? Não sei. Acho que não. Mas, se eu pudesse, eu moraria no Brasil, com certeza.

Além da mudança que já ocorre normalmente nas vidas das pessoas quando se mudam para outro país, foi também a primeira vez que ele saia de casa para morar sem a mãe, o que fez com que ele amadurecesse bastante aqui no Brasil, e que tivesse que encarar várias situações boas e ruins. Com relação às suas percepções do país, ele disse que não imaginava que o Brasil fosse um país tão preconceituoso e homofóbico, pois vendemos uma imagem diferente para o exterior, como um país liberal e com uma mente aberta.

Eu nunca, nunca imaginei que no Brasil existisse homofobia e racismo, nunca. Nunca. Até porque vocês vendem uma imagem diferente, e, até, eu falava isso em sala de aula: 'O Brasil é um país muito aberto, de braços abertos, aceita tudo, tolera tudo', e não é. Ainda preconceituosos, homofóbicos, mas, todo o mundo é. Então... o meu país é muito mais. Então, é interessante... É, é difícil você entrar no Brasil e você ver isso, mas é normal, é o que acontece no mundo todo. Só que vocês vendem uma imagem diferente.

Quando lhe perguntei sobre seu gosto pela língua-cultura brasileira, ele mostrou mais uma vez essa paixão e como desfruta de cada palavra, de poder se comunicar, de se expressar e circular dentro da língua com liberdade, e como é prazeroso para ele.

\begin{abstract}
Eu não gosto, eu amo o português. Não é uma questão de gostar, acho que vai muito além. E, por exemplo, eu vou te contar poucas coisas porque, aí, eu não quero tirar teu tempo. Meu cartão foi clonado, semana retrasada. Aí, eu liguei, fiz o bloqueio, liguei, falei com dois atendentes, expliquei tudo. Claro, eu tava chateado. Mas, eu tava comentando com um amigo, e eu comecei a rir. E ele falou: "Você está rindo por quê?" Aí, eu falei para ele: "Porque eu fiz isso em português!" E ele: "O que que tem?" "Cara, é muito complicado você fazer noutra língua.” Então... Ou, por exemplo, eu tive um problema também, eu fui expulso do apartamento onde eu morava. Eu tava muito irritado, muito irritado, e eu comentei também para esse meu amigo o que aconteceu, e depois eu comecei a rir. E ele: "O que que está acontecendo com você rapaz?" Aí: "Rapaz, eu estou irritado, eu estou num nível muito alto de tensão, e eu consigo te contar em português." ((risos)) Claro, ele não dimensiona isso, porque ele não fala outra língua... eu falo um pouco de inglês também, espanhol e português. Então, eu sei o que é tentar explicar o mundo em outra língua. Então, é muito complicado, é complexo, é complexo demais. E, para mim, isso é delicioso, você poder fazer coisas que você naturalmente faria na sua língua mãe. Portanto você circula de uma forma tal, que também é permitido você fazer isso em outra língua. Isso é gostoso, rapaz.
\end{abstract}

Quando eu lhe perguntei sobre se sentir à vontade dentro da língua, e se havia algum tema que ele se sentisse mais livre em português do que em espanhol, ele me contou quão íntimo o português chegou na vida dele, e o nível de liberdade que ele passou a ter no Brasil, que ele não tinha em seu país.

O Brasil significa muito para mim, em termos de crescimento profissional, pessoal. E, principalmente, pessoal, de alguma forma. Por quê? Porque eu saí de casa, e eu vim ao Brasil sozinho. Então, eu tive que me virar muitas vezes. E eu acho que isso me deu certa emancipação, de alguma forma. E isso também foi 
até níveis íntimos, pessoais, de eu me aceitar totalmente como homossexual, e falar abertamente disso, eu comentar com as pessoas. E, do nada, eu, sem pensar, sem preparar nada, eu já chego falando que sou gay. Porque, para mim, não tem problema. E falar isso em português também é gostoso! Então, eu acho que eu me sinto mais livre em algumas coisas que eu, talvez, não falaria em espanhol. Falar, por exemplo, a minha preferência sexual, falar de coisas que eu quero, que eu não quero, e, sim, eu acho que eu faço isso mais em português, do que em espanhol. Curioso, eu não sei. Mas, é.

Já no fim da entrevista, ao questioná-lo sobre a percepção que ele tem de si mesmo aqui no Brasil falando português, e lá em El Salvador falando espanhol, ele falou que até sua mãe já havia comentado que ele havia mudado, e que ele, com toda a vivência aqui, com todas as experiências pessoais e profissionais dentro do contexto brasileiro, com certeza era outra pessoa, com relação àquela que saiu há três anos de El Salvador.

Você sabe que a última vez que eu fui, minha mãe falou para mim, "Você mudou." É. E eu acho que uma língua te faz isso, você vê a vida diferente. Porque você circula noutro ambiente, e você se adapta de uma forma tal, que você identifica aquele mundo como seu. Então, eu... eu não me acho brasileiro nem um pouco, eu sei que eu sou diferente, eu sei que eu sou estrangeiro. Mas, eu tento policiar minha pronúncia, para não ser apontado por aí, para não ser catalogado como o outro pelo meu jeito de falar. É por isso que eu tento me policiar com a pronúncia. Mas, eu não me sinto brasileiro, eu não... nem um pouco. Eu reivindico, muitas vezes, meu papel de estrangeiro, mas o português e o Brasil me mudaram de uma forma positiva, eu acho. Com certeza, a pessoa que estava lá, há três anos, em El Salvador era mais inibida, era mais calada, não falava o que sentia, e, agora, o português me deu isso, me deu essa chance de eu falar o que eu sinto, o que eu quero, o que eu penso e das coisas que eu gosto. Eu acho.

\section{Entrevista 4}

A quarta entrevista foi feita com um aluno chileno, que é engenheiro ambiental e professor universitário. Ele já morou em muitos países por causa dos seus estudos e trabalhos, dentre eles o Japão, onde conheceu sua esposa, que é brasileira. Eles vieram morar no Brasil por causa dela, o que fez com que ele tivesse que se adaptar ao mercado de trabalho e às oportunidades daqui.

Eu sou de nacionalidade chilena, minha graduação foi em Engenharia Ambiental, fiz parte dessa graduação nos Estados Unidos, onde morei um tempo. Ao terminar minha graduação, eu fiz meu mestrado na Suécia, mestrado em engenharia, e lá começou minha carreira de pesquisador. Durante esse período do mestrado, eu tive a oportunidade de participar de um grupo de pesquisa da Universidade de Tóquio, e aí fiz o doutorado lá, no futuro fui fazer minha tese de doutorado. No Japão, eu fiquei quatro anos e meio. Durante esse tempo, eu fui a um intercâmbio em duas universidades, que foi o Instituto Tecnológico de Massachusetts, em Boston, e a Universidade Tecnológica de Zurich. Depois que eu terminei o doutorado, foi no ano de dois mil e sete, eu decidi voltar para o Chile, eu dei aula por um semestre e foi a primeira vez que vine para o Brasil. Fiquei em São Paulo oito meses, trabalhando em consultoria. Mas, o meu início 
da relação com o Brasil, o motivo dela foi por minha futura esposa. Os pais dela moravam em São Paulo, então a gente decidiu ir para lá, eu me casei, né, nesse período, com ela, e poderia falar que esse foi o motivo principal, eu não tinha, eu não tinha muito conhecimento do Brasil, foi a primeira vez que fiquei lá, o mercado laboral não é fácil, que eu sou engenheiro, né? Bom, e fica limitado a fazer consultoria, ou acadêmico.

Ele falou que sua família ainda não sabe se vai ficar por muito tempo no Brasil ou não. Esse fato acaba gerando certa incerteza em sua vida, pois o que percebo é que ele não se entrega totalmente ao país, como se estivesse em sua casa, porque ainda existe certa expectativa de se mudar daqui. A esposa e ele tiveram um filho que nasceu no Brasil recentemente, e ele comenta que gostaria de voltar para o Chile e viver lá com sua família.

Na média, a gente fica de três a quatro anos no país, então não sei se em Brasília vai ficar muito tempo não, e depende das condições laborales, né? Eu queria ter a oportunidade de ir a morar no Chile, como família. Então, ainda tô vendo essa opção. Mas tudo vai depender do trabalho mesmo, né? Se vai ter algum trabalho ou não. Por agora a gente está estável, mas ninguém sabe.

Ele tem um forte relacionamento com o Japão e com a cultura japonesa. E além da questão familiar, de estar no Brasil principalmente por sua esposa, ele demonstra que, por haver uma grande colônia de japoneses aqui, ele se sente próximo ao Japão.

Ao falar sobre as diferenças que percebeu dentre os brasileiros, já que sua esposa é gaúcha, ele diz que pôde presenciar diferenças de costumes, e ele inclusive tem um pouco do sotaque do Rio Grande do Sul.

Eu acho que a parte interessante do país é a... o sentimento das pessoas, que é fácil comunicar-se com elas, né? É fácil realizar um tipo de amistad, né? Posso falar que mais próximo ao Latino América que o resto dos países que já morei. A comida também é similar. Assim, mas também tenía um outro aspecto que eu achei interessante, que, em meu caso, era um dos poucos países aqui no continente que tinha uma forte influência japonesa, que, no Chile, não tem. Então, foi como possibilidade de ficar mais perto do Japão, mas não indo morar no Japão, né, só foi um plus. Coisa ruim? Ah, bom, como todo país, tem seus aspectos errados, né? Como disse, acho que a violência, né, que o nível de crimes... criminosidade das pessoas é alto, da sociedade, né? Talvez seja porque o país é grande mesmo, né? $\mathrm{E}$ as ferramentas que as prefeituras têm não é suficiente. Mas é um tema mais político, né, como estrangeiro, é difícil avaliar isso. Interessante para mim foi ver essa diferença entre o Sul do Brasil e o Norte do Brasil, né? Em términos de infraestrutura, mas também entre a distribuição populacional, do tipo de pessoas também, né, do comportamento delas. Minha esposa é do Rio Grande do Sul, de Porto Alegre, então eu tive a oportunidade de viajar para lá, e acho que é outro Brasil, mesmo, comparado com Centro-Norte, ou Nordeste. Isso, eu acho que existe esse tipo de distinção. O meu país é diferente, né? O Chile é um país com governo centralizado, e aqui é estadual, né, então, cada qual tem sua identidade.

Quando questionado sobre a língua portuguesa, respondeu falando sobre a relação que tem com o português destacando as dificuldades como falante de espanhol, além da realidade que acontece com os hispanos, de pensarem que, por causa da proximidade e 
da fácil compreensão da língua em um primeiro momento, não precisam estudar muito. Entretanto acabam sem falar português realmente, vivendo em uma eterna tentativa de comunicação, mas sempre como estrangeiro e sem abrir mão da sua língua.

Bom, isso é... isso é mais... entra numa área mais cinza, né? Porque, quando eu conheci a minha esposa, foi em dois mil e três, eu já conhecia brasileiros, então, de certo modo, eu tentei comunicar-me com eles, então, desde dois mil e três, para aqui já estava tentando falar um tipo de português, né? Português errado, com certeza. Mas, aumentou o vocabulário, né, viendo tudo isso. Eu acho que isso ajudou, né? A grande diferença é que agora eu decidi pegar aulas, então estou vendo quales são as fundamentações que trate de tudo que eu falava, né, e quais são os aspectos errados. Então, eu acho que, nesse sentido, pegar aulas aqui na UnB foi positivo. Acontece bastante com hispano-falante, que acha que porque a língua é parecida, né, as palavras são parecidas, a pessoa não se dá o tempo de estudar mesmo, né? E aí cai nesse erro, né? Então, no final das contas, talvez um estrangeiro que não seja hispano-falante acaba falando melhor português que o hispano-falante, pela preguiça dele, de não fazer o esforço, né?

Além disso ele fala sobre como é em casa e as línguas que eles falam na comunicação diária, mostrando que o português aparece, mas não predomina na sua vida, pois ele realmente só precisa usar o português nas suas aulas na universidade.

Bom, em casa é mistura, né? Em casa fala mais uma mistura de japonês com inglês... e português, né? Porque, no fim das contas, tem muitas formas de expressar português, que eu fico mais à vontade em inglês, ou japonês. Então, aí, como que necessito ações mudam, né? Caso particular, como eu dou aula na UnB, tinha que melhorar minha base do português, né? Porque a maioria das aulas são em português, então aí tive um esforço a mais.

Ele conta que atualmente o português está influenciando seu espanhol, pois como ele não fala muito em espanhol, mas sim em inglês e japonês, agora ele está parecendo estrangeiro até mesmo no seu país de origem, e conta que chegou a passar por situações em que perguntaram se ele era estrangeiro no Chile.

O dia-a-dia... eu acho que é... que é misto, no sentido que é... talvez sem ter a intenção, eu misturo português com espanhol, quando estou intentando falar espanhol, né? Caso, foi agora, que fui de férias, para Chile, eu misturei, sendo que eu sou hispano-falante, né? Também, pode ser o caso que eu morei tanto tempo fora que é difícil, né? Somente falo espanhol quando tenho a oportunidade de fazer uma videoconferência com meus pais ou alguma das minhas irmãs, mas o resto é em inglês. Então, o uso da língua espanhola mesmo disminuiu bastante. Então, é raro, né? Em vez de misturar, quando eu estou falando português, com espanhol, faço do outro modo. Então, o pessoal lá agora ficava olhando quando eu falava qualquer coisa, né? Então. Teve um pessoal que já perguntou. Eu fui fazer uma papelada no ministério... havia uma moça do Chile, né, eu perguntei para ela, ela tem um filhinho, né? Qual que é o nome do filhinho. A gente ficou falando, e ela perguntou para mim se eu era estrangeiro. Aí eu fiquei sem jeito, né?

Quanto às mudanças que ele percebeu nele mesmo com relação a falar português

e sobre a língua-cultura brasileira, destaca que quando fala português tenta ser mais simpático, pois acredita que tanto em inglês quanto em espanhol ele é mais seco. 
Bom, a inserção de uma língua, a introdução da língua na pessoa sempre vai gerar um tipo de mudança, né? Mi caso, no meu caso, é uma mistura, né? Porque eu tive a oportunidade de morar em diferentes lugares, tem um tipo de... de influência, né? Talvez... penso que, quando eu falo português, eu tento ser mais simpático do que em espanhol e inglês. O inglês, eu sou mais seco, em espanhol também. Então... também tem que ver com o tipo de pessoas que eu falei em português. Bom, no ano anterior, nunca trabalhei ou nunca utilizei o português no trabalho mismo, então era o dia-a-dia que o tipo de conversa era diferente, né, também em casa. Mas, quando você trabalha, muda, né? Então, às vezes fico com a dúvida se está forte quando falo português, porque aí você não sabe se está falando muito forte ou não. Então, aí eu diminuo, principalmente com os estudantes.

Já com relação à cultura e à forma como as pessoas interagem, ele diz que sente o Brasil um país mais aberto, pois nos Estados Unidos e no Japão ele não poderia agir da mesma forma que aqui. Além disso, fala que no seu país, o Chile, por ele ter doutorado, parece sentir uma imposição de ter que se portar de uma determinada forma.

A cultura também, a cultura do país faz responder diferente, né? O Estados Unidos, lá é competitivo, personalista, então você tem que ser forte. No Japão tem a jerarquia. Então, você muda a forma de falar, de comportar-se. No Brasil é mais aberto. No Chile, eu acho que tem que ver também, a influência, também do que é o grau da pessoa, né? No sentido, o grau de profissão, né, algo é esperado que uma pessoa com doutorado e com anos de experiência tenha certo tipo de comportamento, né? Que não pode ser tão amistoso, ou aberto para hablar, né, que dá uma certa liberdade.

\section{Entrevista 5}

O quinto e último entrevistado foi um alemão com uma história muito peculiar com relação ao português e ao espanhol. Ele atualmente trabalha em um órgão internacional aqui no Brasil e deve permanecer por mais ou menos 4 anos no país. Sua história está repleta de conexões com o nosso país, pois passou alguns anos de sua infância aqui e foi alfabetizado em português, por causa do trabalho do seu pai.

É muito interessante, pois ele fala português praticamente sem nenhum sotaque estrangeiro, e passa tranquilamente por nativo da língua perante a sociedade. Entretanto, em algumas situações, por não ser brasileiro e por não perceberem que ele não é, acaba não entendendo certos comentários baseados em conhecimentos prévios óbvios para brasileiros, mas que passam despercebidos para estrangeiros que estão há pouco tempo no país, ou até para brasileiros que moram fora do país há muitos anos.

Ao contar um pouco sobre sua vida, ele diz:

Eu já passei várias vezes pelo Brasil, não é a primeira vez que estou aqui. Tudo começa em mil novecentos e setenta e oito, quando minha família, nós somos 
uma família de alemães, chegaram aqui pelo emprego do meu pai, meus pais, naquela época, não tinham nenhuma relação com o Brasil. Eu cheguei aqui ao Brasil aos três anos de idade e passei sete anos morando em Belo Horizonte. Uma família de alemães, mas eu acho que a minha socialização, a minha alfabetização, tudo isso aconteceu num contexto brasileiro. Naquela época, não tinha escola internacional, nada disso, então eu fui realmente socializado e alfabetizado no contexto brasileiro. Passei aqui uns sete anos morando, e aí a gente voltou para Alemanha. Depois passou um tempo na Alemanha, voltamos à América do Sul, mas, naquela época, pra Bolívia. E aí, eu terminei meus estudos da escola na Bolívia, voltei para a Alemanha e me formei de economista. Saindo da faculdade, eu comecei a trabalhar para uma instituição financeira internacional, de economista, e esse trabalho me levou de volta à região. Trabalhei sobre o Brasil, trabalhei sobre a Bolívia, outros países da América Latina. E, enfim, dois anos atrás surgiu a possibilidade de trabalhar aqui no Brasil, cheguei aqui um ano e meio atrás, e estou agora aqui, trabalhando como economista no país.

Apesar de ter um tempo determinado para viver no país, ele e sua família esforçam-se para entender e se adaptar ao que é local; ele afirma que estão muito satisfeitos e gostando bastante da cultura em geral: "Não estamos aqui para morar para sempre, eu acho que estamos vendo um período de três anos, quatro anos, que vamos morar aqui no Brasil.”.

O Brasil e a língua portuguesa acabaram mudando bastante sua visão como um alemão "tradicional", e ele mesmo percebeu isso quando veio morar no Brasil no ano passado com sua família e pôde perceber os estranhamentos que sua esposa e seus filhos tiveram, com relação a aspectos que ele já considerava como algo normal, por já estar acostumado à cultura local.

Voltando ao Brasil, depois de muitos anos, eu percebi que eu reconhecia muitos traços da sociedade, muitas características, então eu tive poucos momentos nos quais eu fiquei surpreendido. Tudo era, de uma certa forma, conhecido, mas isso foi... e, também, vendo minha família, que não é brasileira, se surpreendeu um pouco mais, houve situações nas quais eu entendia as pessoas, as formas de ser, a cultura, e eles não. E foi aí que eu percebi mais uma vez que eu, por ter passado a infância aqui no Brasil, eu tenho uma certa facilidade de entender.

Ele também explicita sua visão e seu ponto de vista sobre aspectos positivos e negativos do Brasil, explicando:

O que que eu gosto? Eu gosto da espontaneidade das pessoas, da alegria, são dois traços, acho muito importantes aqui no Brasil. O que eu não gosto? O Brasil é uma sociedade que ainda está em transformação, e uma parte dessa transformação acho que é a desigualdade. Eu acho que tem um grupo de pessoas que está tendo uma vida muito boa no Brasil, mas uma grande parte de pessoas que ainda está no processo de aumentar renda, e de aumentar as possibilidades de educação para as famílias, tem muitos problemas de saúde, do sistema de saúde. Então é essa percepção de divergência e de desigualdade que é um tema que eu vejo com uma certa preocupação, e que eu gostaria de ver mais progresso. 
Já sobre as línguas que fala no seu dia-a-dia, explica que no ambiente de trabalho fala principalmente português e em casa, alemão. Entretanto, se sente muito confortável falando português em situações cotidianas também.

A maior parte do meu dia eu falo português, eu falo por razões de trabalho. Eu trabalho muito com o Governo do Brasil, tanto no Banco Central como no Ministério da Fazenda, então aí, eu falo muito português. Também, aqui no escritório, meus colegas são brasileiros, então eu costumo falar português. Então, é mais no âmbito profissional, eu diria. Em casa, sendo uma família de alemães, eu só falo alemão. Às vezes, com meus filhos, agora, eu começo a falar português, porque eles chegam da escola e me contam piadas em português, me perguntam: 'Pai, o que que é isso? O que é, o que é?' Aí, a gente entra naquelas brincadeiras, e daí eu falo português com eles. Mas assim, conversas mais sérias na casa, com as crianças, com minha esposa é sempre em alemão. Eu diria que, com minha família, sempre será em alemão. Eu acho que, aí, o fato do alemão ser a nossa língua principal em casa, sempre me vai colocar nessa situação. Agora, falando com amigos, assim... eu não diria mais à vontade, mas eu diria que tem situações que tanto faz, para mim, falar português ou alemão.

Ao perguntar-lhe sobre as diferenças que ele percebe quando fala português ou alemão, afirma que percebe diferenças ao estar se expressando nas diferentes línguas e no comportamento que tem nos diferentes países.

Certamente, certamente. Eu acho que... Bom, eu mesmo percebo que eu me comporto de uma forma diferente, quando eu falo português ou alemão. Eu acho que eu sou mais expressivo, eu uso... a entonização da língua é diferente. Eu até acho que eu gesticulo mais quando eu falo português. Mas, também, alemão é uma língua muito... como eu diria? Muito clara. É difícil expressar uma situação na qual você não quer tomar uma posição firme, porque... eu acho que em português é mais fácil, em português você pode dar uma entonação de talvez isso, talvez aquilo, que dá um jeito que talvez é um pouco mais difícil ser expressado em alemão. Isso tem que ver com a língua, mas, claramente, também com a mentalidade das pessoas. E, nesse sentido, eu acho que ter aprendido o português de infância aqui no Brasil também influenciou minha percepção e minha identidade. Assim, comunicação é mais do que só falar uma língua, tem vários níveis dessa comunicação, e eu acho que para levar essa comunicação ao sucesso é importante fazer essas pontes além da própria língua. Eu acho que, nesse caso, eu tenho habilidade de conversar, de me comunicar com o brasileiro e me comunicar com o alemão.

Ao final da entrevista falamos um pouco em espanhol para que ele explicasse a diferença de como se sente falando português e espanhol. Apesar do domínio e de ter vivido vários anos na Bolívia, ele se sente mais à vontade em português, além de acreditar possuir uma identidade mais consistente na nossa língua.

Mira. Te cuento que, al hablar español, la variación de españoles que uno tiene en la América Latina, en la América central y en España es muy grande. Y en los últimos años yo viví con gente de España, yo trabajé mucho con gente de Latinoamérica, de diversos países, y una cosa que noté, que no tengo tanto en portugués, pero la veo en español, es que yo me acerco mucho al acento que tiene otra persona. Así, si me escuchas hablando con un argentino, después de un tiempo yo voy imitando al argentino, cuando paso dos días en Bolivia, ya voy a hablar como boliviano. Yo no sé por qué. No me gusta. Quisiera tener una versión propia de mi español, pero veo que me acerco a la forma como habla la otra persona habla español. Es muy raro ((risos)). Y la persona piensa que la 
estoy imitando, pues llega uno, empieza a hablar como boliviano y termina hablando como argentino. O sea, es algo que todavía estoy buscando tener un español propio mío, pero como la diferencia de españoles que encuentras en América Latina, entre chileno y argentino, boliviano y colombiano, ni hablando del mexicano, es tan grande, a veces me cuesta situarme y definir cuál es mi forma de hablar español.

\subsection{O DEPOIS}

Saussure enfatiza o caráter interacional e constitutivo da linguagem, ao afirmar ([1916] 2000): "não haveria possibilidade de língua se não houvesse a necessidade da fala; também não teríamos a linguagem se não fosse pelo outro que nos constitui e que nos ajuda a reconhecer quem somos". Ao longo da dissertação, apresentei e discuti o trabalho de outros teóricos e pesquisadores que referendam essa assunção, essencial à compreensão do terceiro capítulo desta dissertação. Retomemos, também, a afirmação de Ducrot, para quem a língua é fundamentalmente um lugar de debate e confrontação de subjetividades (1987, p. 30).

Como enfatizei nos capítulos anteriores e, ainda, como ficou nítido no presente capítulo a partir das noções de identidade e língua-cultura trazidas pelos participantes da pesquisa, a língua, fundada nas interações de sujeitos, de humanos, é fundante, também, desses sujeitos. Assim, em contexto estrangeiro, esse confronto de subjetividades não se dá unicamente entre o sujeito e as pessoas com quem se encontra e convive; mas, ainda e especialmente no que diz respeito à minha pesquisa, num confronto de sua própria subjetividade prévia, constituída desde seu contexto de origem, e a subjetividade em formação no Brasil.

Em alguns casos aqui apresentados, é explicitada a importância da língua para impulsionar transformações pessoais, subjetivas, por um lado, e coletivas, por outro, no sentido do estar no mundo e modificar também essa realidade a partir da língua; isso fica especialmente claro nos depoimentos da primeira e do terceiro entrevistados, que tinham grande interesse de vir para o Brasil e aprender o português brasileiro.

"Algum dia eu vou para o Brasil", essa primeira entrevistada afirmou. Com essa frase, podemos perceber e nos orgulhar da imagem que nosso país tem para a maioria dos estrangeiros. Com certeza existem problemas no Brasil, contudo, a curiosidade para 
conhecer as praias, as pessoas, as belezas naturais, supera até o medo da violência e da instabilidade trazida pelas crises que vivemos.

No caso do terceiro entrevistado, é ainda enfatizada a disparidade entre a imagem pública de um Brasil turístico, vendida internacionalmente, e a realidade difícil de ser vivida por alguns segmentos - enquanto ele relata a homofobia e o racismo, a segunda e o quinto entrevistado lamentam as desigualdades socioeconômicas que atingem a população pobre e impede acesso a direitos básicos, como a saúde.

É interessante perceber essa reconstrução da imagem que os entrevistados tinham do Brasil antes de virem para cá, uma vez que essa imagem mudou com o tempo aqui por causa da relação com a alteridade e com a mudança de suas próprias identidades. No capítulo dois vimos, com Suely Rolnik (1992) e Foucault (2010), os efeitos que a existência do outro tem sobre nós - existência essa que se conjuga à do eu para instituir a própria alteridade.

Esse conjunto de deslocamentos que significa o primeiro deslocamento, geográfico, e que é formado por outros, culturais, linguísticos, pessoais, profissionais etc., está relacionado a mais que uma alteração do olhar e/ou da imagem do país em que se chega, pois também se relaciona às alterações de olhares e imagens para o próprio país de origem, para o próprio contexto que era estável. É o que o quarto entrevistado nos permite entrever, uma vez que ele enfatiza o deslocamento linguístico e cultural experimentado no Chile, país de origem, depois de ter vivido no Japão, nos EUA, e agora no Brasil.

A primeira entrevistada também relata as diferentes condutas sociais de maior ou menor polidez, como é possível inferir por seu depoimento. A mudança para o Brasil lhe permitiu observar e classificar uma maior dureza no trato com outras pessoas como um traço típico da Colômbia, de onde veio. Considero seu depoimento importante ao dialogar com a noção, discutida no capítulo dois, de tradução - vista aqui em sentido lato como uma prática cultural-linguística de comunicação de palavras, sentidos, e das próprias expressões da subjetividade - como um exercício da alteridade que tem implicações no sujeito que a faz, e no contexto em que está inserido.

Para Revuz (2001, p. 229), esse exercício de alteridade é um exercício de estranhamento, e é parte intrínseca do aprendizado de outra língua, o qual depende da entrega a um duplo desconhecimento: "desconhecimento do Outro, da alteridade e desconhecimento de si e do próprio estranhamento". Isso posto é interessante perceber o 
êxtase relatado pelo terceiro entrevistado ao ver-se capaz de vivenciar e se expressar em português brasileiro durante interações negativas. A capacidade de passar por tais situações em pleno domínio do idioma o fez rir das próprias situações, sentindo-se satisfeito consigo mesmo.

Ainda com relação às percepções prévias à vinda para o Brasil (geralmente associadas a estereótipos e preocupações) e a percepção pós-vinda, em que pesam as preocupações e interesses dos seus cotidianos, importa ressaltar que essas mudanças nos pontos de vista são muito importantes para demonstrar como eles já se sentem mais à vontade no lugar que estão agora. Assim, ao destacarem pontos positivos ou negativos do Brasil, o fazem com uma visão menos estrangeira do país, mas sim uma visão preocupada, seja com a desigualdade, seja com a pobreza e com a violência. Mostram que já têm um sentimento pelo país, pela sua casa, pela língua, pela comida e pelas pessoas. Mostram que as diferenças, muitas vezes, não são tão grandes entres seus dois países, o Brasil e seu país natal.

Não só as palavras, não só o idioma em si, mas as atitudes de uma sociedade também mudam e influenciam a forma como falamos e nos portamos. Suponho que a entrevistada colombiana, que se dizia fechada e até mal-humorada, teve muitas mudanças em sua vida, e imagino se, quando voltar para a Colômbia, o contato com a língua-cultura brasileira terá influenciado a ponto de levá-la a despedir-se com beijos e abraços. Indago também se, depois do aprendizado e do empreendimento consciente em mudar a forma de tratamento com outras pessoas especialmente no contex to de sua própria docência, o entrevistado chileno que relatou ser mais simpático em português brasileiro do que ao falar espanhol e inglês vai, no Chile (onde pelo sotaque já foi perguntado se seria estrangeiro), ser mais simpático, consciente ou inconscientemente.

O interesse suscitado na escuta dessas autopercepções de mudanças íntimas de traços constitutivos de cada sujeito entrevistado vai ao encontro de uma pergunta inicial a essa pesquisa, tornando-se uma resposta positiva: há mudanças significativas na subjetividade e, portanto, na identidade desses sujeitos em tradução, relacionada ao aprendizado de uma nova língua, ao contexto estrangeiro que motiva tal aprendizado, e aos vários processos de tradução (subjetiva, linguística, cultural) vivenciados por eles.

Se, como afirmou Wanderley (1994), a tradução é um ser permanentemente em curso, então podemos concluir que estar em curso põe os sujeitos permanentemente em tradução. No depoimento da segunda entrevistada, essa noção está relacionada à limitação 
que ela percebe em sua própria performance social devida ao não-domínio da língua, por um lado, e, por outro, à mudança de status que enfrentou com a mudança, uma vez que vir para o Brasil acompanhar o marido implicou em abandono de sua carreira de economista.

Em seu relato, fica nítida a forma como ela imagina que os outros vão percebê-la, já visualizando, baseada em sua trajetória anterior, como os outros vão pensar que ela é devido ao momento em que está vivendo, o que demonstra seus receios e preocupações, como por exemplo ser vista como dona de casa, e não saberem que ela possui doutorado. Ela também relata grande incômodo por não poder fazer piadas e ironias da mesma forma que faz em sua língua primeira ou em inglês, ou não poder falar na mesma velocidade, e assim, parecer um pouco estúpida.

Entretanto, por outro lado, a língua pode também significar mudanças positivas e permitir um fortalecimento subjetivo. É o caso do entrevistado que se encontrou no Brasil, por se sentir mais livre e poder assumir sua homossexualidade sem se preocupar com a visão do outro ou com experiências passadas negativas.

Além de as pessoas mudarem em uma nova sociedade, o meio onde elas estão também muda e é influenciado por elas. Não tinha como estudar tão a fundo a alteridade e não ser tocado por ela, e com certeza eu fui tocado e mudado por essas pessoas na minha forma de pensar e ver a realidade que estou acostumado. Cada entrevista, cada resposta mexia comigo também, com meu orgulho inconsciente de brasileiro, de talvez não querer mudar o eu por causa de uma opinião do outro, de talvez não querer escutar algum deles falando mal do meu país, ou ter que escutá-los falando algo e não poder influenciar na resposta deles.

Por outro lado, um prazer de vê-los contentes no nosso solo e até emocionado por perceber o carinho e atenção com que se referiam ao país. Coisas que, por vezes, não percebemos na nossa língua-cultura ganham destaque aos olhos dos estrangeiros, tanto percepções meramente linguísticas, como as dúvidas entre português e espanhol e suas dificuldades, quanto percepções a nível cultural e pragmático. Com certeza é um aprendizado constante para ambos os lados, para eles um constante descobrimento e para nós uma constante percepção de nossas atitudes dentro e fora da língua.

Compreender a ambiguidade desse processo pode também nos permitir vivenciar os encontros entre línguas-culturas e sujeitos como algo corriqueiro na coexistência das línguas, e que propiciem encontros de transformações significativas para os sujeitos e 
línguas em contato e trânsito. O prefixo trans é explorado por Bernd (2005) como um propício a pensar a perspectiva transcultural e também a tradução (translation, em inglês, como a autora ressalta).

Ela parte de uma perspectiva dialógica entre as comunidades culturais, por acreditar que tal abordagem "[...] inaugura vias de reciprocidade nas relações culturais" (BERND, 2005, p. 149). Ao vermos as respostas, podemos perceber a influência que existe do contexto em que cada um se relaciona com a língua, o motivo de estar no Brasil, as atividades que costuma fazer aqui, a relação criada com brasileiros e as experiências positivas e negativas pelas quais passou. $\mathrm{E}$ ao percebermos toda essa gama de fatores externos a cada um, observamos como a língua é dinâmica e como a tradução sofre influência de diversos lados, sem deixar ninguém imune.

Nesse sentido, fica pautada aquela característica discutida, no capítulo dois, como uma fragilidade estruturante da identidade e mesmo da língua-cultura, por mais que este par seja de certa forma protegido e difundido como de lenta mutação em especial pelos sistemas de tradição logocêntrica. A fragilidade é, no entanto, frutífera, significa a possibilidade de mudança, e sinaliza que há uma fácil "contaminação" do eu pelo outro e vice-versa.

Por fim, proponho uma reflexão sobre uma passagem de Berman, que resume a forma de pensar a Tradução, a qual a presente pesquisa tentou demonstrar:

\footnotetext{
A tradutologia não ensina $a$ tradução, mas sim, desenvolve de maneira conceitual a experiência que a tradução é na sua essência plural. Neste sentido, ela não concerne somente aos tradutores, mas a todos os que estão no espaço da tradução. Isto é, todos nós, considerando que, da tradução, ninguém está livre. (BERMAN, 2013, p. 31).
}

Toda vez que nos debruçamos sobre a cultura do outro, suas diferenças e semelhanças, acabamos refletindo sobre nós mesmos e sobre a forma como nos colocamos em relação a este outro. Pensar no outro é um convite à reflexão sobre si mesmo. O estudo da alteridade e da identidade leva-nos a uma nova leitura e uma nova maneira de perceber vários conceitos com os quais estamos acostumados e, dessa forma, leva-nos a um questionamento das teorias e das ideologias dominantes.

É no contato com o diferente, com a alteridade mesclada de estranheza, "que se desapontam muitas expectativas" (GADAMER, 1999, p. 525). Isso faz da compreensão um processo produtivo de conhecimentos, de construção de significados. É somente ao buscar o diferente que passamos a encarar a nós mesmos sob perspectivas novas (GADAMER, 1999, p. 540). 
No caso desta tradução do sujeito, a qual pude me aprofundar durante esta pesquisa, o original e a tradução se confundem, pois aquele ser que existia antes já foi influenciado pelo ser atual. Assim, suas próprias percepções de um "eu" anterior estão marcadas ou filtradas por quem é no momento presente. Apesar de ele pensar que não consegue ser a mesma pessoa que era na língua primeira, agora imerso em língua estrangeira, o contrário tampouco é possível, visto que ele já foi tocado pela língua-cultura do outro país e não será quem ele era antes, inclusive no seu próprio país, pois foi influenciado pelo estrangeiro na sua forma de pensar anterior. Da mesma forma que qualquer tradução, escrita ou não, que também não é nem um texto na língua de origem nem um texto na língua de chegada, é uma mescla dessas duas línguas com as particularidades de um texto traduzido. 


\section{CONCLUSÃO}

Como nos propõe Antoine Berman (2013, p.27): “A ambição da tradutologia não deveria ser a de estruturar uma teoria geral da tradução, pois tal teoria não pode existir, pois o espaço da tradução é babélico, isto é, recusa qualquer totalização.”. E a partir do momento que pensamos a tradução pelo viés da alteridade e da identidade, damo-nos conta de que a relação existente nesse processo é individual e não há como generalizar de uma forma exata ou consciente.

Nesse sentido, qualquer análise que respeite esse ponto de partida há de se propor descritiva, ao invés de prescritiva. O que empreendi com esta pesquisa foi uma análise que, partindo da questão central, buscando ver a tradução sob um novo prisma, como encontro entre línguas, pudesse trazer novas possibilidades de caminhos e não respostas fechadas.

A presente pesquisa, sem pretender esgotar o assunto em questão, permitiu-me expandir diversos temas que considero importantes para a área dos Estudos da Tradução. Primeiramente, ao estudar a tradução não apenas como uma prática profissional, mas como uma prática discursiva e social, na formação da identidade do sujeito em contexto de imersão na língua-cultura brasileira, isto é, como um encontro entre línguas, pude perceber a abrangência da área e do termo Tradução.

A partir daí, pude me dar conta de que as línguas com as quais lidamos todos os dias são vivas, dependem de diversos fatores, como: a entonação do sujeito, o ritmo, as pausas, os silêncios, as formas como nos portamos, a nossa profissão, a família, os anseios, os meios onde vivemos, os fatores políticos, econômicos, culturais, as heranças que são passadas de geração a geração, entre outros. A língua é o uso que fazemos dela, e a tradução é a língua em uso. Por isso, quando faço parte de uma comunidade, os estranhamentos que no começo podem surgir vão sumindo com o passar do tempo - ou tornando-se outros. E isso provoca uma tradução de si mesmo, uma tradução do outro e do meio à nossa volta.

Desse modo, o resultado de um processo de tradução mostra uma mistura do conteúdo na língua de partida e dos vários discursos presentes nessa língua de partida, porém com relevância para o receptor dessa mensagem na língua de chegada, com seus discursos peculiares e interpretação da língua de chegada, destacando também as diferenças entre esses dois ou vários discursos. 
Nessa mesma linha de discussão, pude passar a pesquisar ao processo identitário, e perceber como ele é um processo de tradução constante, no qual estão em contato percepções, expectativas, condutas internas e externas, capazes de mostrar uma imagem da tradução como um desejo ou uma condição inata ao ser humano. A tradução é percebida então como um amplo processo cultural, linguístico e subjetivo de significação e ressignificação.

Além disso, temos que levar em consideração que quaisquer palavras que utilizamos para traduzir o outro estão restritas política-econômica-culturalmente, pois não existem palavras neutras para falarmos sobre o estranho. Isso se dá justamente por não sermos neutros, nem termos um olhar que seja desenraizado, pois são exatamente todos os nossos enraizamentos que constroem nossa relação com a alteridade.

Reaprender a olhar, ou, ainda, assumir essa não-neutralidade inerente à nossa condição de sujeitos contextualizados; é isso que Haraway propõe (1995) em sua metáfora de retomada da visão como sentido incorporado (ou seja, relacionado, necessariamente, a um corpo, a uma materialidade) para fundamentação de uma produção de saberes que prescinda o mito da objetividade (científica) e assuma a humanidade do processo.

Assim, reitero que esse debate ultrapassa os Estudos da Tradução, uma vez que está relacionado aos aprendizados que surgem do encontro com o outro. Tem a ver com a capacidade e o desejo de um de receber o outro em sua autenticidade, em sua diferença. Para os Estudos da Tradução em particular, e para a tradição da prática da tradução, tornase à reflexão, feita anteriormente, para pensarmos se para compreender o outro, para traduzi-lo, preciso submetê-lo e enquadrá-lo nos meus esquemas mentais de conhecimento, que compõem aquilo que conheço e, em alguma medida, permitem que eu possa reconhecer o que não conheço, tornando-o inteligível.

É um paradoxo fundamental da diferença, o fato de que seu reconhecimento demanda simultaneamente distanciamento e empatia, e a disposição de reconhecer na própria natureza o que é estranho (e que assim poderá ser reconhecido), e reconhecer no estranho o que tem alguma semelhança à natureza própria. Um exercício que, assim descrito, parece complicado e, de certa forma, impossibilitado, mas é uma prática cotidiana em qualquer contato humano.

E, dessa forma, deparamo-nos com a dialética da alteridade, que se faz, assim, num jogo entre semelhanças e dessemelhanças, no qual do equilíbrio entre ambas depende 
a possibilidade urgente de fuga dos dois paradigmas binários, excludentes e redutores que se tornam a domesticação e a estrangeirização. Ou como nos propõe Gadamer, precisamos de um horizonte cambiante, que se amplie e desloque rumo ao que é outro, não buscando apenas um acordo, mas talvez um conflito que nos enriqueça e nos mostre a importância da alteridade para a constituição do eu.

Uma abordagem crítica da alteridade nos mostra que por causa de imagens e vivências anteriores, criamos padrões pré-estabelecidos de aceitação ou rechaço do outro, pois cada um tem seu próprio repertório psicossocial, cultural que compõe aquilo que conforma sua alteridade como constituinte de sua subjetividade. Assim, cada pessoa acaba julgando de forma individual os outros ao seu redor, e aos que são estrangeiros a partir da sua forma peculiar de ver o mundo, independente da sua língua primeira ser o espanhol ou outra língua de raízes distantes do português.

Isso não seria um problema, em si, se não fosse a base de etnocentrismos, responsáveis na contemporaneidade por um número crescente de violações a direitos humanos de pessoas e povos imigrantes num mundo em que as fronteiras, contraditoriamente, tanto mais se dilatam quanto se recrudescem. Para o campo dos Estudos da Tradução, as metáforas de que as línguas (e, portanto, culturas) em contato passam por uma situação intrínseca de tensão, não são apenas metáforas, nem tampouco um debate acadêmico, mas em casos extremos têm significado morte, perseguição e outros fatos drásticos.

Assim, o encontro entre tradução, identidade e alteridade é extremamente profícuo e permite que muitos caminhos teóricos e práticos sejam ainda trilhados. Com essa pesquisa, exploro um desses caminhos, e forneço ainda uma alternativa de conexão entre os Estudos da Tradução e o ensino segunda língua/língua estrangeira a partir da perspectiva dos estudos da identidade e alteridade, os quais têm sido analisados de forma mais sistematizada pelo campo dos Estudos Culturais.

Essa interdisciplinaridade é bem-vinda aos Estudos da Tradução pois podemos pôr o foco no texto, nas línguas em contato, ou nos processos tradutórios e nos tradutores. Berman também explicita que tradução é experiência, das obras, das línguas, e do serdas-obras e do ser-das-línguas (2013). Assim, é uma experiência inequivocamente humana, e por isso mesmo plural. Aquele encontro de subjetividades em que identidade e alteridade, língua e discurso, se articulam de forma ambígua, complementar, conflitiva. Além de formar subjetividades individuais, os processos relacionados às línguas-culturas 
estão fundamentalmente relacionados à formação das nações, em um processo constante e retroalimentar.

Conforme tratado no segundo capítulo, a formação de uma cultura nacional cria, entre outros traços constitutivos, padrões de alfabetização, gera uma língua vernácula como meio dominante de comunicação, e contribui para a definição de uma cultura homogênea - e, muitas vezes, hegemônica. Uma cultura nacional é um discurso, ou seja, um modo de construir sentidos que influencia e organiza tanto nossas ações quanto as concepções que temos de nós mesmos.

Assim, para ilustrar a presente pesquisa, pude entrevistar e mostrar um pouco das influências desses discursos nacionais, os estereótipos que cria e dos quais dependem, e do processo complexo de constantes traduções realizadas por aprendizes de um novo idioma que, mais que dominar uma nova língua-cultura, estão aprendendo a ser novos sujeitos nela e que, para isso, precisam desvincular-se do entendimento apenas superficial da língua e passar a perceber os níveis profundos discutidos neste trabalho. Considero esse aprendizado sobre suas próprias subjetividades uma forma de expansão de suas fronteiras identitárias, assim como das fronteiras linguísticas que cada um traz como parte fundamental de sua herança cultural.

Como nos propõe Lúcia Gonçalves de Freitas (2008): quando os aprendizes de uma segunda língua falam, eles não estão apenas trocando informações, mas organizando e reorganizando constantemente seu autoconhecimento, suas noções sobre quem são e como se relacionam com e no mundo social, pois o sujeito põe-se no mundo a partir das relações que estabelece. E essas relações, numa realidade como a nossa, estão pautadas pela linguagem.

No caso dos sujeitos que colaboraram com a presente pesquisa, os quais estão aqui definidos como aprendizes, mas são também escritores e leitores do mundo e não só da palavra e estão também em trânsito por esse território vasto da América Latina, creio também ser possível, a partir dos processos tradutórios que o contexto de ensino e aprendizagem do português brasileiro como segunda língua favorece, que se localizem criticamente, realizando esse exercício no limiar entre identidade e alteridade para repensar-se no espaço cultural brasileiro, em interface com as heranças nacionais e/ou étnicas trazidas de seus contextos hispano-falantes.

Dessa forma, pude também estabelecer um paralelo entre seus processos de aprendizado e prática do português brasileiro e a atividade tradutória, a qual está 
constantemente nos revelando diferentes alteridades, mas, ainda assim, por vezes, queremos impor nossas formas de interpretar determinada situação dentro dos nossos parâmetros. Isso nos leva a agir, muitas vezes, sem pensar na relevância do que é diferente ao nosso (e que nos propusemos a traduzir) em termos de representar importância no conteúdo expressivo de determinado discurso ou sujeito estrangeiro - ou melhor, estrangeirizado por nós.

Por isso, a consciência da nossa limitação em relação a uma visão parcial do outro é essencial para os Estudos da Tradução, para que não tomemos o outro simplesmente pelo que vemos, escutamos ou lemos, mas sim possamos perceber nossa própria incompletude e parcialidade ao traduzir e julgar outra cultura, pois não temos acesso a uma visão completa e neutra nem do outro nem de nós mesmos. Assim tampouco somos completos e, como nossas línguas-culturas, estamos em constante formação: construção, desconstrução, reconstrução, significação, ressignificação. Somos todos, para nós mesmos e para o mundo, sujeitos em tradução. 


\section{REFERÊNCIAS}

ALMEIDA FILHO, José Carlos Paes. Uma metodologia específica para o ensino de línguas próximas? In: . (Org.). Português para estrangeiros interface com o espanhol. 2. ed. Campinas: Pontes, 1995. p. 9-21.

ANTUNES, Irandé. Aula de português: encontro \& interação. São Paulo: Parábola, 2003.

AUGÉ, Marc. O sentido dos outros: atualidade da antropologia. Vozes, Petrópolis, 1999.

BAKHTIN, Mikhail. Estética da criação verbal. 2. ed. Trad. Maria Ermantina Galvão. São Paulo: Martins Fontes, 1997.

BASTOS, Liliana Cabral. Estórias, vida cotidiana e identidade - uma introdução ao estudo da narrativa. In: CALDAS-COULTHARD, Carmen Rosa; SCLIAR-CABRAL, Leonor (Org.). Desvendando discursos: conceitos básicos. Florianópolis: Editora da UFSC, 2008. p. 79-111.

BERMAN, Antoine. A tradução e a letra ou o albergue do longínquo. Trad. MarieHelene C. Torres, Mauri Furlan, Andreia Guerini. 2. ed. Florianópolis: Copiart PGET/UFSC, 2013.

. A prova do estrangeiro: cultura e tradução na Alemanha romântica. Trad. Maria Emília Pereira Chanut. Baurú: EDUSC, 2002.

BERMANN, Sandra. Introduction. In: , WOOD, Michael. Nation, language, and the ethics of translation. New Jersey: Princeton University Press, 2005. p. 1-10.

BLECUA, José Manuel. Linguística e significação. Rio de Janeiro: Salvat, 1979.

BRISSET, Annie. A tradução: modelo de hibridização das culturas? Interfaces Brasil/Canadá, n. 6, p. 175-197. Disponível em: <http://www.revistas.unilasalle.edu.br/index.php/interfaces/article/view/750/578>. Acesso em: 29 out. 2015.

BROWN, H. Douglas. Principles of language learning and teaching. 3. ed. Englewood Cliffs: Prentice Hall Regent, 1994.

CALDAS-COULTHARD, Carmen Rosa. Da análise do discurso à análise crítica do discurso: introduzindo conceitos. In: .; SCLIAR-CABRAL, Leonor (Org.). Desvendando discursos: conceitos básicos. Florianópolis: Editora da UFSC, 2008. p. 1944.

CALVO CAPILlA, Maria Carolina; RIDD, Mark. A tradução como atividade contrastiva e de conscientização na aprendizagem de línguas próximas. Horizontes de Linguística Aplicada, v. 8, n. 2, p. 150-165, 2009.

CAVALLARI, Juliana Santana. O conflitante encontro da língua maternal com uma língua estrangeira [document eletrônico]. 2009. Disponível em: <http://www.unicamp.br/iel/site/alunos/publicacoes/textos/c00015.htm>. Acesso em: 08 jun. 2015.

CHAMBERLAIN, Lori. Gênero e a metafórica da tradução. Tradução de Norma Viscardi. In: OTTONI, Paulo (Org.). Tradução: a prática da diferença. 2. ed. Campinas: Editora da Unicamp, 2005. p. 37-58. 
COSTA VAL, M.G. Redação e textualidade. São Paulo, Martins Fontes, 1991.

CRONIN, Michael. A era da tradução: tecnologia, tradução e diferença. Tradução de Roberto Schramm Júnior. In: BLUME, Rosvitha Friesen; PETERLE, Patricia (Org.). Tradução e relações de poder. Florianópolis: PGET - UFSC / Copiart, 2013. p. 193-222.

DELL'ISOLA, Regina Lúcia Péret. Aula de português: parâmetros e perspectivas. Belo Horizonte: FALE/UFMG, 2013. (Coleção Proleitura, v. 6)

DERRIDA, Jaques. Posições. Trad. Tomaz Tadeu da Silva. Belo Horizonte: Autêntica, 2001.

D'HULST, Lieven; VANDEMEULEBROUCKE, Karen. Entre belgas, ou como gerir a língua do outro no século XIX. Tradução de Luciana Wrege Rassier. In: BLUME, Rosvitha Friesen; PETERLE, Patricia (Org.). Tradução e relações de poder. Florianópolis: PGET - UFSC / Copiart, 2013. p. 287-308.

DUCROT, Oswald. O dizer e o dito. Campinas, SP: Pontes, 1987.

Prefácio. In: VOGT, Carlos. O intervalo semântico: Contribuição para uma teoria semântica argumentativa. Campinas: Editora Unicamp, 2009.

DUSCHATZKY, Silvia; SKLIAR, Carlos. O nome dos outros. Narrando a alteridade na cultura e na educação. In: LARROSA, Jorge; SKLIAR, Carlos (Org.) Habitantes de Babel: políticas e poéticas da diferença. Belo Horizonte: Autêntica, 2001.

ELLIS, R. Second language acquisition. Oxford: Oxford University Press, 1997.

FERREIRA Itacira Araújo. Português/ Espanhol: fronteiras linguísticas que devem ser delimitadas. In: ALMEIDA FILHO, José Carlos Paes (Org.). Português para estrangeiros interface com o espanhol. 2. ed. Campinas: Pontes, 2001. p. 141-156.

O ensino aprendizagem de Português/língua estrangeira no contexto do Mercosul In: ALMEIDA FILHO, José Carlos Paes (Org.). Português para estrangeiros interface com o espanhol. 2. ed. Campinas: Pontes, 2001. p. 39-47.

FLOTOW, Luise von. Traduzindo mulheres: de histórias e re-traduções recentes à tradução ,queerizante ee e outros desenvolvimentos significativos. Trad. de Tatiana Nascimento dos Santos. In: BLUME, Rosvitha Friesen; PETERLE, Patricia (Org.). Tradução e relações de poder. Florianópolis: PGET - UFSC / Copiart, 2013. p. 169192.

FREIRE, Paulo. A importância do ato de ler: em três artigos que se complementam. São Paulo: Autores Associados: Cortez, 1989. (Coleção Polêmicas do nosso tempo; 4)

FREITAS Lúcia Gonçalves. Identidade e Aquisição de Segunda Língua. In: MELLO, Heloísa Augusta Brito; FERREIRA, Maria Cristina Dalacorte. (Org.). Múltiplas vozes: estudos interculturais, estudos de bilinguismo e estudos da sala de aula de língua estrangeira. Goiânia: Ed. UFG, 2008. p. 220-233.

GADAMER, Hans-Georg. Verdade e método: traços fundamentais de uma hermenêutica filosófica. 3. ed. Trad. Flávio Paulo Meurer. Petrópolis: Vozes, 1999.

GALISSON, Robert. Quand la didactologie/didactique des langues étrangères redécouvre les cultures. In: GALISSON, Robert. De la langue à l aculture par les mots. Paris: CLE International, 1991.

GERHARDT, Tatiana Engel; SILVEIRA, Denise Tolfo (Org.). Métodos de pesquisa. Porto Alegre: Editora da UFRGS, 2009. 
GIL, Antonio Carlos. Como elaborar projetos de pesquisa. 4. ed. São Paulo: Atlas, 2002. Métodos e técnicas de pesquisa social. 6. ed. São Paulo: Atlas, 2008.

GNERRE, Maurizio. Linguagem, escrita e poder. 2. ed. São Paulo: Atlas, 1991.

GODARD, Barbara. Theorizing Feminist Discourse/Translation. Tessera, v. 6 (La traduction au feminine / Translating women), p. 4253, Spring / Printemps, 1989. Disponível em: <http://pi.library.yorku.ca/ojs/index.php/tessera/article/viewFile/23583/21 792>. Acesso em: 29 out. 2015.

. Relational logics: of linguistic and other transactions in the Americas. In: ALMEIDA, Sandra Regina Goulart (Org.). Perspectivas transnacionais: perspectives transnationales $=$ transnational perspectives. Belo Horizonte: ABECAN, FALE/UFMG, 2005. p. 241-273.

HALL, Stuart. A identidade cultural na pós-modernidade. 11. ed. Trad. Tomaz Tadeu da Silva e Guacira Lopes Louro. Rio de Janeiro: DP\&A, 2006.

HARAWAY, Donna. Saberes localizados: a questão da ciência para o feminismo e o privilégio da perspectiva parcial. Tradução de Mariza Corrêa. Pagu, Campinas, v. 5, p. 07-41, 1995. Disponível em: < http://www.clam.org.br/bibliotecadigital/uploads/publicacoes/1065_926_hARAWAY.p df>. Acesso em: 29 out 2015.

HOOKS, Bell. Linguagem: ensinar novas paisagens/novas linguagens. Trad. Carlianne Paiva Gonçalves, Joana Plaza Pinto, Paula de Almeida Silva. Estudos Feministas, Florianópolis, v. 16, n. 3, p. 857-864, jan. 2008. Disponível em: $<$ https://periodicos.ufsc.br/index.php/ref/article/view/S0104026X2008000300007/9136>. Acesso em: 29 out. 2015.

ITO, Gloria. El papel de la cultura dentro del aprendizaje de uma lengua extranjera. Revista Estudios de Linguística Aplicada, n. 14, p. 65-69, 1991.

JAKOBSON Roman. Lingüística e comunicação. Trad. Izidoro Blikstein; João Paulo Paes. São Paulo: Cultrix, 1975.

KRAMSCH, Claire. The cultural discourse of foreign language textbooks. In: SINGERMAN, A. (Ed.). Toward a new integration os language and culture. Middlebury, VT: Northeast Conference on the Teaching of Foreign Languages, 1996. p. 63-88.

Language and culture. Oxford: OUP, 1998.

KRASHEN, S.D. Principles and practice in second language acquisition. Oxford: Pergamon Press, 1982.

LARAIA, Roque de Barros. Cultura: um conceito antropológico. 18. ed. Rio de Janeiro: Jorge Zahar, 2005.

LORDE, Audre. Self definition and my poetry. In: BYRD, Rudolph; COLE, Johnnetta; Betsch; GUY-SHEFTALL, Beverly (Ed.). I am your sister: collected and unpublished writings of Oxford: Oxford University Press, 2009. p. 156-157.

LÖRSCHER, Wolfgang. Process oriented research into translation and implications for translations teaching. Ilha do Desterro, v. 44, p. 083-099, jan./ jun. 2003. Disponível em: $<$ https://periodicos.ufsc.br/index.php/desterro/article/viewFile/2175-

8026.2003n44p83/7020>. Acesso em: 09 jun. 2015. 
MANZINI, E. J. A entrevista na pesquisa social. Didática, São Paulo, v. 26/27, p. 149-158,1990/1991.

MARCUSCHI, Luiz Antônio. Compreensão textual como trabalho criativo. In: Universidade Estadual Paulista. Caderno de formação: formação de professores bloco 02: didática dos conteúdos. São Paulo: Cultura Acadêmica, 2011. p. 89-103. Disponível em:

<http://www.acervodigital.unesp.br/bitstream/123456789/40365/6/Caderno_bloco_2_v 3.pdf>. Acesso em: 29 out. 2015.

MASSEY, Gary. Process-oriented translator training and the challenge for e-learning.

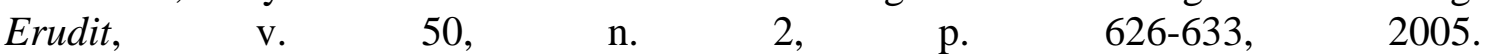
Disponível em: <https://www.erudit.org/revue/meta/2005/v50/n2/011006ar.pdf>. Acesso em: 09 jun. 2015.

MEDEIROS, João Bosco. Redação Científica. 11. Ed. São Paulo: Atlas, 2011.

MINAYO, Maria Cecília de Souza (Org.). Pesquisa social: teoria, método e criatividade. 28. ed. Petrópolis: Vozes, 2009.

MOITA LOPES, L.P. Discursos de identidade. Campinas: Mercado das Letras, 2003.

OLIVEIRA, Vera Lúcia de. O eu e o outro na tradução: pensando a alteridade. IpotesI, Juiz de Fora, v. 13, n. 1, p. 81 - 86, jan./jul. 2009. Disponível em: <http://www.ufjf.br/revistaipotesi/files/2011/04/9-O-eu-e-o-outro-na-traduçãopensando-a-alteridade.pdf $>$. Acesso em: 08 jun. 2015.

OLLER, John.; ZIAHOSSEINY, Seid. The contrastive analysis hypothesis and spelling errors. Language Learning, v. 20, 1970.

OTTONI, Paulo. Introdução: a prática da diferença. In: (Org.). Tradução: a prática da diferença. 2. ed. Campinas: Editora da Unicamp, 2005. p. 11-19.

PAZ, Octavio. Traducción: Literatura y literalidad. Tusquets Editores, 1971.

. Televisión: cultura y diversidad. Hombres en su siglo y otros ensayos. Barcelona: Biblioteca de Bolsillo, 1990.

PIMENTA, Selma G. Formação de professores: identidade e saberes da docência. In: (Org.). Saberes pedagógicos e atividade docente. São Paulo: Cortez, 2005.

RAJAGOPALAN, Kanavillil. O conceito de identidade em linguística: é chegada a hora de uma reconsideração radical? In: SIGNORINI, Inês. (Org.). Língua(gem) e identidade. Campinas: Mercado das letras, 1998. p. 21-46.

REVUZ, Christine. língua estrangeira entre o desejo de um outro lugar e o risco do exílio. In: SIGNORINI, Inês. (Org.). Língua(gem) e Identidade: elementos de uma discussão no campo aplicado. 2. ed. Campinas: Mercado das Letras; São Paulo: Fapesp, 2001. p. 213230.

RICOEUR, Paul. Sobre a tradução. Trad. Patrícia Lavelle. Belo Horizonte: Editora da UFMG, 2011.

RODRIGUES, Cristina C. Tradução e diferença. São Paulo: Editora Unesp, 1999.

ROLNIK, Suely. À sombra da cidadania: alteridade, homem da ética e reinvenção da democracia $\quad$ [on-line]. $1992 . \quad$ Disponível em: 
<http://www.pucsp.br/nucleodesubjetividade/Textos/SUELY/alteridadewalter.pdf>. Acesso em: 29 out. 2015.

RUIZ, Castor Bartolomé. Os paradoxos do imaginário. São Leopoldo, RS: Unisinos, 2003.

SAUSSURE, Ferdinand de. Curso de Linguística Geral. Org. Charles Bally e Albert Secheaye. São Paulo: Cultrix, 2000.

SILVA, Edna Lúcia da; MENEZES, Estera Muszkat. Metodologia da pesquisa e elaboração de dissertação. 4. ed. Florianópolis: UFSC, 2005.

SILVA, Gisele Dionísio. O Eu, o Outro e o Entrelugar: captando a interculturalidade na tradução. In: MELLO, Heloísa Augusta Brito; FERREIRA, Maria. Cristina. Dalacorte. (Org.). Múltiplas vozes: estudos interculturais, estudos de bilinguismo e estudos da sala de aula de língua estrangeira. Goiânia: Ed. UFG, 2008. p. 50-71.

TYMOCZKO, Maria. Ideologia e a posição do tradutor: em que sentido o tradutor se situa no "entre"(lugar)? Tradução de Ana Carla Teles. In: BLUME, Rosvitha Friesen; PETERLE, Patricia (Org.). Tradução e relações de poder. Florianópolis: PGET - UFSC / Copiart, 2013. p. 115-148.

ULSH, Jack.Lee. (Org.) From Spanish to Portuguese. Washington, D.C: Foreign Service Institute, 1971.

URGESE, Tania. Translation: how, when, and why. English Teaching Forum, p. 38-40, jul. 1989.

VENUTI, Lawrence. Escândalos da tradução: por uma ética da diferença. Tradução de Laureano Pelegrini, Lucinéia Marcelino Villela, Marileide Dias Esqueda e Valéria Biondo. Bauru (SP): EDUSC, 2002.

VERMER, Hans J. Skopos and Commission in Translational Action. In: CHESTERMAN, Andrew (Ed.). Readings in Translation Theory. Helsinki: Oy Finn Lectura Ab, 1989. pp. 173-87.

WANDERLEY, Jorge. Introdução. In: Shakespeare, William. Sonetos. Tradução: Jorge Wanderley. 2. ed. Rio de Janeiro: Civilização Brasileira. p. 9-23.

WIDDOWSON, Henry. Exploration in applied linguistic. Oxford: Oxford University Press, 1979.

ZOZZOLI, Rita Maria Diniz. Produção e autonomia relativa na aprendizagem de línguas. In: LEFFA, Vilson J. (Org.). Pesquisa em linguística aplicada: temas e métodos. Pelotas: Educat, 2006. p. 99-138.

ZURRITA NAVARETTE, P. La traducción explicativa y la traducción interiorizada en el proceso de enseñanza y el aprendizaje de una lengua extranjera. In: FELIX FERNANDEZ, Luis.; ORTEGA ARJONILLA, Emilio.(Ed.). Estudios de traducción y interpretación. Málaga: CEDMA, 1997. p. 133-139. 


\section{ANEXO A - TRANSCRIÇÕES DAS ENTREVISTAS}

Legenda:

... - pausa;

D - entrevistador;

R - entrevistado;

\section{ENTREVISTA 1}

D - Bom, então, primeiro eu queria que você falasse um pouco sobre o seu percurso até chegar ao Brasil. Falar quem é você, a sua profissão, o que você estudou, os países pelos quais você passou, as línguas que você fala, o porquê de ter vindo aqui para o Brasil, como que era sua vida antes e como é a sua vida aqui, agora.

[00:00:31] R - Bom, sou colombiana, tenho vinte e cinco anos... eu sou médica, fui formada na Colômbia, em uma linda cidade que se chama Cartagena. Eu trabalhei dois anos em Medelim, depois que me formei, e um dia, graças a deus, minha mãe ligou para mim, falando que chamaram ela para vir para o Brasil para trabalhar na embaixada da Colômbia. Então, eu vi isso como uma possibilidade para mim porque, eu antes de ser formada na minha profissão, eu queria viajar para o Brasil. Eu falava, "Algum dia eu vou para o Brasil." E, de fato, quando eu estava estudando na faculdade, eu comecei a estudar português. Assim, eu estudei de uma forma um pouco relaxada, um pouco assim. Porque eu achava que a Medicina era o mais importante. Então, eu dedicava pouco tempo para o português, na verdade. Mas, eu falava assim para o meu namorado, "Algum dia vou ter que viajar para o Brasil." Depois, como eu estava falando, minha mãe falou para vir para o Brasil, eu achei que era o melhor da vida. Então ali comecei a estudar mais assim, muito dedicada ao português, durante três meses, antes de vir para o Brasil. Eu estudei com professor particular, mas foi muito básico, foi um português muito básico. Além disso, eu trabalhava muito, então estava tendo dificuldades. Mas... eu chegava cansada e não chegava a estudar português. [00:02:44] Depois, quando cheguei ao Brasil, eu queria fazer... Eu quero fazer meu pós-graduação em dermatologia. Então, quando eu cheguei ao Brasil, eu comecei a procurar faculdades para estudar dermatologia. Mas, eu encontrei uma realidade diferente. Porque, eu achava que eu chegava ao Brasil, com o pouco que sabia de português e ia começar. E não é assim não. Eu precisava ter uns requisitos para... 
uns requerimentos? Requisitos? Para começar a faculdade. E um desses requisitos era ter o CELPE-Bras, que é o exame de proficiência. [00:03:28] E muitas faculdades fecharam as portas para eu me apresentar. Então, eu tive que esperar muito tempo, até chegar o momento do CELPE. Aí, comecei a conhecer a cultura do Brasil. Eu morei um mês em São Paulo, com uma brasileira, e depois eu vim para Brasília, para morar com a minha mãe. Então, eu cheguei lá, ela tem outra cultura, outros costumes, diferentes, e eu aprendi muita coisa, experimentei as comidas, [00:04:03] foi legal, assim. E, às vezes, ela ficava falando para mim, "E por que você não se preparou antes de venir para o Brasil? Por que você não fez o CELPE?" Na verdade, eu cheguei muito pouco... muito pouco informada... pouco informada. Então, eu falei, "Não, eu vou morar com minha mãe, acho que não vou ter dificuldade." Depois, eu vim para Brasília, conheci um colombiano. Ele me ajudou muito porque, ele me convidou para hospital público. E, lá, eu tive também a oportunidade de melhorar o meu português, me ajudou muito a falar com as pessoas, a praticar, tudo isso. E a conhecer a realidade do Brasil. Porque, na verdade, eu achava que o Brasil era um país muito assim... rico, em dinheiro, assim, que não tinha pessoas pobres. [00:05:06] Assim, as pessoas têm uma imagem diferente, sabe? desde outro lugar. E yo vi que aqui também tem iguais problemas do que meu país. Aqui tem pobreza, como nós temos lá, tem poucos médicos para a quantidade de pacientes, temos poucos recursos para trabalhar, igual ao meu país. Então, acho que a realidade do país é muito parecida com a realidade do meu país. E até acho que é um pouco mais complicado, porque vocês são muitas pessoas, o país é muito grande. Então, eu acho que para mim foi importante, sabe?, ver pessoas pobres, com tantas necessidades. E foi legal, na verdade, porque conheci também minha parte sensible, que talvez... às vezes, como médico, eu esqueço, sabe? Bom, depois... eu comecei a assistir a um lugar... a ir a um lugar onde se reúnem as pessoas... estrangeiros, pessoas de diferentes países... Peru, Chile, Latino América, Brasil... nas sextas-feiras. Então, eu fui lá com minha família, conheci muitas pessoas. As pessoas... interagimos, falamos espanhol ou português, a maioria espanhol, a maior parte do tempo. E lá conheci uma peruana, que se chama Juliete, ela me... eu falei que eu queria fazer o CELPE porque é um requisito, ter... era um requisito ter um nível intermediário ou superior, então eu precisava. Assim, eu estava assustada, eu precisava passar num primeiro momento. Então, ela falou que ela conhecia um professor muito bom, muito legal, e ela me apresentou com você. [00:07:23] E aí eu liguei, nós falamos e me preparei. Assim, comecei a estudar muito, muito português. Com meu professor, e outras meninas, 
nós começamos a estudar muito com você. Estudar muito, muito. Às vezes eu até achava que não ia conseguir, sabe? Porque minha escrita era muito ruim. Eu acho que eu tentava falar, tinha muito sotaque, muito forte. Embora tenho, acho que melhorou muito. Então eu falava para você, [00:08:04] "Ah, Daniel, coloque tarefa", e você me ajudava assim. Foi muito legal, sabe? por esse lado. Ah? Tá. Além disso, eu tentava também falar com brasileiros, para melhorar a pronúncia assim. Além do hospital, eu conheci outras pessoas. Eu sou católica, então elas me convidavam para ir à igreja. Assim, depois, eles faziam reuniões, faziam comida brasileira. Isso me ajudou também, sabe? [00:08:37] E gosto da farofa, do açaí. Acho que minha mãe vai ficar com saudades do açaí. Porque, é assim, cada que nós saíamos para a rua, comíamos açaí. Comemos açaí! Então, é legal. E aprendi muita coisa. Eu acho também que algumas coisas da minha personalidade mudaram, sabe? quando eu cheguei aqui ao Brasil. Porque, eu sou uma pessoa muito séria. E, às vezes, até mal humorada. Aqui, eu achei que os brasileiros são muito positivos, vocês têm uma atitude muito positiva ante as coisas da vida. E até percebi. Porque, vocês... eu não sei... porque vocês não falam "não" primeiro. E, o resto do Latino América fala "não", quando faz uma pergunta. Então, essa possibilidade de vocês me ajudou muito, para mudar muitas coisas da minha vida. Agora, eu tenho uma atitude diferente, eu sou mais alegre, acho que isso mudou.

[00:09:55] D - É mesmo?

[00:09:56] R - E mais tranquila, sabe? Eu me estressava muito, e eu acho que não é bom. Então... e também, vocês falam muito "Você vai conseguir." Então, essa palavra, eu já deixei na minha cabeça, para lembrar sempre que eu tenha um projeto, uma atividade, uma meta para o futuro. Eu gostei muito disso, sabe? O que mais?

[00:10:23] D - E, no seu dia-a-dia, em quais situações que você está falando português e espanhol? Quando é que você fala português, quando é que você fala espanhol?

[00:10:38] R - Ah, tá. Bom, em casa, todo mundo fala espanhol, minha mãe, o tempo todo. Mas, agora, que ela vai embora, quer falar português! Eu não entendo, ela está falando um portunhol assim, e eu estou falando, "Ah, você não estudou um ano, e agora quer falar português?!" [00:10:55] para que achem que ela estudou muito, sabe? Na verdade, eu tenho amigos brasileiros. Eu consegui amigos, e eu falo com eles. Lá na associação de suboficiais tem um pessoal brasileiro, então, em cada que eu vou, falo com 
eles só português. Até... Há uma semana eu não vou para o hospital. Lá no hospital, eu também falava português. Eu deixei de ir há uma semana. A menina que eu conheci, onde eu vou morar, no Rio, que eu vou viajar para o Rio de Janeiro, ela fala português e espanhol, porque ela morou na Venezuela durante dois anos. E ela quer que eu fale espanhol para ela praticar. [00:11:40] então, eu falo, "Eu quero falar português! Então estamos..."

[00:11:44] D - Tem que dividir o tempo, né?

[00:11:45] R - Temos que dividir o tempo, porque não dá.

[00:11:47] D - Falar um pouco de português e um pouco de espanhol para...

[00:11:49] R - Isso. Pelo WhatsApp, nós falamos... ela fala espanhol e eu falo português.

[00:11:55] D - Sério?!

[00:11:56] R - E ela me corrige em algumas coisas, e eu corrijo para ela.

[00:11:59] D - Você está indo, então, para o Rio?

[00:12:02] R - Eu estou.

[00:12:03] D - Então fala um pouquinho sobre essa sua ida para o Rio, porquê que você vai para o Rio de janeiro, o que que você vai fazer lá?

[00:12:09] R - Tá. Depois do CELPE-Bras, já... agora, eu tenho a possibilidade de me apresentar nas faculdades federais, que é o que eu quero, sabe? Porque, são as faculdades acreditadas pelo MEC. Então, para ir ao Rio, a minha principal... assim... motivação é o fato de fazer o REVALIDA, para poder trabalhar aqui no Brasil, eu quero trabalhar aqui. E, além disso, quero me apresentar em Dermatologia, na UFF, na UFRJ, tem muita faculdade lá. A diferença entre o Rio e Brasília é que, em Brasília, a maioria das faculdades são para residentes. Então, é mais difícil para mim, porque ainda eu não tenho revalidação. Por enquanto, lá, eu posso me apresentar só como médico estrangeiro. Então, por isso, eu achei que minhas possibilidades eram maiores lá no Rio do que aqui. Então, era mais difícil estar viajando cada vez que tivesse uma prova, mais cansativo, sabe? 
Então achei melhor morar lá. E, graças a deus, através de um brasileiro que conheci lá na associação, tive a possibilidade de conhecer aquela menina.

[00:13:42] D - Legal. Então, você acha que... você se sente à vontade falando português já, hoje em dia?

[00:13:53] R - Sim. Na verdade, gosto muito do português. E eu fico à vontade. No começo eu ficava muito insegura, sabe? Mas, acho que já estou mais falando, gosto que me corrigem, sabe? quando eu falo errado, eu gosto. Sim, para melhorar. E, também, eu estou entendendo muito. No começo, quando meus amigos falavam piadas, eu nem entendia! Agora, eu já entendo já, pelo menos posso rir! Umas piadas, sabe? No começo, eu ficava assim, meio séria porque eu não sabia o que falavam.

[00:14:37] D - E já tem alguma situação, ou algum tema específico, que você se sente até mais à vontade falando em português? Algo que você se sinta mais livre falando em português do que em espanhol? Ou você sempre se sente melhor falando espanhol, se sente mais à vontade no espanhol?

[00:14:58] R - Assim, acho que sempre a pessoa vai se sentir mais à vontade com a língua da origem, sabe? Porque é a língua que você falou durante toda a sua vida. Mas, algumas coisas, por exemplo, se chega uma pessoa da Colômbia, eu vou ter a possibilidade, vou ter a capacidade de falar muita coisa do Brasil. Por exemplo, eu vou poder falar sobre Brasília, que é uma cidade muito linda, que tem muito árvore, que tem... às vezes, engarrafamento. Mas, porque já conheci, entendeu? Eu posso falar do céu de Brasília, posso falar que é muito lindo, eu adoro o céu daqui. Então, eu acho que lugares como tal, eu posso falar. Sobre onde pode a pessoa conhecer, onde não pode... o que é legal no Rio, por exemplo, o que é legal, em São Paulo. Porque são coisas que eu vou obtendo no percurso da minha vida aqui no Brasil. Então, nesse sentido, eu acho que a minha capacidade de falar sobre o tema, por exemplo, de lugares, de turismo, até da cultura, é maior. Da comida, das danças, dos cantores, por exemplo, eu gosto também das músicas. Entre... sabe? [00:16:31] mas na Colômbia, escutamos Vallenato... e eu gosto também das músicas daqui, sabe? E a minha mãe fala, "Não, essas músicas daqui, eu não entendo nada!" Eu falo, "Não, eu gosto." E até tento dançar, sabe? Então, é bonito, porque... eu acho que, quando... chegar a lugar... é difícil, quando você não conhece ninguém, e você... sabe? Essas pessoas falam como gringos assim. Mas, depois, você se apoderar dessa 
cultura, e tentar ser parte dela, você não vai perder as suas origens. Você vai continuar, mas pode ter a capacidade de se adaptar, de se acostumar e de viver melhor. Então, eu gosto.

[00:17:26] D - Legal. Então, você acha que a pessoa que eu conheço aqui no Brasil, falando português, é a mesma que eu conheceria lá na Colômbia, falando espanhol?

[00:17:41] R - Eu acho que não.

[00:17:43] D - Não?

[00:17:46] R - Eu acho que não, sabe? Porque, aqui falo com um sotaque diferente. Até, quando eu comecei a falar, minha mãe olhava para mim como se eu fosse outra pessoa, sabe?! Eu falo espanhol rápido, às vezes enrolado, e também, na minha personalidade, é diferente. Assim, eu trabalhava como médica, e às vezes chegava a minha consulta, o estresse, os problemas... e até lidar com as pessoas. Na Colômbia, somos pessoas muito receptivas, mas às vezes somos muito fortes na forma de falar, entre nós. E acho que aqui no Brasil, vocês em geral são pessoas que recebem bem o estrangeiro, sabe? Pelo menos essa é a minha opinião. Então, quando eu chego brava, a um lugar aqui, já aconteceu. Um shopping, por exemplo, e eu pergunto para a moça, "Quanto vale isso?" E ela... a forma de... o jeito de falar, de me tratar é diferente, e eu mudo. Essa coragem que eu venho da rua, da minha casa, não sei, muda muita coisa. E, na Colômbia, por exemplo, eu chegava num lugar, no shopping, e às vezes a pessoa era até mais grossa do que eu. Então... então, lá, as pessoas são muito... somos muito... a palavra é tipo... prevenida, aqui não sei como fala.

[00:19:25] D - Sim, sim.

[00:19:26] R - Prevenidos. Somos muito prevenidos com... com nós mesmos.

[00:19:30] D - Aham.

[00:19:33] R - Então, isso, para mim, foi interessante. Além disso, também, agora, por exemplo, eu falo algumas palavras que eu não falava antes. Por exemplo, cumprimentar ao despedir, por exemplo, 'beijo,' 'abraço.' Porque, lá, não usamos, somos muito secos para falar assim, nós só falamos "Ah, bueno, tchau. Ou Deus te abençoe," alguma coisa. 
Mas, aqui, são muito carinhosos até para se despedir, sabe? E isso são coisas que eu... he mudado, muito. Eu acho que antes, quando eu cheguei aqui, "Tchau, tchau, tchau," assim. Não, vocês cumprimentam, são... nesse sentido, eu acho muito legal.

[00:20:17] D - Legal. Está ótimo, então. Muito obrigado.

[00:20:22] R - De nada! tomara que sirva. 


\section{ENTREVISTA 2}

D - Então, primeiro, eu queria que você descrevesse o seu percurso até chegar ao Brasil. Então, eu queria que você falasse quem é você, qual a sua profissão, o que você estudou, os países que você passou, né? que você morou, quais as línguas você fala. E o porquê de você ter vindo para o Brasil. E essa diferença de como era sua vida antes, e como é sua vida aqui no Brasil.

[00:00:34] R - Ok, ok. Antes... Eu nasci na Alemanha, e sempre morei na Alemanha, até vinte e sete anos. Passei seis meses nos Estados Unidos quando eu tinha quinze anos. Nos mudamos várias vezes, na Alemanha, mas sempre na Alemanha. Sou economista, estou "boring", "aburrida", estudei economia em Berlim, meu doutorado em Berlim. Depois trabalhei como assistente na universidade, durante meu doutorado em Berlim. Depois eu fui à Namíbia, durante três anos trabalhei na Namíbia, para o Banco Central. E em Lesoto também, para o ministério de economia, fazenda... algo similar, em Lesoto. E, depois, fomos à Washington, e moramos lá oito anos, e eu trabalhei para o Banco Mundial, como economista. [00:01:54] E, trabalhei sobre África, Latino América. Brasil, não. Argentina, Uruguai, mas não no Brasil. E, o que mais? Eu aprendi... Primeira língua que eu aprendi era latim, com... onze anos, acho que, depois inglês. E, depois, porque era... eu assisti uma escola clássica, também, grega... greek.

[00:02:38] D - Grego?

[00:02:39] R - Grego antigo. Essa língua que é completamente inútil... que não precisa, no mundo. Então, eu aprendi, quase nove anos, latim, sete anos, inglês e cinco anos, grego. E também eu tentei aprender francês na escola, mas estava demais. E assim, passei seis meses nos Estados Unidos, e aprendi bastante bem o inglês lá. Depois da escola, comecei com francês na universidade, aprendi francês. E também eu precisei para trabalho em África... na África.

[00:03:31] D - E o espanhol? 
[00:03:33] R - Espanhol? Tem... Depois. Fui à Guatemala para... quatro, ou cinco semanas, para aprender... em dois mil e um? Durante meu doutorado. E tomei aulas na escola em Berlim, mas nunca usei. E, depois de... trabalhei sobre a África, e departamento do Banco Mundial, e trabalhei sobre Latino América, e então decidi aprender espanhol de novo. E, também, tínhamos a babá do Chile e com ela eu também falei muito. Mas, o francês, eu só aprendi para trabalho. Eu posso falar sobre orçamento, de dívida, tudo, tudo, tudo, mas não coisas normais, como... não sei... algo normal, eu não sei as palavras. Não consigo. Small talk, não é...

[00:04:39] D - Não consegue conversar com ninguém!

[00:04:41] R - Não. Mas, tudo... específico para finanças públicas, sim, tudo. E, espanhol, por isso, com a babá e tudo, eu posso falar. Agora não, mas, antes. Sim, eu posso falar um pouco melhor dos animais, e comida, e coisas da vida normal. E para trabalho também.

[00:05:04] D - Sim.

[00:05:06] $\mathrm{R}$ - e, as línguas, e agora, estamos aqui há, já, um ano.

[00:05:14] D - Aham. E por que que você veio para o Brasil?

[00:05:16] R - Estamos aqui porque, meu esposo, está trabalhando aqui para o Fundo Monetário. E, para mim, é um câmbio... uma mudança bastante grande porque não só é outro país, outra língua, mas também, agora, eu não trabalho. Estou começando, um pouco, mas, antes, eu sempre trabalhei todo dia, cada dia, sempre. E, agora, não. Então está muito diferente, aqui.

[00:05:49] D - É? Está ficando em casa?

[00:05:51] R - Sim, ficando em casa, com as crianças, sim. Porque, morar em outro país não é diferente, mas eu me mudei muitas vezes, diferentes continentes e tudo. Adaptar... 
acostumar-se a outro país, eu sei como fazer normalmente, mas com trabalhar, quando tem uma identidade profissional. E, se você está na casa, com as crianças, não é... para as outras pessoas, não é importante seus estudos, se tem doutorado ou não. É só que você está com as crianças. Vida profissional, não existe. Isso é difícil.

[00:06:43] D - é difícil?

[00:06:44] R - Sim. Mas não é particular... isso não é particular com o Brasil, mas com a minha vida, essa mudança. Esse, é similar em outro país. Acho que aqui é mais difícil do que em outros país, em outras formas... outras maneiras.

[00:07:05] D - E você vai continuar? Você pretende continuar aqui no Brasil, ou vocês vão passar um período determinado?

[00:07:14] R - Temos três anos aqui. Então, temos mais dois anos. E, depois, vamos voltar à Washington.

[00:07:21] D - E, quais são suas percepções do Brasil? O que que você gosta, o que que você não gosta? Quais foram aqueles estranhamentos que você teve com a língua, com a cultura, com a culinária?

[00:07:36] R - Com a língua, eu sempre quis aprender português. Porque meu marido morou aqui, e eu escutei muitas vezes ele falando português. Achei o português do Brasil uma língua muito bonita. E, então, eu sempre quis. Mas nunca pensei que eu ia ter a possibilidade de aprender. Então, essa oportunidade, para mim, é muito... eu aproveito. [00:08:04] Ah, as pessoas acham difícil... Eu sempre tenho um pouco... Acho que você precisa muito tempo para saber como um país funciona. E, também, depois de um ano, é difícil de... Eu não posso dizer que eu conheço o Brasil, eu sei como funciona. Porque, eu não gosto das pessoas que dizem, "oh, agora..." depois de dois meses, ou... não sei, oito semanas, eles sabem como a vida é. Porque, cada país tem a sua cultura, a sua história, que é difícil de compreender, para estrangeiros. Também, acho que Brasília é particular. E, para mim, tem muitas coisas que eu não gosto, de Brasília, mas pode ser que no Rio, 
ou São Paulo, ou outro estado é totalmente diferente. E eu não gosto porque acho que é muito estranho essa diferença entre ricos e pobres. E eu trabalhei muito em África, e outros países pobres, ou emergentes, mas nunca vi essa distância.

[00:09:32] D - Sério?

[00:09:33] R - Nunca. Acho que... falando com brasileiros, acho que Brasília é particular também, não? Que tem, especialmente em Lago Sul, essa escola, Escola Americana, também são pessoas que são... ricas, absurdo, não? Fim de semana, meu marido foi a um aniversário com Adrian, que tem cinco anos, né? Uma festa muito perto aqui, nesses condomínios de luxo, não? Festa enorme, muitas pessoas, e eles serviram Moët \& Chandon para os pais. Foi como quarenta, cinquenta garrafas de Moët \& Chandon. Nos Estados Unidos, é como oitenta dólares, não? Eu não sei, aqui é similar, não?

[00:10:21] D - Não tenho ideia.

[00:10:22] R - Esse champanha que está...?

[00:10:24] D - Sim.

[00:10:26] R - Mas, acho que... para mim, não é normal, aniversário de criança de cinco anos.

[00:10:30] D - Sim.

[00:10:32] R - E isso assim, pode ser que, também, é coisa da escola, que atrai mais os ricos, mas, em geral, as pessoas aqui, no Lago Sul, são muito esnobes, não? muito... Para mim, eu tenho muita dificuldade de relacionar com eles. Eu não estou parte dos grupos deles, porque eles não me aceitam como pessoa que está... como elas. Eles... são as mães, normalmente. E eu... uma vez por semana, eu vou a uma escola em Águas Lindas, e a vida é totalmente diferente lá. Acho que, essa sociedade... também essa cultura aqui, que tem empregadas, que se trata como outra... outra classe... que... 
[00:11:31] D - Com desprezo.

[00:11:33] R - Sim, como... não são pessoas, né? Não me gosta. E como eu detesto. Eu não quero que minhas crianças sabem como esses... Porque tem as crianças na escola, também, que têm babás, ou motoristas, que, para eles também, são só... Eles trabalham para a família, mas são pessoas também. E, com um salário de mil e quinhentos reais, não pode viver, não pode morar, né? num lugar como Brasília. Esse é um salário normal, para... Eu não sei... Também, as babás, em Washington, do Latino América, elas sempre disseram que não querem trabalhar para brasileiros.

[00:12:22] D - Sério?

[00:12:23] R - Os brasileiros são os piores dos... empleadores? Não...

[00:12:27] D - Empregadores?

[00:12:28] R - Sim. Que, outros países, sim, mas, Brasil...

[00:12:32] D - Nossa!

[00:12:35] R - Essa é, para mim, como... Tenho problemas com esse... com essa desigualdade, essa cultura...

[00:12:45] D - É verdade.

[00:12:48] R - Sim. Eu gosto que... Nossa vida aqui é muito bom. Nós temos jardim, temos piscina, as crianças é muito... feliz, muito contente aqui. A escola é bom, porque não é tão acadêmico, aqui, como... Os Estados Unidos, para crianças, é muito acadêmico já, de cinco, seis anos, e aqui (eu vi que) é muito mais relaxado. E o tempo aqui é bom. Muita comida. Uma pergunta sobre a culinária; acho que toda... toda a família está muito feliz com a comida aqui! 
[00:13:21] D - Está gostando?

[00:13:22] R - Muito. Adrian, a comida preferida é arroz com feijão.

[00:13:26] D - É mesmo?!

[00:13:27] R - Sim. Feijão preto, só. Feijão marrom, ele não gosta.

[00:13:31] D - Ah, é? Eu também prefiro preto.

[00:13:33] R - Sim. E churrasco, e... E tem pessoas muito simpáticas, mas tem que encontrar, tem que achar. Mas tem festas boas, churrascos. E, também, com meu marido, seu trabalho é bom, ele tem tempo para a família, e... não...

[00:13:57] D - Legal.

[00:13:58] R - Sim.

[00:13:59] D - E qual é a sua relação, então, com a língua portuguesa? Você já se sente à vontade, falando português?

[00:14:05] R - À vontade, como...?

[00:14:07] D - Já se sente bem, já... confortável.

[00:14:11] R - Depende da circunstância, assim, em geral, sim, mas tem pessoas assim, de outras partes do Brasil, que têm mais sotaque, que eu não posso compreender! Às vezes eu tenho mais problemas. Com telefone, às vezes... Telefone é mais difícil. Mas, em geral, assim... Não, eu... eu gosto muito da língua portuguesa, esta... é uma língua muito boa.

[00:14:36] D - É?

cxix 
[00:14:37] R - Sim... acho que meio me... Espanhol é um pouco mais... não sei, lógico, para mim, às vezes. É mais... o português também. É mais fácil que francês. Mas é que tem muitas exceções.

[00:15:00] D - E em quais situações você fala português no seu dia-a-dia?

[00:15:10] R - Dia-a-dia? Na escola, tenho que falar português com as professoras, com os outros pais, e com a empregada que temos. Quando vamos a essa escola em Águas Lindas, tenho que falar português com as crianças. E também com a vida normal, não? tenho que ligar para marcar consultas, ou no supermercado e todas as situações que... Agora, como eu comecei com meu trabalho, também tenho que falar português com economistas aqui.

[00:15:49] D - E já, em alguma situação, algum tema que você já está se sentindo mais à vontade, mais confortável, mais livre para se expressar em português do que em espanhol?

[00:16:05] R - Espanhol, agora, eu não posso falar demais.

[00:16:07] D - Não consegue mais falar em espanhol?

[00:16:09] R - Não, não... não. Eu tentei, e é um desastre.

[00:16:12] D - É?

[00:16:13] R - Hum.

[00:16:14] D - Está misturando muito?

[00:16:15] R - Eu não... estou pensando que... "Essa palavra é espanhol ou português?" E como... como "agora" e "ahora," és como... Não... 
[00:16:26] D - Uma confusão!

[00:16:27] R - Não, eu não... acho que, se tenho que... posso. Mas é muito difícil!

[00:16:33] D - Sim.

[00:16:35] R - Sim, e quando vamos a... As crianças, elas falam espanhol muito bem. Jakob, seis anos, com a babá, ele falava muito bem. Fomos à Washington, de navio, e... fomos a um almoço com a babá, e eles não falaram nenhuma palavra.

[00:16:55] D - Só português?

[00:16:57] R - Não, não, nada!

[00:16:59] D - Nada?!

[00:17:00] R - isso que es para mim... espanhol não é a língua nativa, e o português é tão similar que há um overlay, não? há... como... replace.

[00:17:17] D - Substituir?

[00:17:18] R - Substituiu completamente o... Porque, não... para mim, eu não posso... meu cérebro não pode compartilhar os dois... com... separar. O meu marido, ele pode fazer isso. Ele pode trocar como um minuto, português, outro, espanhol. Mas para ele português é como língua nativa, não? Eu falei com muitas pessoas, que eles não falaram em espanhol como nativo. E, para todos, é difícil. Porque, é tão similar. Se tem mais diferença, é mais fácil. Mas assim tão similar, não funciona. Inglês, sim. Alemão sim, mas...

[00:18:10] D - O espanhol não? E você acha que a língua portuguesa, que você está vivendo no Brasil, e falando português, isso mudou algo em você, como pessoa? Na sua 
forma de ver o mundo a sua volta, ao seu redor? Alguma coisa que você tenha percebido de mudança em você mesmo?

[00:18:34] R - Acho que sempre se está... não é específico para português, se estou aprendendo uma língua e não completamente como avançado com a língua, sempre a identidade é diferente, porque as pessoas querem falar com você, e não podem. E te veem... veem você como um pouco mais estúpido, ou algo assim. É sempre assim. Porque... Mas, eles não falam... Aqui, uma coisa que eu não percebi antes é que não tem muitas pessoas que falam em inglês.

[00:19:17] D - Sim.

[00:19:18] R - Então, eu tenho que tentar falar português, e eles me veem como... não veem... eles não vim... they don't see me... não. Eles não me... de ver... ver... ((risos)) Não, eles não me veem (assim), veem como... como inteligente, não?

[00:19:45] D - Sim.

[00:19:46] R - E, para mim, é muito mais difícil de me expressar como quero. Em alemão, inglês, normalmente eu falo muito, faço muitos... como brigas, muitos jokes...

[00:20:00] D - Muitas piadas.

[00:20:01] R - Piadas, e com sarcasmo, e ironic, não?

[00:20:05] D - Ironias.

[00:20:05] R - Ironia. E eu não posso, em português. Então isso, toda a minha pessoa é diferente, em português. Porque não posso expressar. Não falo muito, às vezes eu não quero ir a eventos porque eu sei que não posso participar, ou assistir como eu quero. E, também, sempre está essa conversação de "Oh, você está falando bem português; ah, não mas, é melhorar," e... é sempre como... e, me dá cinco minutos, são como... "Ah, você 
está aqui há quanto tempo?" E você... Esse destino de experts, não? Que sempre tem que explicar... Mas, toda língua... eu sempre falei muito, e rápido. Quando criança, minha amiga e eu tínhamos um clube de rápido falantes. Eu posso ler muito rápido, falar muito rápido, e... outra língua, eu não posso fazer isso como quero. Mas não é particular para português, mas para, sempre. Inglês não, inglês, eu posso fazer o mesmo que com o alemão. Mas, português... Acho que essas nuances, não? de... piada, algo... isso é muito difícil de... master, não? de saber. E, se você não pode fazer isso, as outras pessoas têm você como outra pessoa.

[00:21:50] D - Perfeito, aham. Está ótimo. Muito obrigado.

[00:21:55] R - É tudo?

[00:21:56] D - É tudo. Só isso. 


\section{ENTREVISTA 3}

D - Bom, primeiro eu gostaria que você descrevesse seu percurso até chegar ao Brasil, então falar um pouco sobre quem é você, a sua profissão, os estudos que você fez, quais países você passou, as línguas que você fala, e o porquê de ter vindo para cá, e essa diferença de como era sua vida antes e como está sendo a sua vida aqui no Brasil?

[00:00:30] R - Bom, primeiro, muito obrigado. E a primeira foi como é que eu vim para cá?

[00:00:38] D - Isso, o seu percurso, né? Contar um pouco da sua vida, para gente conhecer você.

[00:00:45] R - Bom, eu acho que isso começou quando eu tinha seis anos. Eu posso ir até lá para te contar que meu pai assistia uma novela chamada Pantanal, e... claro estava dublada na época, e eu achava curioso que ele estava grudado vendo a televisão. Eu me lembro, uma coisa que eu lembro assim, como se fosse ontem, é que eu queria ver televisão com ele. E ele não quis, ele falou: "Não, não, sai daqui, sai daqui." "Por que, pai?" "Não, é porque o programa não é para criança." Aí eu achei curioso, e deixei.

[00:01:25] D - Aham... pode continuar.

[00:01:28] R - Ah, ok. Então, uma coisa que eu achava bastante bonita era a música da novela, que era em português. Achava muito bonito como que era o som da música, isso chamou minha atenção. Depois eu cresci, aí eu vi a novela, e aí vi porque meu pai não queria que eu ficasse com ele, né? Porque tinha mulher pelada. A Cristiane Oliveira, que ainda é muito bonita, ela estava pelada na novela, então meu pai estava apaixonado, eu acho. Então assim, depois eu cresci e vi um filme: Tieta do Agreste, não a novela. E aí, quando eu escutei as pessoas falando nesse sotaque bonito, nesse linguajar nordestino, eu achei muito bonito, eu não sei te explicar porquê. E eu prestei atenção nas vogais nasais, foi a única coisa que chamou minha atenção, e achei bonito, e ainda eu acho bonito, isso, no português brasileiro. Então eu estudei Comunicação Social, numa universidade católica, eu me formei. Só que, durante a graduação, eu conheci uma brasileira que era professora de português, ainda é. Eu fui monitor dela e ela decidiu me levar para conhecer a embaixada, conhecer os professores. Me lembro que, nesse ano foi a Copa, na 
Alemanha. Aí, quando a gente estava entrando na embaixada, ela disse: "Eu te peço desculpa porque não vou falar mais espanhol. Eu vou falar português, porque minha mãe está aqui e, por um costume familiar, a gente fala português." Falei: "está." Claro, quando ela chegou e cumprimentou a mãe, as duas começaram a falar português, eu achei fantástico, pensei: "Nossa, que coisa linda!" E aí, eu acho que fiquei mais apaixonado pela língua, por esse input, de estar escutando. E eu decidi que queria estudar, nesse momento. Só que eu tive que esperar dois anos. Aí, eu comecei em dois mil e oito, fevereiro. Juliana, que é a brasileira que eu conheci, ela foi minha primeira professora. E, na primeira aula, eu me lembro muito bem que ela chegou, começou a falar em espanhol, perguntou porque que a gente queria estar na sala, aprendendo português, a única coisa que eu falei é que eu acho bonito, eu acho uma língua muito bonita. E aí, ela disse, de repente: "Bom, eu vou começar a falar português, vou falar bem devagar, qualquer dúvida que vocês tiverem, por favor levantem a mão e a gente continua." E começou a falar português. Então, foi muito bonito. Aí, eu fiz... deixa eu ver... um ano, mais ou menos, de aulas, em sala de aula. Depois, no ano seguinte, eu estudei sozinho, no YouTube, livros... na época, o agora morto MSN...? Você não conhece?

[00:04:54] D - Não.

[00:04:55] R - O Messenger.

[00:04:56] D - Ah, tá, MSN!

[00:04:57] R - MSN, é.

[00:04:58] D - Aham.

[00:04:58] R - Como é que fala, aqui no Brasil?

[00:04:59] D - MSN, aham.

[00:04:59] R - Ah bom, isso. Aí, eu conheci muita gente pela internet, muito brasileiro. Aí, eu conheci um rapaz, que é meu xará, e um professor de português aposentado, que eu acho que ele faleceu. E aí, foi muito bacana porque, com o meu xará, eu escrevia muito coisas informais, como se eu estivesse falando com um amigo. E Augusto, como era clássico, cartesiano, ortodoxo, tradicional, purista, ele odiava português coloquial. Então, 
eu escrevia alguma coisa para ele, que eu tinha aprendido com o outro, ele corrigia. Ele falava: "Esse é linguajar de pessoas iletradas, então eu recomendo que você prefira esta estrutura." E ele escrevia. Ou, de vez em quando eu escrevia e-mails para ele, comentando como é que eu tava, aí, ele escrevia, respondia, aí ele colocava depois: "Meu caro, eu me dei a liberdade de corrigir seu texto. Então segue a correção, se tiver alguma pergunta, você me escreve, e a gente discute." Aí corrigia, ele colocava em vermelho, fazia um código de cores, ele era muito didático. E, qualquer dúvida que eu tinha, eu perguntava a ele. E ele respondia, ele explicava porquê, e ele recomendava: "Recomendo que você leia isso, leia aquilo," e pronto. Bom, foi assim que eu acho que eu tive os primeiros contatos sérios com o português. Depois, eu fui... Como é que foi? Eu já era professor na universidade, e eu fiz uma substituição no centro cultural. Durante um mês... Eu não falava português, mas a diretora me chamou para dar aula, e eu achei o primeiro grande desafio da minha vida. Então, dei aula durante um mês. E essas coisas somente foram fortalecendo o vínculo que eu tenho com português. Então, depois desse mês... Eu amei a experiência, decidi que eu queria trabalhar com o ensino de português, e depois teve o concurso, graças a deus eu passei, trabalhei lá durante três anos, e eu senti uma necessidade de ter uma formação na área. Então, foi por isso que, sem conhecer ninguém, sem saber o que eu ia fazer, eu pedi demissão do meu emprego, que eu trabalhava na embaixada do Brasil em El Salvador. Pedi demissão, falei para minha mãe: "Eu não sei proncovô, mas eu vou tentar fazer mestrado." Aí, assim que eu vim para cá, por uma necessidade pessoal de ter uma formação na língua portuguesa.

[00:07:49] D - Perfeito, excelente, excelente. E, então, você pretende continuar no Brasil, ou, você pensa em passar um período determinado aqui, voltar para El Salvador?

[00:08:00] R - Eu não sei se eu voltaria para El Salvador, o que eu sei é que eu quero trabalhar com português. Então... é uma parte que eu não consigo mais dissociar, isso está fora de cogitação. Pode ser em outro país, por que não? Pode ser na Argentina, pode ser no Uruguai, pode ser na Costa Rica. No meu país, eu não sei, porque... não sei, acho que não... Como é que eu posso te falar? Eu acho que eu me descobri muito no Brasil. Então, acho que, voltando ao meu país, seria como... Não sei, regredir? Não sei. Acho que não. Mas, se eu pudesse, eu moraria no Brasil, com certeza. 
[00:08:42] D - Muito bom. E quais são suas percepções do Brasil? O que você gosta, o que você não gosta? Quais os estranhamentos que você teve com a língua, com a cultura, com a culinária, com as pessoas?

[00:08:55] R - Bom, culinária, nada. Eu acho a culinária brasileira muito melhor. Então, isso está perfeito. Com a língua eu acho, e eu falo hoje em dia, que eu aprendi português aqui.

D - Não, tranquilo.

[00:09:12] R - Por quê? Porque você aprende... fora do Brasil, você aprende o que está no livro, e você tem pouco insumo autêntico. Talvez no YouTube, um texto mais atual. Mas, o português vivo, que se fala aqui no Brasil, somente está no Brasil. Então, quando eu vim para cá, eu escutei nuances de pronúncia, de vocabulário, de gírias novas, de expressões vivas, puras do Brasil. Aí, eu posso falar que já circulo mais na língua. Mas assim... É, é isso. Estranhamento com a cultura? Não, é bem parecida com a minha.

[00:09:59] D - É?

[00:10:00] R - É. Só que assim, eu... Deixa eu ver... Não. É que assim, eu nunca morei fora de casa. Então, eu tive muito problema aqui no Brasil, de relações, relacionamentos pessoais, de amigos, amorosos. Então, eu não sei se teria acontecido a mesma coisa lá.

[00:10:23] D - Entendi.

[00:10:25] R - Não sei se é uma questão de maturidade, de você crescer fora de casa, da proteção da sua mãe, ou é uma questão própria do Brasil, o que eu acho que não. Então, eu não sei, eu não posso te falar se é porque eu estou no Brasil, ou é porque eu saí de casa, não sei. Mas eu acho que sim, o Brasil de alguma forma me fez amadurecer, então isso é bom.

[00:10:49] D - E qual sua relação com a língua portuguesa...

[00:10:51] R - Ah, peraí, peraí, peraí! Falta, falta.

[00:10:52] D - Falta? ((risos)) 
[00:10:53] R - Eu nunca, nunca imaginei que no Brasil existisse homofobia e racismo, nunca.

[00:11:02] D - É mesmo?

[00:11:03] R - Nunca. Até porque vocês vendem uma imagem diferente, e, até, eu falava isso em sala de aula: "O Brasil é um país muito aberto, de braços abertos, aceita tudo, tolera tudo," e não é.

[00:11:20] D - E você descobriu que não é...

R - Que não é.

[00:11:22] D - Que somos muito conservadores?

R - Ainda: preconceituosos, homofóbicos. Mas, todo o mundo é. Então... o meu país é muito mais. Então, é interessante... É, é difícil você entrar no Brasil e você ver isso, mas é normal, é o que acontece no mundo todo. Só que vocês vendem uma imagem diferente. Mas... mas, é isso.

[00:11:51] D - Perfeito.

$\mathrm{R}$ - Todo o mundo é assim.

[00:11:52] D - Excelente. E qual é a sua relação com a língua portuguesa? Você se sente, falando, à vontade? A gente vê que seu nível de português é excelente.

$\mathrm{R}$ - Muito obrigado. Eu acho que não, mas obrigado.

[00:12:05] D - E você se sente totalmente à vontade dentro da língua?

$\mathrm{R}$ - Eu conversava com minha orientadora, que ela é casada com um brasileiro que fala francês, e ela dizia: "Eu nunca vi alguém usufruindo uma língua estrangeira." Aí eu falei, "Como assim, professora?" "Não, que, por exemplo, você seria o segundo caso, que eu vi na minha vida. Quando meu esposo fala francês, eu percebo que ele desfruta cada palavra. Ele está curtindo a pronúncia, ele acha o máximo poder se comunicar. E você também é desse jeito, eu percebo que você gosta da língua portuguesa." Aí, eu falei para ela: "Eu 
não gosto, eu amo o português." Não é uma questão de gostar, acho que vai muito além. E, por exemplo, eu vou te contar poucas coisas porque, aí, eu não quero tirar teu tempo. [00:13:01] Meu cartão foi clonado, semana retrasada. Aí, eu liguei, fiz o bloqueio, liguei, falei com dois atendentes, expliquei tudo. Claro, eu tava chateado. Mas, eu tava comentando com um amigo, e eu comecei a rir. E ele falou: "Você está rindo por quê?" Aí, eu falei para ele: "Porque eu fiz isso em português!" E ele: "O que que tem?" "Cara, é muito complicado você fazer noutra língua." Então... Ou, por exemplo, eu tive um problema também, eu fui expulso do apartamento onde eu morava. Eu tava muito irritado, muito irritado, e eu comentei também para esse meu amigo o que aconteceu, e depois eu comecei a rir. E ele: "O que que está acontecendo com você rapaz?" Aí, (ele): "Rapaz, eu estou irritado, eu estou num nível muito alto de tensão, e eu consigo te contar em português." ((risos)) Claro, ele não dimensiona isso, porque ele não fala outra língua... eu falo um pouco de inglês também, espanhol e português. Então, eu sei o que é tentar explicar o mundo em outra língua. Então, é muito complicado, é complexo, é complexo demais. E, para mim, isso é delicioso, você poder fazer coisas que você naturalmente faria na sua língua mãe. Portanto você circula de uma forma tal, que também é permitido você fazer isso em outra língua. Isso é gostoso, rapaz.

[00:14:37] D - É, demais, né?

R - É. Então, além disso, ainda eu não consigo explicar qual é a paixão pelo português. Eu não sei, mas tenho. Então... Como eu te falei, eu... agora, eu não concebo a minha vida profissional e pessoal fora do português, por exemplo. É isso.

D - Excelente.

R - Obrigado.

[00:15:01] D - E, no seu dia-a-dia, você fala português e espanhol em quais situações?

$\mathrm{R}$ - Eu vou te confessar um pecado, eu evito falar espanhol. Eu falo com uma amiga, que é argentina, mas porque a gente construiu a relação em espanhol. Mas, quando eu dou aula para hispano-falante, eles querem falar em espanhol depois da aula, eu não quero, eu não falo. [00:15:28] Aí, eles: "Profesor, usted habla espanhol. ¿Por qué no habla con nosotros?)" Aí, eu falo: "Não, não quero. Porque você está aprendendo português." Então, 
eu evito, eu evito falar em espanhol. É claro que eu falo com minha família, e com minha amiga, mas eu tento evitar. Até porque eu penso que eu estou aqui para melhorar, pronúncia, vocabulário. Então, por isso eu estou falando mais português. É isso.

[00:15:54] D - Ótimo. E existe alguma situação, algum tema específico que você se sente mais à vontade, mais livre para se expressar em português do que em espanhol?

$\mathrm{R}$ - Eu acho que sim. Bom, o Brasil significa muito para mim, em termos de crescimento profissional, pessoal. E, principalmente, pessoal, de alguma forma. Por quê? Porque eu saí de casa, e eu vim ao Brasil sozinho. Então, eu tive que me virar muitas vezes. E eu acho que isso me deu certa emancipação, de alguma forma. E isso também foi até níveis íntimos, pessoais, de eu me aceitar totalmente como homossexual, e falar abertamente disso, eu comentar com as pessoas. E, do nada, eu, sem pensar, sem preparar nada, eu já chego falando que sou gay. Porque, para mim, não tem problema. E falar isso em português também é gostoso! Então, eu acho que eu me sinto mais livre em algumas coisas que eu, talvez, não falaria em espanhol. Falar, por exemplo, a minha preferência sexual, falar de coisas que eu quero, que eu não quero, e, sim, eu acho que eu faço isso mais em português, do que em espanhol. Curioso, eu não sei. Mas, é.

[00:17:23] D - Excelente. Então, você acha que a pessoa que eu conheço aqui no Brasil, falando português, é uma mesma pessoa? Ou é outra pessoa, daquela que eu conheceria em El Salvador, falando em espanhol?

R - Você sabe que a última vez que eu fui, minha mãe falou para mim, "Você mudou."

[00:17:45] D - Sério?

R - É. E eu acho que uma língua te faz isso, você vê a vida diferente. Porque você circula noutro ambiente, e você se adapta de uma forma tal, que você identifica aquele mundo como seu. Então, eu... eu não me acho brasileiro nem um pouco, eu sei que eu sou diferente, eu sei que eu sou estrangeiro. Mas, eu tento policiar minha pronúncia, para não ser apontado por aí, para não ser catalogado como o outro pelo meu jeito de falar. É por isso que eu tento me policiar com a pronúncia. Mas, eu não me sinto brasileiro, eu não... nem um pouco. Eu reivindico, muitas vezes, meu papel de estrangeiro, mas o português e o Brasil me mudaram de uma forma positiva, eu acho. Com certeza, a pessoa que estava 
lá, há três anos, em El Salvador era mais inibida, era mais calada, não falava o que sentia, e, agora, o português me deu isso, me deu essa chance de eu falar o que eu sinto, o que eu quero, o que eu penso e das coisas que eu gosto. Eu acho.

[00:19:03] D - Que ótimo. Muitíssimo obrigado!

$\mathrm{R}$ - Eu que agradeço, obrigado. 


\section{ENTREVISTA 4}

D - Bom, eu gostaria que você descrevesse o seu percurso até chegar ao Brasil. Quem você é, sua profissão, os estudos que você fez, os países pelos quais você passou, o porquê de você ter vindo para o Brasil e como que era a sua vida antes, e como é a sua vida aqui.

[00:00:25] R - Tá. Eu sou de nacionalidade chilena, minha graduação foi em Engenharia Ambiental, fiz parte dessa graduação nos Estados Unidos, onde morei um tempo. Ao terminar minha graduação, eu fiz meu mestrado na Suécia, mestrado em engenharia, e lá começou minha carreira de pesquisador. Durante esse período do mestrado, eu tive a oportunidade de participar de um grupo de pesquisa da Universidade de Tóquio, e aí fiz o doutorado lá, no futuro fui fazer minha tese de doutorado. No Japão, eu fiquei quatro anos e meio. Durante esse tempo, eu fui a um intercâmbio em duas universidades, que foi o Instituto Tecnológico de Massachusetts, em Boston, e a Universidade Tecnológica de Zurich. O intercâmbio, a razão dele foi o motivo de minha pesquisa, que tinha uns casos de estudo, que precisava, para minha pesquisa de doutorado, então eu fui para lá e fiquei uns meses. Eu fui para lá, mas foi assim, tive o apoio do ministério da economia e educação japonês, então tinha bastante dinheiro para fazer esse tipo de triagem e pesquisa. Durante esse período também, eu participei bastante em associação de sustentabilidade, onde fui parte dos diretores. Esse grupo sustentabilidade era representante de seis universidades, que tava o MIT, o Instituto tecnológico de Zurich, Instituto tecnológico da Tailândia e outras universidades. Depois que eu terminei o doutorado, foi no ano de dois mil e sete, eu decidi voltar para o Chile, eu dei aula por um semestre e foi a primeira vez que vine para o Brasil. Fiquei em São Paulo oito meses, trabalhando em consultoria. Mas, o meu início da relação com o Brasil, o motivo dela foi por minha futura esposa. Os pais dela moravam em São Paulo, então a gente decidiu ir para lá, eu me casei, né? nesse período, com ela, e poderia falar que esse foi o motivo principal, eu não tinha... Eu não tinha muito conhecimento do Brasil, [00:03:16] foi a primeira vez que fiquei lá, o mercado laboral não é fácil, que eu sou engenheiro, né? Bom, e fica limitado a fazer consultoria, ou acadêmico. Quando eu tava... eu tava) um mês, eu recebi uma oferta para trabalhar nos Estados Unidos, no Banco Interamericano. Aí, eu decidi tomar essa oferta e fiquei trabalhando até o dois mil e catorze. Aí, lá, trabalhei em projetos de saneamento, na minha área, para toda a Latino América e o Caribe. Era um trabalho mais focalizando engenharia, né? Aplicar mesmo e não precisava ter um conhecimento do doutorado, mas 
ter outro tipo de conhecimento mais prático. Conheci as realidades de diferentes países, viajei bastante. Era um bom trabalho, mas o estresse era alto. Aí, por motivos familiares, a gente decidiu voltar para o Brasil, e estou morando em Brasília, desde dois mil e catorze, onde eu trabalho como professor e pesquisador aqui na UnB. Agora, o relacionamento com o Brasil evoluiu um pouco, né? é um trabalho mais estáveble, né? Mas também tenho um neném, então não dá muito tempo para pensar todas as coisas, né? Então, é o dia a dia, batalha do dia-a-dia.

[00:04:54] D - Perfeito. E você pretende continuar aqui no Brasil, ou vocês estão aqui por um período determinado?

[00:05:03] R - Então, isso é minha dúvida. Você não é a primeira pessoa que pergunta. Na média, a gente fica de três a quatro anos no país, então não sei se em Brasília, vai ficar muito tempo não, e depende das condições laborales, né? Eu queria ter a oportunidade de ir a morar no Chile, como família. Então, ainda to vendo essa opção. Mas tudo vai depender do trabalho mesmo, né? se vai ter algum trabalho ou não. Por agora a gente está estável, mas ninguém sabe.

[00:05:41] D - E seu filho é brasileiro?

[00:05:43] R - Ele é brasileiro sim.

[00:05:44] D - Muito bom. Quais são suas percepções do Brasil? O que que você gosta aqui, o que que você não gosta, quais foram aqueles estranhamentos que você teve com a língua portuguesa, com a cultura, com a culinária?

[00:06:03] R - Bom, eu acho que a parte interessante do país é a... o sentimento das pessoas, que é fácil comunicar-se com elas, né? é fácil realizar um tipo de amistad, né? Posso falar que mais próximo ao Latino América que... o resto dos países que já morei. A comida também é similar. Assim, mas também tenía um outro aspecto que eu achei interessante, que, em meu caso, era um dos poucos países aqui no continente que tinha uma forte influência japonesa, que, no Chile, não tem. Então, foi como possibilidade de ficar mais perto do Japão, mas não indo morar no Japão, né? só foi um plus. Coisa ruim? Ah, bom, como todo país, tem seus aspectos errados, né? Como disse, acho que a violência, né? que o nível de crimes... criminosidade das pessoas é alto, da sociedade, né? 
[00:07:30] Talvez seja porque o país é grande mesmo, né? [00:07:33] E as ferramentas que as prefeituras têm não é suficiente. Mas é um tema mais político, né? como estrangeiro, é difícil avaliar isso. Interessante para mim foi ver essa diferença entre o Sul do Brasil e o Norte do Brasil, né? [00:07:52] Em términos de infraestrutura, mas também entre a distribuição populacional, do tipo de pessoas também, né? do comportamento delas. Minha esposa é do Rio Grande do Sul, de Porto Alegre, então eu tive a oportunidade de viajar para lá, e acho que é outro Brasil, mesmo, comparado com Centro-Norte, ou Nordeste. Isso, eu acho que existe esse tipo de distinção. [00:08:18] O meu país é diferente, né? O Chile é um país com governo centralizado, e aqui é estadual, né? então, cada qual tem sua identidade.

[00:08:36] D - E com o português, com a língua portuguesa?

[00:08:39] R - Bom, isso é... isso é mais... entra numa área mais cinza, né? porque, quando eu conheci a minha esposa, foi em dois mil e três, eu já conhecia brasileiros, então, de certo modo, eu tentei comunicar-me com eles, então, desde dois mil e três, para aqui já estava tentando falar um tipo de português, né? [00:09:08] Português errado, com certeza. Mas, aumentou o vocabulário, né? viendo tudo isso. Eu acho que isso ajudou, né? A grande diferença é que agora eu decidi pegar aulas, então estou vendo quales são as fundamentações que trate de tudo que eu falava, né? (e quais são) os aspectos errados. Então, eu acho que, nesse sentido, pegar aulas aqui na UnB foi positivo. Acontece bastante com hispano-falante, que acha que porque a língua é parecida, né? as palavras são parecidas, a pessoa não se dá o tempo de estudar (mesmo, né?) E aí cai nesse erro, né? Então, no final das contas, talvez um estrangeiro que não seja hispano-falante acaba falando melhor português que o hispano-falante, pela preguiça dele, de não fazer o esforço, né? [00:10:03] E eu já vi bastante esse exemplo em São Paulo, né? o pessoal da Croácia falando um português melhor que um hispano-falante, né? Não, sem comparar o meu, porque o meu já era errado mesmo, né? [00:10:17] o resto dá para ver, né? Quando ando na cidade, eu comparava, né? Nossa, ele fala muito bem, a língua dele não é baseada no latim, e é interessante esse tipo de esforço que essa pessoa... hã... não sei, no dia-a-dia melhorou.

[00:10:38] D - Mas você se sente à vontade falando português? Qual é a sua relação com a língua também? Em casa, com a sua esposa, com filho? 
[00:10:47] R - Bom, em casa é mistura, né? Em casa fala mais uma mistura de japonês com inglês... e português, né? Porque, no fim das contas, tem muitas formas de expressar português, que eu fico mais à vontade em inglês, ou japonês. [00:11:05] Então, aí, como que necessito ações mudam, né? Caso particular, como eu dou aula na UnB, tinha que melhorar minha base do português, né? Porque a maioria das aulas são em português, então aí tive um esforço a mais. Então, nesse sentido ha sido um pouco mais dificultoso, mas sempre uma ganância no futuro, né? que você vai recolher daqui a cinco anos [00:11:35] então é um esforço que é melhor fazer agora que después.

[00:11:40] D - Então, no seu dia-a-dia, você fala mais português dentro de sala de aula?

[00:11:44] R - Exatamente. Acho que, em casa, não. Não, não.

[00:11:48] D - Não, né? E tem alguma situação, algum tema específico que você já se sente mais livre, mais à vontade para se expressar em português? Do que em espanhol, ou inglês, ou japonês? Ou sempre o português ainda é aquela língua que está mais distante para você?

[00:12:10] $\mathrm{R}$ - Eu acho que em término de pesquisa é o inglês, sempre vai ser o inglês, né? [00:12:15] toda a pós-graduação fiz em inglês, tem muito tema que eu não sei o equivalente, ou não é tão rápido, tener o equivalente, quando falo ou em português, ou em espanhol, o mesmo caso, né? O dia-a-dia... eu acho que é... que é misto, no sentido que é... talvez sem ter a intenção, eu misturo português com espanhol, quando estou intentando falar espanhol, né? Caso, foi agora, que fui de férias, para Chile, eu misturei, sendo que eu sou hispano-falante, né? Também, pode ser o caso que eu morei tanto tempo fora que é difícil, né? Somente falo espanhol quando tenho a oportunidade de fazer um videoconferência com meus pais ou alguma das minhas irmãs, mas o resto é em inglês. Então, o uso da língua espanhola mesmo disminuiu bastante. Então, é raro, né? em vez de misturar, quando eu estou falando português, com espanhol, faço do outro modo. Então, o pessoal lá agora ficava olhando quando eu falava qualquer coisa, né?

[00:13:39] D - Estava parecendo estrangeiro também!

[00:13:42] R - Então. Não, (teve um pessoal que) já perguntou. Eu fui fazer fazer uma papelada no ministério... havia uma moça do Chile, né? eu perguntei para ela, ela tem um 
filhinho, né? qual que é o nome do filhinho. A gente ficou falando, e ela perguntou para mim se eu era estrangeiro. Aí eu fiquei sem jeito, né? "Ah... não." Então, o problema é esse.

[00:14:03] D - Bom, e você acha que a língua portuguesa mudou alguma coisa em você, ou na sua forma de ver a realidade ao seu redor? Essa convivência no Brasil, a sua esposa ser brasileira, isso te mudou também?

[00:14:24] R - Bom, a inserção de uma língua, a introdução da língua na pessoa sempre vai gerar um tipo de mudança, né? Mi caso, no meu caso, é uma mistura, né? Porque eu tive a oportunidade de morar em diferentes lugares, tem um tipo de... de influência, né? Talvez... penso que, quando eu falo português, eu tento ser mais simpático do que em espanhol e inglês. $\mathrm{O}$ inglês, eu sou mais seco, em espanhol também. Então... também tem que ver com o tipo de pessoas que eu falei em português. Bom, no ano anterior, nunca trabalhei ou nunca utilizei o português no trabalho mismo, então era o dia-a-dia que o tipo de conversa era diferente, né? também em casa. Mas, quando você trabalha, muda, né? Então, às vezes fico com a dúvida se está forte quando falo português, porque aí você não sabe se está falando muito forte ou não. Então, aí eu diminuo, principalmente com os estudantes. Então... é, mais ou menos. O resto, eu não saberia definir a mais que isso, no dia-a-dia.

[00:16:05] D - Então, você acha que existe uma diferença...

[00:16:08] R - No comportamento, exatamente.

[00:16:10] D - Claro, claro. Da pessoa que eu conheço aqui no Brasil, falando português, daquela que eu conheceria no Chile, ou nos Estados Unidos ou no Japão? Você acha que eu teria uma percepção diferente de você?

[00:16:22] R - É, diferente. Porque, a cultura também, a cultura do país faz responder diferente, né? O Estados Unidos, lá é competitivo, personalista, então você tem que ser forte. [00:16:33] No Japão tem a jerarquia. Então, você muda a forma de falar, de comportar-se. No Brasil é mais aberto. No Chile, eu acho que tem que ver também, a influência, também do que é o grau da pessoa, né? No sentido, o grau de profissão, né? [00:16:55] algo é esperado que uma pessoa com doutorado e com anos de experiência 
tenha certo tipo de comportamento, né? Que não pode ser tão amistoso, ou aberto para hablar, né? que dá uma certa liberdade. Porque, eu não sei se estou muito puxando o [00:17:21] indo ao extremo quando falo português, né? Aí, os limites ainda não estão muito claros.

[00:17:29] D - Perfeito. Muitíssimo obrigado, pela sua colaboração.

\section{ENTREVISTA 5}

D - Bom, então eu gostaria que você descrevesse um pouco o seu percurso até chegar ao Brasil, então falar um pouco sobre quem você é, qual é sua profissão, os estudos que você fez, os países pelos quais passou, as línguas que fala e o porquê de ter vindo aqui para o Brasil. E a diferença da sua vida, né? antes e agora, aqui no Brasil.

[00:00:25] R - Está bom. Minha vida, minha realidade, eu já passei várias vezes pelo Brasil, não é a primeira vez que estou aqui. Tudo começa em mil novecentos e setenta e oito, quando minha família, nós somos uma família de alemães, chegaram aqui pelo emprego do meu pai, meus pais, naquela época, não tinham nenhuma relação com o Brasil. Eu cheguei aqui ao Brasil aos três anos de idade e passei sete anos morando em Belo Horizonte. Uma família de alemães, mas eu acho que a minha socialização, a minha alfabetização, tudo isso aconteceu num contexto brasileiro. Naquela época, não tinha escola internacional, nada disso, então eu fui realmente socializado e alfabetizado no contexto brasileiro. Passei aqui uns sete anos morando lá, e aí a gente voltou para Alemanha. Depois passou um tempo na Alemanha, voltamos à América do Sul, mas, naquela época, pra Bolívia. E aí, eu terminei meus estudos da escola na Bolívia, voltei para a Alemanha e me formei de economista. Saindo da faculdade, eu comecei a trabalhar para uma instituição financeira internacional, de economista, e esse trabalho me levou de volta à região. Trabalhei sobre o Brasil, trabalhei sobre a Bolívia, outros países da América Latina. E, enfim, dois anos atrás surgiu a possibilidade de trabalhar aqui no Brasil, cheguei aqui um ano e meio atrás, e estou agora aqui, trabalhando como economista no país. Eu tenho uma certa proximidade às línguas latinas, por ter passado pelo Brasil e pela Bolívia, eu falo espanhol, falo português. Eu também fiz meu doutorado na Itália, onde eu aprendi a falar italiano, eu, também, tive francês na escola, então esse grupo de línguas é uma área onde eu me sinto bastante confortável, diria eu.

[00:02:49] D - Muito bom. Então, você vai ficar um período determinado no Brasil? Você não veio para morar aqui, sem...? 
R - Não. Não... Não estamos aqui para morar para sempre, eu acho que estamos vendo um período de três anos, quatro anos, que vamos morar aqui no Brasil.

[00:03:08] D - Legal. E quais são suas percepções do Brasil? O que que você gosta, o que que você não gosta, quais os estranhamentos que você teve com a língua portuguesa, com a cultura brasileira, com a culinária?

$\mathrm{R}$ - Voltando ao Brasil, depois de muitos anos, eu percebi que eu reconhecia muitos traços da sociedade, muitas características, então eu tive poucos momentos nos quais eu fiquei surpreendido. Tudo era de uma certa forma conhecido, mas isso foi... e, também, vendo minha família, que não é brasileira, se surpreendeu um pouco mais, houve situações nas quais eu entendia as pessoas, as formas de ser, a cultura, e eles não. E foi aí, que eu percebi mais uma vez que eu, por ter passado a infância aqui no Brasil, eu tenho uma certa facilidade de entender. O que que eu gosto? Eu gosto da espontaneidade das pessoas, da alegria, são dois traços, acho muito importantes aqui no Brasil.

[00:04:25] D - Muito bom. E o que você não gosta?

R - É uma sociedade que ainda está em transformação, e uma parte dessa transformação acho que é a desigualdade. Eu acho que tem um grupo de pessoas que está tendo uma vida muito boa no Brasil, mas uma grande parte de pessoas que ainda está no processo de aumentar renda, e de aumentar as possibilidades de educação para as famílias, tem muitos problemas de saúde, do sistema de saúde. Então é essa percepção de divergência e de desigualdade que é um tema que eu vejo com uma certa preocupação, e que eu gostaria de ver mais progresso.

[00:05:18] D - Perfeito. Em quais situações que você costuma falar português ou espanhol no seu dia?

R - A maior parte do meu dia eu falo português, eu falo por razões de trabalho. Eu trabalho muito com o Governo do Brasil, tanto no Banco Central como no Ministério da Fazenda, então aí, eu falo muito português. Também, aqui no escritório, meus colegas são brasileiros, então eu costumo falar português. Então, é mais no âmbito profissional, eu diria. Espanhol, também. Eu também sou representante para a Bolívia, então uma certa 
parte do meu trabalho é uma interação também com o pessoal de lá, na Bolívia, aí, é onde eu falo espanhol. Mas, de novo, é no âmbito profissional.

[00:06:13] D - E, em casa, o que que você fala?

R - Em casa, sendo uma família de alemães, eu só falo alemão. Às vezes, com meus filhos, agora, eu começo a falar português, porque eles chegam da escola e me contam piadas em português, me perguntam: "Pai, o que que é isso? O que é, o que é?" Aí, a gente entra naquelas brincadeiras, e daí eu falo português com eles. Mas assim, conversas mais sérias na casa, com as crianças, com minha esposa é sempre em alemão.

[00:06:40] D - Perfeito. E existe alguma situação, algum tema específico que você se sente já mais à vontade, você se sente mais livre, às vezes, para se expressar em português?

$\mathrm{R}$ - Eu diria que, com minha família, sempre será em alemão. Eu acho que, aí, o fato do alemão ser a nossa língua principal em casa, sempre me vai colocar nessa situação. Agora, falando com amigos, assim... eu não diria mais à vontade, mas eu diria que tem situações que tanto faz, para mim, falar português ou alemão.

D - Ah, sim?

$\mathrm{R}-\mathrm{E}$.

[00:07:20] D - Você sente o português bem seu? Não sente como estrangeira?

R - Sinto, sinto. Não é uma língua onde eu tenho... eu começo a pensar como é que fala. Eu sei que não é perfeito, mas eu também não tenho esse bloqueio na cabeça de como é que eu vou terminar essa frase não. Eu começo e de alguma forma eu vou terminar.

[00:07:40] D - Legal.

$\mathrm{R}$ - O que eu não tenho tanto no espanhol. Talvez eu poderia acrescentar isso, que, no espanhol, foi uma língua que eu aprendi aos catorze, quinze anos, e aí, às vezes eu preciso pensar um pouco mais, assim. Eu tenho essa conexão direta com o português... menos do que com o alemão, mas eu tenho essa com português. Com espanhol, talvez um pouco menos. 
[00:08:03] D - Uhum. E com o inglês?

R - É, com o inglês também.

D - Também?

R - É.

[00:08:08] D - Perfeito. Então, você se sente mais à vontade com português do que em espanhol?

$\mathrm{R}$ - Um pouco sim, sim.

D - Sente?

R - Sim.

[00:08:15] D - Interessante.

$\mathrm{R}$ - No profissional, eu acho que não há diferença. Mas, naquela conversa casual, aí, eu acho que sim.

[00:08:25] D - E você acha que a língua portuguesa mudou alguma coisa em você? Por você ter vivido aqui tão cedo, você acha que a forma como você vê a realidade, o mundo, é diferente por causa do Brasil e da língua portuguesa?

$\mathrm{R}$ - Certamente, certamente. Eu acho que... Bom, eu mesmo percebo que eu me comporto de uma forma diferente, quando eu falo português ou alemão. Eu acho que eu sou mais expressivo, eu uso... a entonização da língua é diferente. Eu até acho que eu gesticulo... mais quando eu falo português. Mas, também, alemão é uma língua muito... como eu diria? Muito clara. É difícil expressar uma situação na qual você não quer tomar uma posição firme, porque... Eu acho que em português é mais fácil, em português você pode dar uma entonação de talvez isso, talvez aquilo, que dá um jeito que talvez é um pouco mais difícil ser expressado em alemão. Isso tem que ver com a língua, mas, claramente, também com a mentalidade das pessoas. E, nesse sentido, eu acho que ter aprendido o português de infância aqui no Brasil também influenciou minha percepção e minha identidade. 
[00:09:57] D - Claro. Então...

$\mathrm{R}$ - O que me facilita a vida aqui, mas, também, é uma... é uma fonte de... eu não diria conflitos, mas de situações, no contexto alemão, que são diferentes, né? Quando a expectativa da outra pessoa é de um posicionamento claro, pode gerar um conflito.

[00:10:25] D - Então eu te conhecendo aqui, falando português, e te conhecendo na Alemanha, falando alemão, você acha que eu teria duas percepções de você?

$\mathrm{R}$ - Eu gostaria mais de ver uma percepção com duas... ((risos))

D - Com duas vertentes?

$\mathrm{R}$ - Com duas vertentes, sim.

[00:10:44] D - Perfeito.

$\mathrm{R}$ - Porque isso ajuda. Assim, comunicação é mais do que só falar uma língua, tem vários níveis dessa comunicação, e eu acho que para levar essa comunicação ao sucesso é importante fazer essas pontes além da própria língua. Eu acho que, nesse caso, eu tenho habilidade de conversar, de me comunicar com o brasileiro e me comunicar com o alemão.

[00:11:18] D - Perfeito. E em espanhol?

R - Bueno. ((risos)) Como te digo, yo llegué a Bolívia a los quince años. No hablaba español, pero entré en una escuela donde el idioma social era el español, entonces, sí aprendí a hablar el español, y yo creo que por el hecho de que trabajo en el ámbito español y también en el ámbito portugués yo puedo hacer la diferencia entre los idiomas. A veces me cuesta un poco, como en situaciones como esta ir de uno al otro, pero después de dos, tres días en un contexto español ya me siento más seguro en hablar español.

D - Y cómo ves la diferencia cuando hablas portugués? Crees que hay una diferencia?

$\mathrm{R}$ - Mira. Te cuento que al hablar español, la variación de españoles que uno tiene en la América Latina, en la América central y en España es muy grande. Y en los últimos años yo viví con gente de España, yo trabajé mucho con gente de Latinoamérica, de diversos 
países, y una cosa que noté, que no tengo tanto en portugués, pero la veo en español, es que yo me acerco mucho al acento que tiene otra persona. Así, si me escuchas hablando con un argentino, después de un tiempo yo voy imitando al argentino, cuando paso dos días en Bolívia, ya voy a hablar como boliviano. Yo no sé porque. No me gusta. Quisiera tener una versión propia de mi español, pero veo que me acerco a la forma como habla la otra persona habla español. Es muy raro ((risos)). Y la persona piensa que la estoy imitando, pues llega uno, empieza a hablar como boliviano y termina hablando como argentino. O sea, es algo que todavía estoy buscando tener un español propio mío, pero como la diferencia de españoles que encuentras en América Latina, entre chileno y argentino, boliviano y colombiano, ni hablando del mexicano, es tan grande, a veces me cuesta situarme y definir cúal es mi forma de hablar español.

D - Perfecto, muchísimas gracias, muítissimo obrigado. 